Prepared in cooperation with The Nature Conservancy and the U.S. Army Corps of Engineers

\title{
Monitoring Framework for Evaluating Hydrogeomorphic and Vegetation Responses to Environmental Flows in the Middle Fork Willamette, McKenzie, and Santiam River Basins, Oregon
}

Open-File Report 2018-1157 
Cover: Photograph of Dexter Dam, Middle Fork Willamette River, Oregon. Photograph by J.R. Wallick, U.S. Geological Survey, October 20, 2017. 


\section{Monitoring Framework for Evaluating Hydrogeomorphic and Vegetation Responses to Environmental Flows in the Middle Fork Willamette, McKenzie, and Santiam River Basins, Oregon}

By J. Rose Wallick, Leslie B. Bach, Mackenzie K. Keith, Melissa Olson, Joseph F. Mangano, and Krista L. Jones

Prepared in cooperation with The Nature Conservancy and the U.S. Army Corps of Engineers

Open-File Report 2018-1157 


\title{
U.S. Department of the Interior \\ RYAN K. ZINKE, Secretary
}

\author{
U.S. Geological Survey \\ James F. Reilly II, Director
}

U.S. Geological Survey, Reston, Virginia: 2018

For more information on the USGS - the Federal source for science about the Earth, its natural and living resources, natural hazards, and the environment-visit https://www.usgs.gov or call 1-888-ASK-USGS.

For an overview of USGS information products, including maps, imagery, and publications,

visit https://store.usgs.gov.

Any use of trade, firm, or product names is for descriptive purposes only and does not imply endorsement by the U.S. Government.

Although this information product, for the most part, is in the public domain, it also may contain copyrighted materials as noted in the text. Permission to reproduce copyrighted items must be secured from the copyright owner.

Suggested citation:

Wallick, J.R., Bach, L.B., Keith, M.K., Olson, M., Mangano, J.F., and Jones, K.L., 2018, Monitoring framework for evaluating hydrogeomorphic and vegetation responses to environmental flows in the Middle Fork Willamette, McKenzie, and Santiam River Basins, Oregon: U.S. Geological Survey Open-File Report 2018-1157, 66 p., https://doi.org/10.3133/ofr20181157.

ISSN 2331-1258 (online 


\section{Contents}

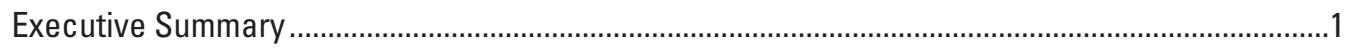

General Framework Monitoring Considerations .....................................................................1

High-Priority Approaches for Monitoring Hydrogeomorphic Responses to

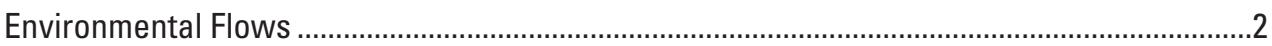

High-Priority Approaches for Monitoring Riparian Vegetation Responses to

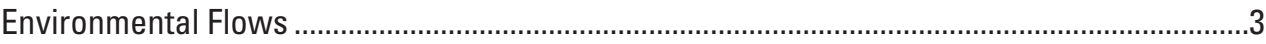

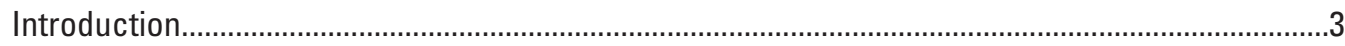

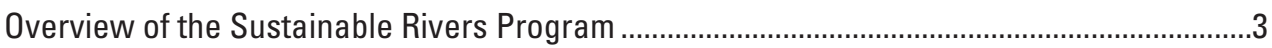

Study Definitions for Environmental Flow and Monitoring Terms ............................................

Implementation of the Sustainable Rivers Program in the Willamette River Basin ..................5

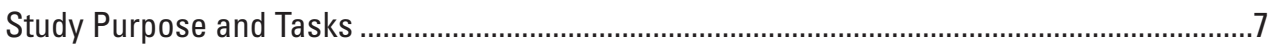

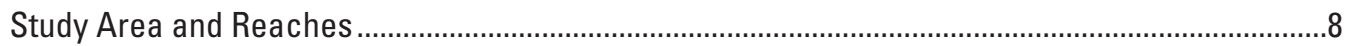

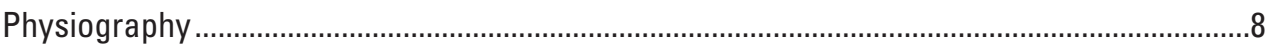

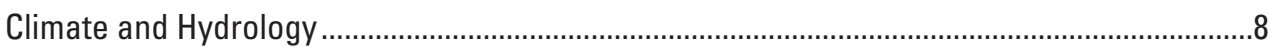

Geomorphology and Riparian Vegetation, Historical Alterations, and Implications for Environmental Flows .........................................................................................18

General Monitoring Framework Considerations ……................................................................

Spatial and Temporal Scales of Monitoring Activities ………..............................................19

Evaluating Streamflow Targets .....................................................................................20

Research to Refine Environmental Flow Recommendations .................................................23

Development of a Monitoring Plan and Leveraging Data Collection Across Multiple

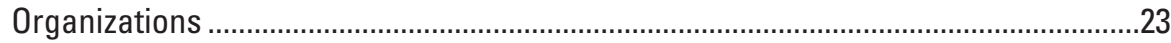

Monitoring Hydrogeomorphic Responses to Environmental Flows ................................................24

Approaches for Monitoring Water-Surface Elevations and Inundation ................................24

Approaches for Monitoring Channel Pattern, Planform, and Large Wood..............................29

Approaches for Monitoring Channel Bed Elevation ................................................................30

Approaches for Monitoring Bed-Material Texture …………....................................................31

Approaches for Monitoring Floodplain Landforms ............................................................33

Approaches for Monitoring Dewatering and Scour of Gravels in Spawning Reaches..........34

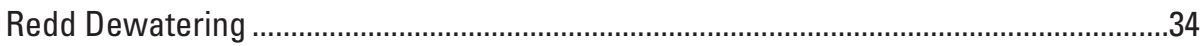

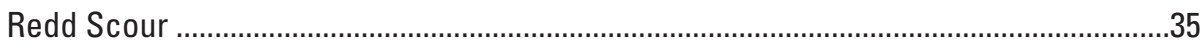

Monitoring Riparian Vegetation Responses to Environmental Flows .........................................36

Approaches for Monitoring Hydrogeomorphic Conditions that Influence Vegetation

Recruitment ......................................................................................................38

Approaches for Monitoring Stand Recruitment and Succession ..........................................40

Reach-Based Mapping to Track Vegetation Recruitment and Succession ....................40

Site-Scale Monitoring Tasks ......................................................................................40

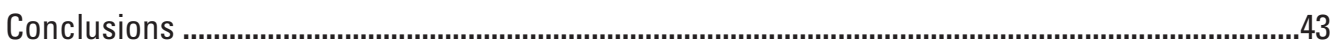

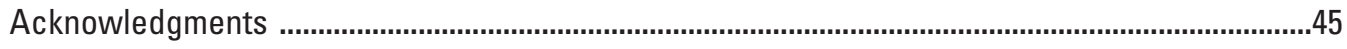

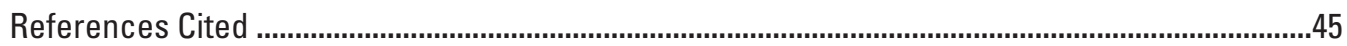




\section{Contents-Continued}

Appendix 1. Reach Characteristics and Monitoring Considerations ...............................................53

Appendix 2. Examples of Techniques for Evaluating and Documenting Flow Characteristics.......60

Appendix 3. Outstanding Research Questions and Additional Analyses to Support

Refinement of Sustainable Rivers Project Goals

Appendix 4. Examples of Existing Datasets and Monitoring Efforts that Complement the

Sustainable Rivers Project Monitoring Program

\section{Figures}

1. Graph showing environmental flow recommendations as described in Gregory and others (2007b) for the Middle Fork Willamette River, Oregon

2. Map showing study area for the monitoring framework in the Willamette River

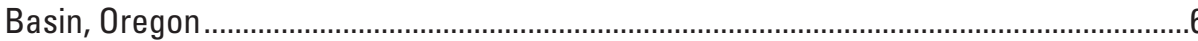

3. Map and images showing lower alluvial study reaches along the Middle Fork Willamette River, Oregon.

4. Map and images showing lower alluvial study reaches along the McKenzie River, Oregon

5. Map and images showing lower alluvial study reach along the North Santiam River, Oregon

6. Map and images showing lower alluvial study reaches along the South and main-stem Santiam Rivers, Oregon

7. Map showing spring Chinook salmon (Oncorhynchus tshawytscha) spawning reach on the Middle Fork Willamette River downstream of U.S. Army Corps of Engineers (USACE) dams, Oregon

8. Map showing spring Chinook salmon (Oncorhynchus tshawytscha) spawning reach on the South Fork McKenzie and McKenzie Rivers downstream of U.S. Army Corps of Engineers (USACE) dams, Oregon

9. Map showing spring Chinook salmon (Oncorhynchus tshawytscha) spawning reach on the North Santiam River downstream of U.S. Army Corps of Engineers (USACE) dams, Oregonl

10. Map showing spring Chinook salmon (Oncorhynchus tshawytscha) spawning reach on the South Santiam River downstream of U.S. Army Corps of Engineers (USACE) dams, Oregon

11. Map and transect example showing reach, zone, and site-scale monitoring activities and associated measurement frequencies for McKenzie River, Oregon ........21

12. Conceptual model of hydrogeomorphic responses to environmental flows and approaches for monitoring these responses in gravel-bed rivers downstream of U.S. Army Corps of Engineers dams in the Willamette River Basin, Oregon.

13. Conceptual model of vegetation recruitment, stand initiation, succession, and stand recycling, and approaches for monitoring those processes.

14. Monitoring approaches to evaluate black cottonwood establishment at Middle Fork Willamette, McKenzie, and Santiam River Basins, Oregon, summer 2015 (Jones and others, 2016). 


\section{Tables}

1. Summary of attributes for the lower, alluvial reaches within the study area in the Willamette River Basin Sustainable Rivers Program, Oregon.

2. Examples of environmental flow components, ecological goals, and approaches for evaluating whether streamflow targets are achieved....

3. Examples of environmental flow objectives for hydrogeomorphic processes and approaches for evaluating whether targets are achieved.

4. Examples of environmental flow objectives for black cottonwood (Populus trichocarpa) and approaches for evaluating whether targets are achieved.

5. Summary of key activities for monitoring hydrogeomorphic and vegetation responses to environmental flows in the Willamette River Basin, Oregon

\section{Conversion Factors}

Inch/Pound to International System of Units

\begin{tabular}{lcl}
\hline Multiply & By & To obtain \\
\hline acre & Area & square meter $\left(\mathrm{m}^{2}\right)$ \\
acre & 4,047 & hectare $(\mathrm{ha})$ \\
\hline & 0.4047 & \\
\hline cubic foot per second $\left(\mathrm{ft}^{3} / \mathrm{s}\right)$ & Flow rate & cubic meter per second $\left(\mathrm{m}^{3} / \mathrm{s}\right)$ \\
\hline
\end{tabular}

International System of Units to Inch/Pound

\begin{tabular}{lll}
\hline \multicolumn{1}{c}{ Multiply } & By & To obtain \\
\hline millimeter $(\mathrm{mm})$ & Length & \\
meter $(\mathrm{m})$ & 0.03937 & inch (in.) \\
kilometer $(\mathrm{km})$ & 3.281 & foot $(\mathrm{ft})$ \\
kilometer $(\mathrm{km})$ & 0.6214 & mile (mi) \\
meter $(\mathrm{m})$ & 0.5400 & mile, nautical $(\mathrm{nmi})$ \\
& 1.094 & yard $(\mathrm{yd})$ \\
\hline square meter $\left(\mathrm{m}^{2}\right)$ & Area & \\
square meter $\left(\mathrm{m}^{2}\right)$ & 0.0002471 & acre \\
square kilometer $\left(\mathrm{km}^{2}\right)$ & 10.76 & square foot $\left(\mathrm{ft}^{2}\right)$ \\
square kilometer $\left(\mathrm{km}^{2}\right)$ & 247.1 & acre \\
\hline & 0.3861 & square mile $\left(\mathrm{mi}^{2}\right)$ \\
\hline cubic meter per second $\left(\mathrm{m}^{3} / \mathrm{s}\right)$ & Flow rate & \\
\hline
\end{tabular}

\section{Datums}

Vertical coordinate information is referenced to the North American Vertical Datum of 1988 (NAVD 88).

Elevation, as used in this report, refers to distance above the vertical datum.

Horizontal coordinate information is referenced to the North American Datum of 1983 (NAD 83). 


\section{Abbreviations}

$\begin{array}{ll}\text { D50 } & \text { median diameter grain size } \\ \text { ESA } & \text { Endangered Species Act } \\ \text { FPKM } & \text { floodplain kilometer } \\ \text { GPS } & \text { Global Positioning System } \\ \text { ODFW } & \text { Oregon Department of Fish and Wildlife } \\ \text { RME } & \text { research monitoring and evaluation } \\ \text { RTK } & \text { real-time kinematic } \\ \text { SRP } & \text { Sustainable Rivers Program } \\ \text { TNC } & \text { The Nature Conservancy } \\ \text { USACE } & \text { U.S. Army Corps of Engineers } \\ \text { USGS } & \text { U.S. Geological Survey } \\ \text { VIP } & \text { Voluntary Incentive Program }\end{array}$




\title{
Monitoring Framework for Evaluating Hydrogeomorphic and Vegetation Responses to Environmental Flows in the Middle Fork Willamette, McKenzie, and Santiam River Basins, Oregon
}

\author{
By J. Rose Wallick', Leslie B. Bach², Mackenzie K. Keith', Melissa Olson³, Joseph F. Mangano', and \\ Krista L. Jones ${ }^{1}$
}

\section{Executive Summary}

This report summarizes a framework for monitoring hydrogeomorphic and vegetation responses to environmental flows in support of the Willamette Sustainable Rivers Program (SRP). The SRP is a partnership between The Nature Conservancy (TNC) and U.S. Army Corps of Engineers (USACE) to provide ecologically sustainable flows downstream of dams while still meeting human needs and congressionally authorized purposes. TNC, USACE, and U.S. Geological Survey (USGS) developed this framework specifically for the spawning reaches and lower, alluvial parts of the Middle Fork Willamette, McKenzie, North Santiam, South Santiam, and main-stem Santiam Rivers. The report has three primary elements summarized in the three subsections that follow.

\section{General Framework Monitoring Considerations}

- Although streamflow is a key influence on aquatic and riparian habitats along rivers in the study area, many other factors such as channel morphology, river channel slope, sediment supply, and stream temperature also determine habitat availability. The monitoring approaches outlined here are useful for evaluating relations between streamflow and physical habitat characteristics and also can be used to assess the relative importance of streamflow amid other factors affecting physical habitat.

- To create a broadly applicable monitoring framework for the SRP as well as other environmental flow programs, the term "environmental flow recommendations" is used to broadly describe recommended streamflow targets and their associated ecological objectives.

- The monitoring approaches for each river corridor are similar across the study area. However, some consideration of the unique conditions along each reach will be needed when establishing basinwide priorities for future monitoring activities and developing reach-specific monitoring plans. Baseline datasets describing water levels, inundation patterns, channel features, and vegetation conditions generated from initial phases of a future monitoring program could inform the development of more refined monitoring recommendations, tailored to each reach, for subsequent monitoring phases.

- Data collection will be needed at varying spatial and temporal scales, depending on the channel type, anticipated environmental flow response, and indicator being monitored. Monitoring activities in this framework are described for three distinct spatial scales - reaches, zones, and sites. Monitoring at the reach-scale (spanning 10-30 kilometers [km]) is useful for assessing longitudinal trends at infrequent (5-10 years) timeframes. Monitoring zones target shorter $(0.5-2 \mathrm{~km})$ reaches of the floodplain where reach-scale techniques can be applied for more frequent mapping and measurements (1-3 years). Site-scale observations can be conducted on a more frequent basis (monthly or as needed). Sites are situated within reaches and monitoring zones and are ideally co-located along floodplain transects to better support linkages between hydrogeomorphic and vegetation conditions.

\footnotetext{
${ }^{1}$ U.S. Geological Survey.

${ }^{2}$ The Northwest Power and Conservation Council.

${ }^{3}$ The Nature Conservancy.
} 
- Streamgages in or near each reach (appendix 1) can be used to determine which environmental flow targets were achieved. To permit comparisons between environmental flow recommendations, actual streamflows, and the hydrogeomorphic and vegetation responses to these flows, methods will need to be developed for consistently defining the hydrograph characteristics of each environmental flow recommendation.

- Baseline data describing channel features, water levels, inundation patterns, and vegetation conditions across the study area are currently lacking, thereby making it difficult for SRP stakeholders to set realistic hydrogeomorphic and vegetation objectives for each SRP environmental flow component and to measure progress towards those objectives. However, the monitoring activities described in this report could yield baseline datasets to inform SRP environmental flow components and targets. Over time, these approaches could provide a robust basis for adaptively assessing and refining SRP flow targets.

- Implementation of the monitoring program would benefit from the development of a monitoring plan describing the specific monitoring activities that will be conducted, and the locations, timing, and conditions for these activities. The plan also could specify the protocols for each monitoring approach and the quality assurance and quality control processes that will ensure high-quality data, and could provide for data reporting and synthesis.

\section{High-Priority Approaches for Monitoring Hydrogeomorphic Responses to Environmental Flows}

Flow recommendations focus on meeting certain hydraulic targets (generally defined through water-surface elevation and inundation extent) to provide critical habitats for native species at different times of the year. Additionally, flow recommendations are related to maintaining geomorphic processes that create and sustain important riparian and aquatic habitats. Because water-surface elevation and inundation extent are dictated by channel and floodplain morphology, which is controlled by geomorphic processes, we group monitoring activities for hydraulic and geomorphic processes because they are inherently related to each other (hence, our usage of the term, "hydrogeomorphic processes"). These coupled response variables can be evaluated by the following approaches:

- Collecting baseline datasets to characterize watersurface elevations and inundation patterns for different stream discharges, identifying when these inundation levels are achieved and the duration of these flow events. Once relations between discharge and inundation extent are established, continuous discharge records can be applied to determine the frequency and duration of discharge events that attain specified inundation levels.

- Collecting baseline information describing channel morphology and spatial distribution of channel features along each reach and comparing this information with data from subsequent time periods to link changes in channel planform with hydrograph characteristics. This assessment could identify gains and losses in features that provide important habitats and evaluate the role of streamflow magnitude, duration, and frequency in determining patterns of channel change. Repeat mapping from aerial photographs or lidar can be efficiently carried out after large floods; otherwise, every $2-3$ years.

- Measuring changes in channel bed elevation to document patterns of incision or aggradation that can influence the availability of important habitats (for example, gains and losses in pools or riffles) and identify areas where changes in channel depth may influence local inundation patterns. Changes in bed elevations could be measured with repeat surveys every 10 years or following large-magnitude flood events at the reach-scale and more frequently in areas with suspected incision or aggradation. Mapped distributions of bed elevations also can be coupled with measured water-surface elevations to determine variation in water depths for different flows and to evaluate changes in aquatic habitats for different streamflows.

- Characterizing changes in bed texture (such as fining or coarsening) with repeat measurements of bed-material sediment at floodplain transects every 10 years or following a large-magnitude flow event. Spatial and temporal variation in bed-material grain size has implications for aquatic habitats and geomorphic processes. For example, bed coarsening may decrease the availability of suitable spawning habitats for spring Chinook salmon (Oncorhynchus tshawytscha) and also can cause the channel bed to be more stable during future high-flow events.

- Evaluating deposition and scour along floodplain landforms at the reach scale with repeat lidar surveys every 10 years or at site scale with repeat groundbased surveys every 1-3 years (ideally at floodplain transects). Deposition of floodplain channels can reduce inundation extent (potentially reducing highflow habitats), whereas overbank scour may create or enhance high-flow channels. 


\section{High-Priority Approaches for Monitoring Riparian Vegetation Responses to Environmental Flows}

Environmental flow recommendations also were developed to promote various stages of floodplain forest succession to create and maintain a diverse mosaic of floodplain forest habitats. The flow targets for vegetation and associated monitoring approaches focus on black cottonwood (Populus trichocarpa) because its life history is tightly coupled with floodplain hydrology and disturbance processes. Monitoring approaches for black cottonwood restoration include:

- Identifying potential recruitment sites for black cottonwood by mapping unvegetated gravel bars from aerial photographs or lidar. Bare gravel bars are readily mapped from lidar or aerial photographs, and channel segments that are more laterally active likely would have a greater area of unvegetated gravel bars than straighter or single-thread segments along revetments or resistant geologies that limit migration.

- Monitoring stand recruitment and early succession at the reach scale by mapping seral stages (intermediate stages of ecological succession) of floodplain vegetation from aerial photographs and lidar every 10 years. Repeat mapping would provide quantitative measurements of floodplain forest canopy growth and succession. Additionally, these monitoring approaches could identify areas of stand recruitment or floodplain recycling.

- Monitoring black cottonwood recruitment in plots at the site scale during spring recession and summer base flows. Small areas along transects could be identified as suitable for seedling establishment within each reach. Initial focus could be along transects within laterally dynamic monitoring zones. If resources allow, additional monitoring could be completed along transects in stable monitoring zones.

- Monitoring stages of succession, including stem exclusion and early seral succession along transects of different ages. Reach-scale landcover mapping from aerial photographs at decadal scales would complement site-scale observations and aid in characterizing overall status and condition of floodplain forests, and could be related to streamflows and hydrogeomorphic processes.

\section{Introduction}

This study is a collaborative effort of The Nature Conservancy (TNC), U.S. Army Corps of Engineers (USACE), and U.S. Geological Survey (USGS) to develop a monitoring framework to inform adaptive management of environmental flows downstream of USACE dams on the Middle Fork Willamette, McKenzie, South Santiam, North Santiam, and main-stem Santiam Rivers.

\section{Overview of the Sustainable Rivers Program}

TNC and the USACE formed the national Sustainable Rivers Project (SRP) in 2002 to develop, implement, and refine ecologically sustainable flows downstream of dams while meeting human needs and congressionally authorized purposes (Warner and others, 2014). Environmental flow recommendations are developed based on estimated and observed pre- and post-dam streamflow and the hydrogeomorphic and vegetation conditions that support key aquatic and riparian communities through an iterative process that incorporates input from experts (for example, Gregory and others, 2007a; 2007b). These recommendations are developed for specific river segments and are composed of multiple, seasonally varying environmental flow components. Each environmental flow component has distinct ecological goals and streamflow targets for achieving those goals (see section, "Study Definitions for Environmental Flow and Monitoring Terms" for detailed explanation of flow recommendations, ecological goals, and targets). An example of environmental flow recommendations for the Middle Fork Willamette River is provided in figure 1 (Gregory and others, 2007b).

Flow recommendations are then evaluated by dam operators for feasibility, implemented where possible, and monitored to evaluate their effects on the river ecosystem and dam operations (Tharme, 2003; Acreman and Dunbar, 2004; Richter and others, 2006; The Nature Conservancy, 2017). Because initial flow recommendations often are made using the best available knowledge of streamflow and ecological relations, adaptive management and monitoring programs are necessary to determine the success of implemented flows in meeting ecosystem objectives and to refine the goals of the environmental flow recommendations over time (Higgins and others, 2011). 


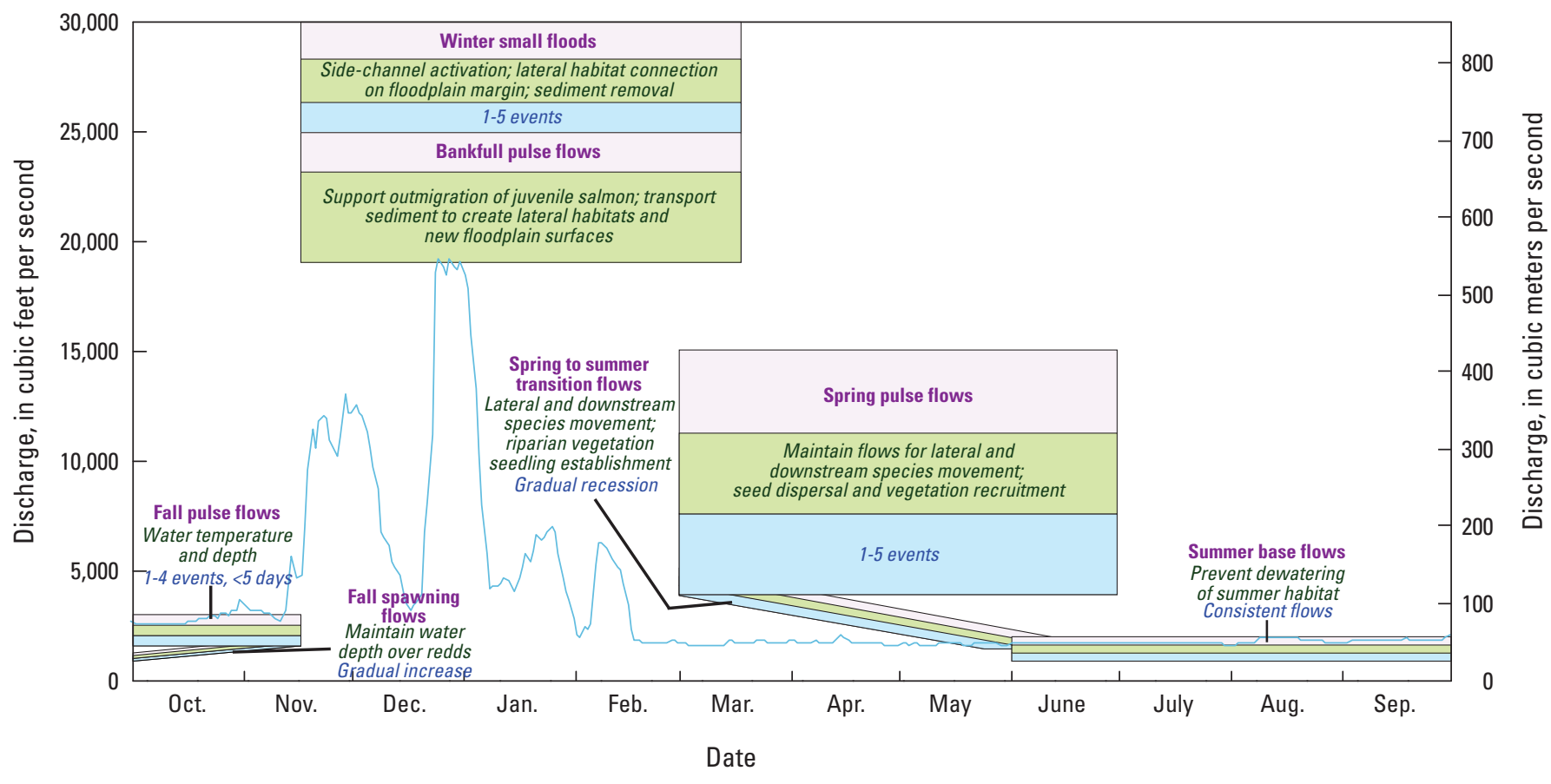

EXPLANATION

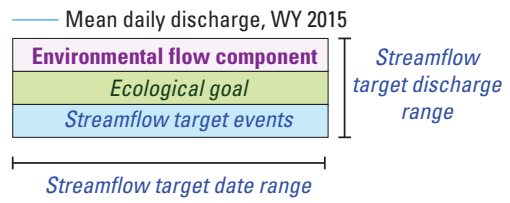

Figure 1. Environmental flow recommendations as described in Gregory and others (2007b) for the Middle Fork Willamette River, Oregon. Ecological goals, environmental flow components, and streamflow targets are compared with daily mean flow at U.S. Geological Survey streamgage 14152000 (Middle Fork Willamette River at Jasper, Oregon).

\section{Study Definitions for Environmental Flow and Monitoring Terms}

This report uses streamlined environmental flow and monitoring terminology that draws upon language specific to the SRP while attempting to create a framework that is broadly applicable to other flow management and river monitoring programs. Key terms used in this report are defined as follows:

- Flow recommendations-SRP environmental flow recommendations have been developed by stakeholders for the Middle Fork Willamette, McKenzie and Santiam River Basins (Gregory and others, 2007b; Risley, Bach, and Wallick, 2010; and Bach and others, 2013). For this report, the term "flow recommendations" refers to the suite of environmental flow components that were prescribed for a particular reach or river basin within the Willamette SRP study area.
- Environmental flow component-Specific component of the flow recommendation that is linked with a major element of the annual hydrograph and associated with specific ecological goals and streamflow targets. Examples include "Spring pulse flows" and "Summer base flows" (table 2).

- Ecological goals-Desired ecological outcomes associated with each environmental flow component. Ecological goals are developed by SRP stakeholders and are hypothesized to result from implementation of environmental flow recommendations (Konrad, 2010). This report references select ecological goals as summarized from the environmental flow workshops for the study area (Gregory and others, 2007b; Risley Bach, and Wallick, 2010; and Bach and others, 2013).

- Streamflow target - Specific streamflows associated with each environmental flow component for achieving the ecological goals. Streamflow targets are 
defined by SRP stakeholders in terms of hydrograph characteristics (for example, discharge magnitude, frequency, and duration of flow events within specified period).

- Hydrogeomorphic objectives-Narrowly defined sub-goals describing hydrogeomorphic aspects of ecological goals (for example, changes in inundation, flow depth, and channel morphology that will benefit aquatic and riparian habitat). Hydrogeomorphic objectives in this report are examples developed to show how the ecological goals could be refined to create robust, measurable objectives that could be readily evaluated through a future monitoring program (adapted from Pacific Northwest Aquatic Monitoring Partnership [PNAMP], 2017).

- Vegetation objectives - Narrowly defined sub-goals describing vegetation aspects of ecological goals. Vegetation objectives in this report focus on black cottonwood (Populus trichocarpa) and are examples developed to show how ecological goals could be refined to create robust, measurable objectives that could be readily evaluated through a future monitoring program (adapted from PNAMP, 2017).

- Monitoring indicator-Anticipated response (or lack of response) used to signal the types and levels of change in hydrogeomorphic or vegetation conditions that occurs from implementation of various flow components. In this report, an indicator informs the status of the associated hydrogeomorphic or vegetation objective and broader ecological goal. Indicators could be estimated through one or more metrics analyzed over a specified spatial or temporal extent (definition modified from PNAMP, 2017).

- Monitoring metric - A specific value, with a defined unit of measure (quantitative or qualitative), obtained through direct measurement at a defined spatial and temporal scale. One or more metrics can be used to estimate indicators (definition modified from PNAMP, 2017).

To illustrate linkages between environmental flow recommendations, environmental flow components, hydrogeomorphic and vegetation objectives, monitoring indicators and metrics, consider the environmental flow recommendation for winter bankfull pulse flows on the Middle Fork Willamette River, which draws upon Gregory and others, (2007b; fig. 1), and current understanding of hydrogeomorphic and vegetation conditions for this reach (summarized in appendix 1):

- Environmental flow component-Winter bankfull pulse flows.
- Ecological goal-Support downstream migration of juvenile salmon and create new floodplain surfaces, transporting gravel and creating lateral habitats.

- Streamflow target - Discharge at USGS streamgage at Jasper is $19,000-25,000 \mathrm{ft}^{3} / \mathrm{s}$, for $1-5$ flow events during November 15-March 15.

- Hydrogeomorphic objective - Increase gravel bars, which are indicative of gravel transport and provide rearing habitat for spring Chinook salmon (Oncorhynchus tshawytscha) in the late spring and early summer (Schroeder and others, 2007).

- Vegetation objective-Create new surfaces for cottonwood establishment by scouring vegetation from existing gravel bars and depositing new sediment in areas that will provide suitable colonization conditions.

- Monitoring indicators -Abundance of unvegetated areas on gravel bars (hydrogeomorphic indicator) and abundance of established shrub and floodplain forest (vegetation indicator).

- Monitoring metrics - Area of unvegetated gravel bars (hydrogeomorphic metric) and area of established vegetation (shrub or forest) on low-elevation bars and floodplains.

- Monitoring approach - The monitoring approach could entail repeat mapping of aerial photographs collected in summer low-flow months.

\section{Implementation of the Sustainable Rivers Program in the Willamette River Basin}

The Willamette River Basin in Oregon is one of eight demonstration sites in the SRP (Warner and others, 2014). The Willamette River and its tributaries support a rich diversity of aquatic flora and fauna, including important runs of salmon and steelhead. The river also is home to most of Oregon's population, and provides vital goods and services to the region and beyond. The USACE operates 13 dams in the Willamette River Basin, including 11 multiple-purpose storage reservoirs and 2 reregulating reservoirs that are all located on major tributaries to the Willamette River (fig. 2; U.S. Army Corps of Engineers, 2007). The SRP is focused on stream segments downstream of 10 USACE dams, which support important spawning and rearing areas for Endangered Species Act (ESA)-listed spring Chinook salmon including the Middle Fork Willamette, McKenzie, and Santiam Rivers (fig. 2). The USACE operates the system of dams primarily for flood damage reduction, as well as hydropower, recreation, water supply, and flow augmentation for fish and wildlife. 


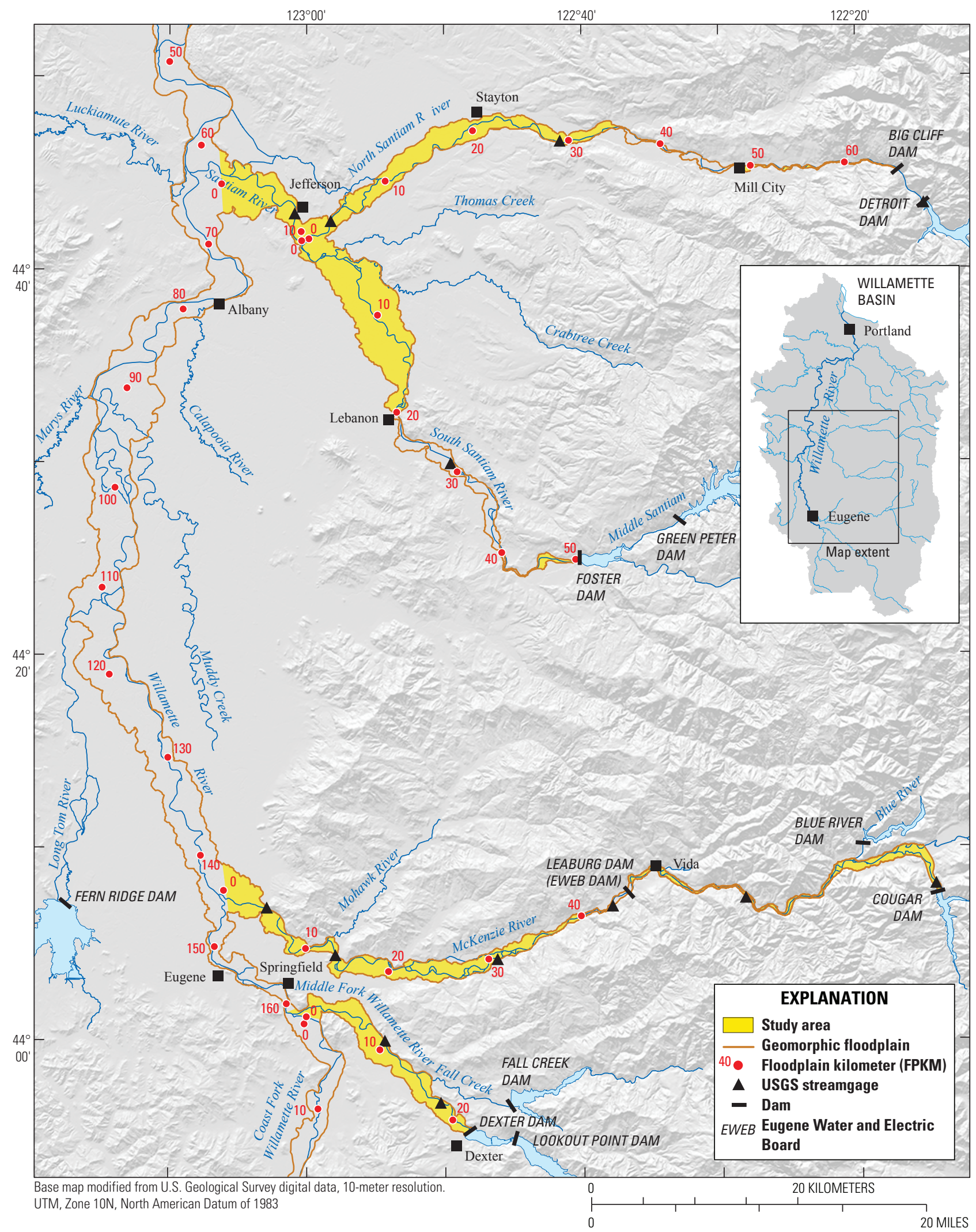

Figure 2. Study area for the monitoring framework in the Willamette River Basin, Oregon. 
Dam operations have changed the volume and timing of water flow in these regulated rivers, resulting in decreased peak and spring flows, increased low flows, and infrequent bankfull flows. Alterations to the natural flow regime affect the health and viability of the freshwater ecosystems and associated aquatic and terrestrial species. To address these issues, TNC and USACE have used the SRP to determine environmental flow requirements downstream of the dams and to identify opportunities to restore aspects of the flow regime. The program objectives Konrad (2010, p. 7) describes for the Middle Fork Willamette River SRP are broadly applicable to the entire Willamette SRP:

The ecological goals include re-establishment of physical processes creating and connecting in-channel and off-channel habitats, recruitment of cottonwood on floodplains, promoting salmon migration, and mitigating thermal impacts of the dam releases.

Environmental flow frameworks and flow recommendations were determined separately for the Coast Fork Willamette, Middle Fork Willamette, McKenzie, and Santiam River Basins, and then combined and evaluated for basin-wide implementation. Gregory and others (2007a) summarized streamflow and ecological relations for key Willamette species in the upper Willamette River Basin and provided detailed hydrologic information for the Middle and Coast Forks of the Willamette River. Subsequent reports compiled background information on hydrology, geomorphology, riparian vegetation, and biota for the McKenzie and Santiam Rivers (Risley, Bach, and Wallick, 2010; Risley and others, 2012). A series of expert workshops resulted in environmental flow recommendations for the Middle Fork Willamette (Gregory and others, 2007b); McKenzie (Risley, Bach, and Wallick, 2010); and the North, South, and main-stem Santiam Rivers (Bach and others, 2012). The flow recommendations for each river are divided into environmental flow components-specifically, fall spawning flows, fall pulse flows, winter high flows, winter small floods, spring pulse flows, spring to summer transition flows, and summer base flows based on ecological goals. By design, the flow recommendations are based on environmental needs, and, therefore, include flow conditions that cannot currently be implemented because of the authorized purpose of flood control and other congressional authorizations (such as the recommendation for large winter floods on Middle Fork Willamette River; Gregory and others, 2007b).

Initial implementation has focused on the Middle Fork Willamette River downstream of 4 of the 13 USACE dams. A subset of the environmental flow components has been implemented in all years following the completion of the Middle Fork Willamette River flow recommendations in 2008 (Konrad, 2010; Konrad and others, 2011; Warner and others, 2014; Jones and others, 2016). SRP flow recommendations also have been achieved in the McKenzie River Basin (Jones and others, 2016) and Santiam River Basin, although implementation in the Santiam River Basin has not yet been comprehensively documented. Monitoring by Jones and others (2016) documented vegetation and geomorphic responses to environmental flows on the Middle Fork Willamette and McKenzie Rivers.

\section{Study Purpose and Tasks}

The purpose of this study is to develop a monitoring framework for evaluating hydrogeomorphic and vegetation responses to environmental flows. In the future, this monitoring framework could support ongoing adaptive management of the SRP environmental flow program in the Willamette River Basin. It also may provide a platform for evaluating responses to restoration activities and other management practices.

This framework consists of monitoring indicators and metrics for evaluating the hydrogeomorphic and vegetation responses to environmental flows and the associated monitoring approaches for quantifying these monitoring indicators and metrics (see full definitions in section, "Study Definitions for Environmental Flow and Monitoring Terms"). To permit quantitative linkages between flow recommendations, ecological goals, and monitoring indicators, hydrogeomorphic and vegetation objectives are developed to provide examples of narrowly framed, measurable sub-goals that directly relate to ecological goals and can be readily evaluated using the approaches described in this report.

The objectives, monitoring indicators, and metrics described in this report focus on two sets of processes directly influenced by environmental flows: (1) hydrogeomorphic and (2) riparian vegetation processes. Because water-surface elevation and inundation extent are dictated by channel and floodplain morphology, which is controlled by geomorphic processes, we group monitoring activities for hydraulic and geomorphic processes because they are inherently related to each other (hence, our use of the term, "hydrogeomorphic processes"; Sidle and Onda, 2004).

Specific tasks in developing the monitoring framework summarized in this report include the following:

1. Delineation of study reaches and zones downstream of USACE dams for detailed monitoring in the Middle Fork Willamette, McKenzie, and Santiam River Basins that are aligned with established SRP flow targets.

2. Synthesis of existing information on hydrology, channel morphology, riparian vegetation, environmental flow recommendations, and anticipated hydrogeomorphic and vegetation responses for each study reach. This information provides a basis for developing monitoring indicators and approaches, and for developing examples of measurable, narrowly defined hydrogeomorphic and vegetation objectives that could be directly compared with monitoring results and used to evaluate progress towards ecological goals. 
3. Identification of a set of monitoring indicators and metrics that can be used to assess hydrogeomorphic and vegetation responses to environmental flows that are tailored and adapted to the unique conditions of each study reach.

4. Summary of the monitoring approaches for assessing the indicators (including location, spatial extent, timing and frequency of measurements), thereby providing a basis for developing more specific monitoring plans along each study reach.

\section{Study Area and Reaches}

The primary study area for this monitoring framework is the lower, alluvial reaches of the Middle Fork Willamette, McKenzie, South Santiam, North Santiam, and main-stem Santiam Rivers (figs. 2-6; table 1). A secondary focal area for the monitoring report is the spawning reaches immediately downstream of USACE dams (figs.7-10). Although the SRP encompasses a much broader area, extending from USACE dams to the mouth of each sub-basin (fig. 2), habitats within the spawning and lower alluvial reaches are most likely to be directly influenced by dam operations and, therefore, are the focus of the monitoring activities described in this report. The spawning locations for spring Chinook salmon are in confined canyon reaches where the water temperatures and the spatial extent, duration and depth of inundation directly affect redd (spawning nests formed in channel substrate) survival. In contrast, alluvial reaches are situated farther downstream in unconstrained valley segments where the hydrogeomorphic and vegetation processes are more sensitive to environmental flow releases than those along upstream canyon reaches. To provide context for the monitoring framework, this section provides brief descriptions of physiography, climate, and hydrology of the study area and summarizes historical alterations and present-day geomorphology and riparian vegetation of the lower alluvial reaches. More detailed descriptions of channel and vegetation conditions and pragmatic goals, objectives, and monitoring approaches for each of the alluvial reaches are provided in appendix 1.

\section{Physiography}

The Willamette Valley is a broad, alluvial plain flanked by two deeply dissected mountain ranges. The Willamette River flows through this valley, draining $28,000 \mathrm{~km}^{2}$ of northwestern Oregon before joining the Columbia River near Portland, Oregon. The Coast Range forms the western boundary of the watershed, and the taller Cascade Range forms the eastern boundary and contributes most of the flow and sediment to the Willamette River. The Willamette River and its major tributaries have been incising through Pleistocene sediments that compose the main floor of the Willamette Valley for about the last 10,000 years (O'Connor and others, 2001). As a result, the Holocene floodplains of these rivers are inset within topographically higher Pleistocene terraces and correspond with the extent of historical flooding and fluvial processes. Major tributaries to the Willamette River originate in the Cascade Range and include the Middle Fork Willamette $\left(3,530 \mathrm{~km}^{2}\right)$, McKenzie $\left(3,450 \mathrm{~km}^{2}\right)$, and Santiam $\left(4,550 \mathrm{~km}^{2}\right)$ River Basins (fig. 2).

\section{Climate and Hydrology}

The Willamette Valley has a Mediterranean climate with cool, wet winters and warm, dry summers. The valley floor receives 1,000 millimeters per year $(\mathrm{mm} / \mathrm{yr})$ of precipitation, primarily as rainfall during the winter. Headwater reaches that originate along the crest of the Cascade Range receive as much as $2,600 \mathrm{~mm} / \mathrm{yr}$ of precipitation, which falls as rain and snow primarily in the winter (Oregon State University, 2013). Historically, peak flows generally occurred in winter, with major floods typically resulting from basin-wide rain-onsnow events (Harr, 1981). Although precipitation is greatest along the crest of the Cascade Range, rainfall and snowmelt infiltrate through the young, porous volcanic rocks of the High Cascades geologic province, supporting steady year-round discharge at large spring complexes in this region (Stearns, 1928; Tague and Grant, 2004; Jefferson and others, 2006). In contrast, the older, less-permeable Western Cascades are steep and highly dissected, causing stream discharge to be much more responsive to storm runoff than in the High Cascades.

Streamflows are measured throughout the Willamette River Basin at USGS streamgages, including the more than 10 active streamgages in major rivers of the study area (fig. 2; appendix 1). Streamflows in this the study area are regulated by 10 of the 13 USACE dams in the Willamette Valley Project. Streamflows in the study area also are influenced by several smaller dams and projects, such as municipal and irrigation withdrawals from the North and South Santiam Rivers and McKenzie River (appendix 1; Risley, Bach, and Wallick, 2010; Risley and others, 2012). Regulated and unregulated flow data have been computed and analyzed for each of the main tributary basins to determine changes in hydrologic statistics and environmental flow components and help with the development of environmental flow recommendations (Gregory and others, 2007a; Risley, Wallick and others, 2010; Risley and others, 2012). 
ப் $\dot{0} \quad \dot{0} \overline{0}$

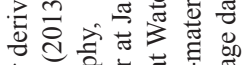

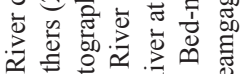

물

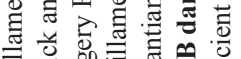

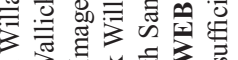

ᄃ்

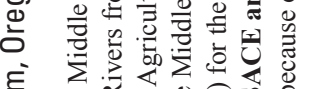

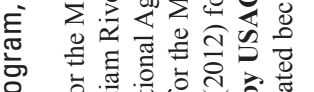

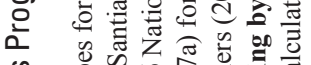

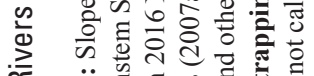

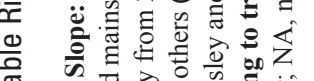

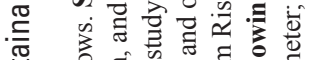

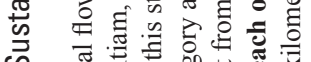

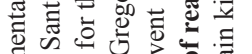

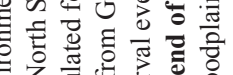

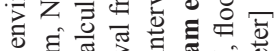

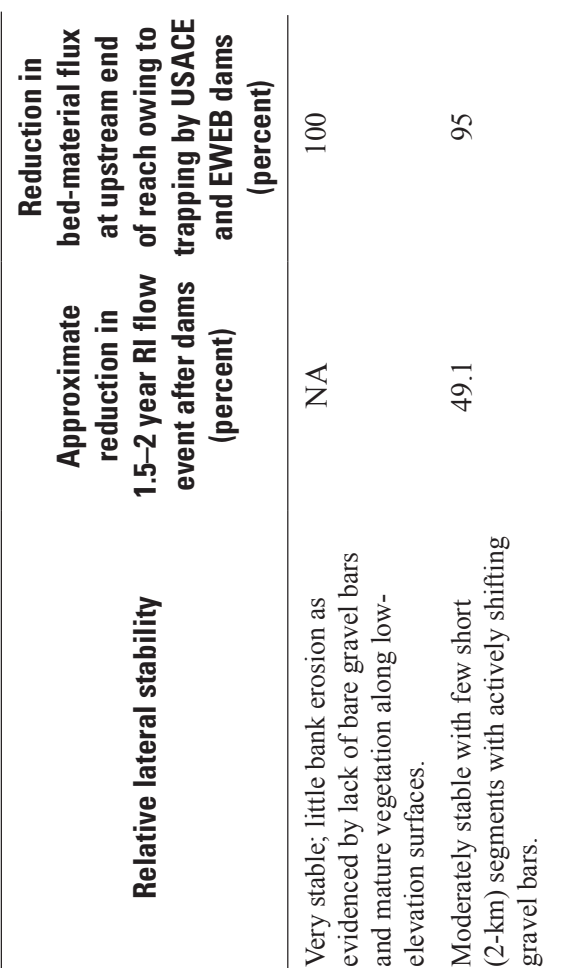

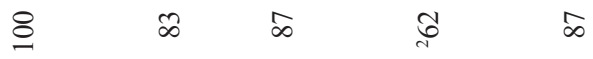

क

톤

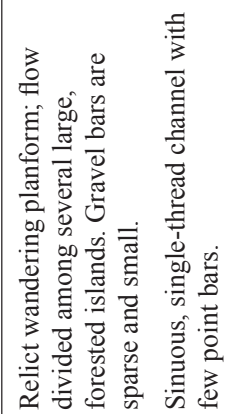

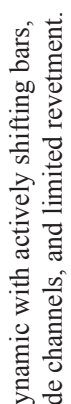

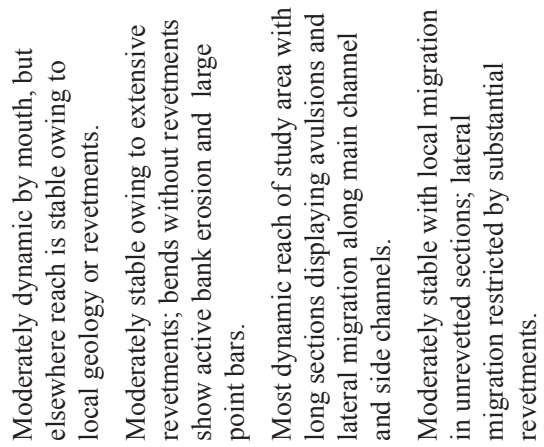

$\begin{array}{llll}\mathbb{Z} & \infty & 0 & 0 \\ \text { i } & \infty & \text { nे }\end{array}$

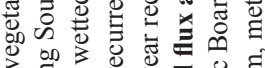

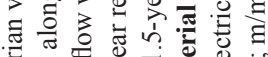

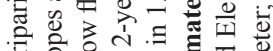

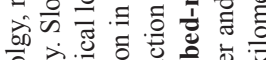

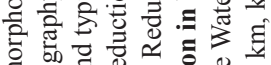

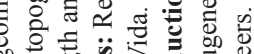

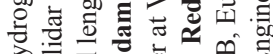

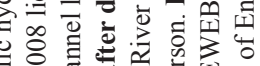

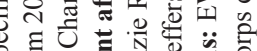

की

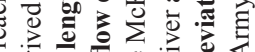

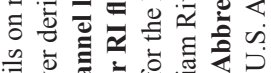

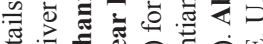

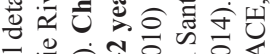

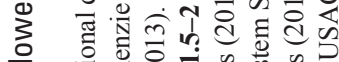

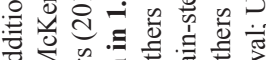

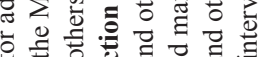

×

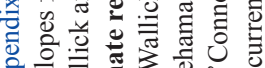

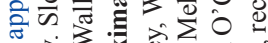

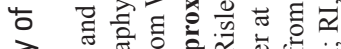

㐫

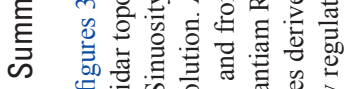

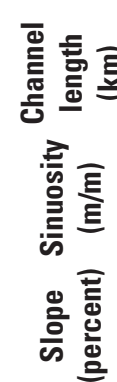

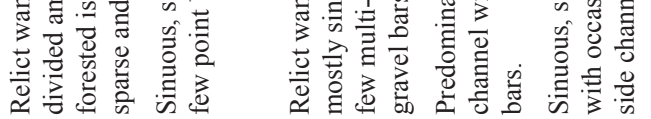

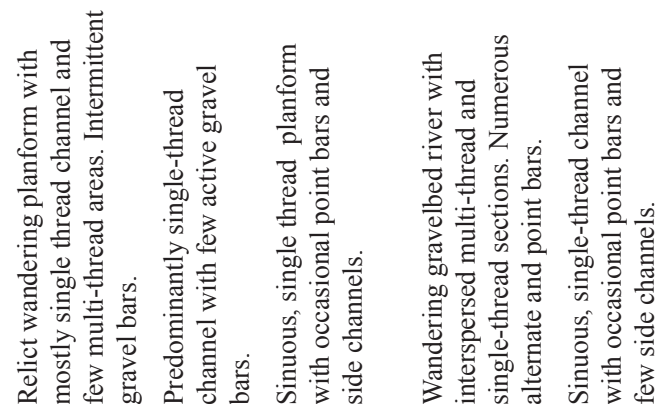

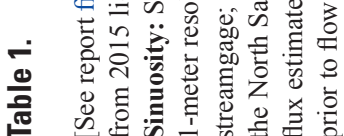

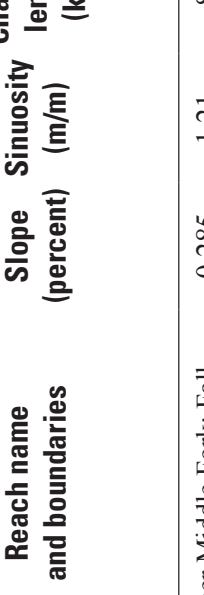




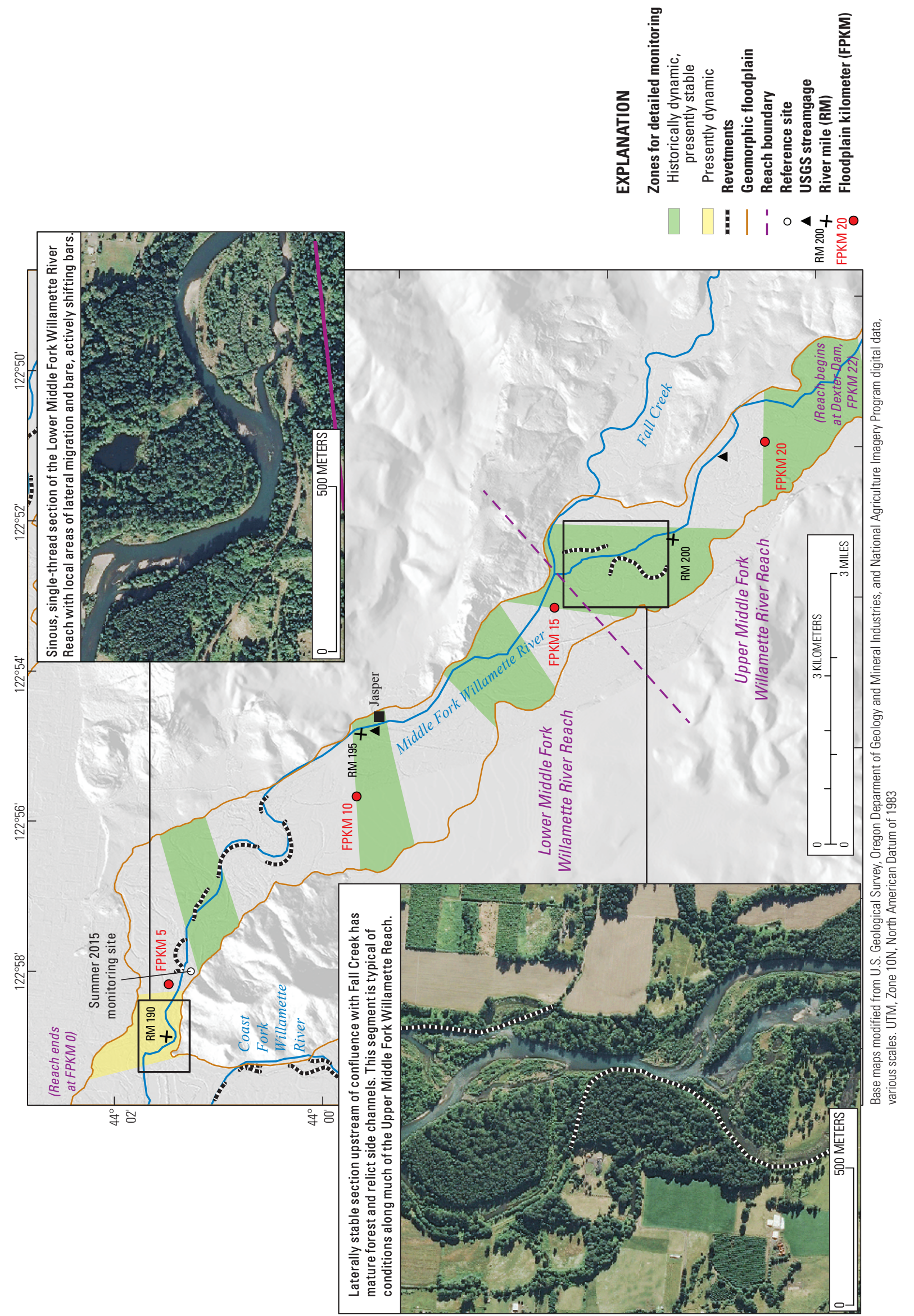

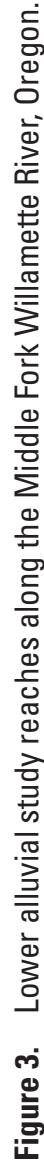



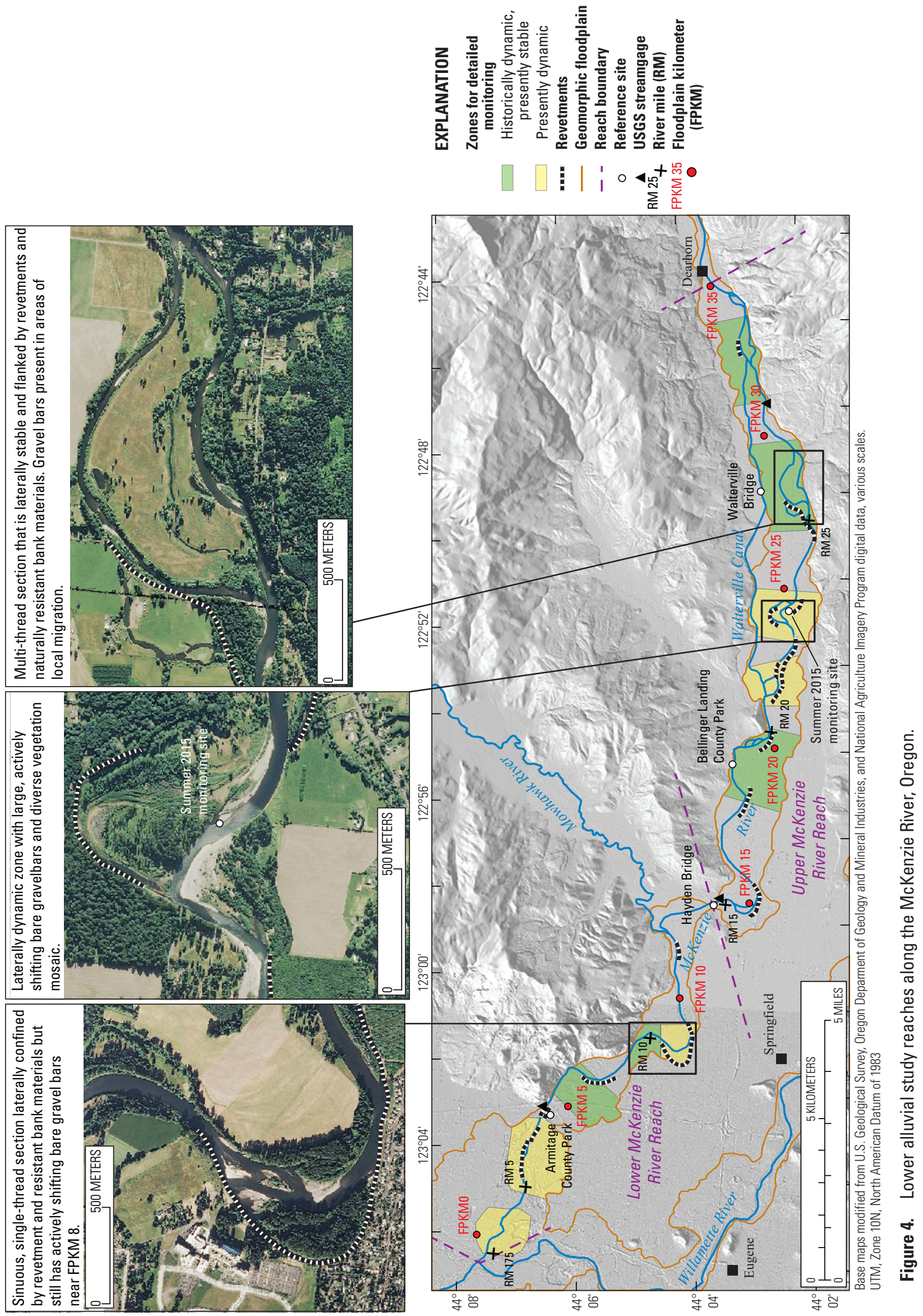

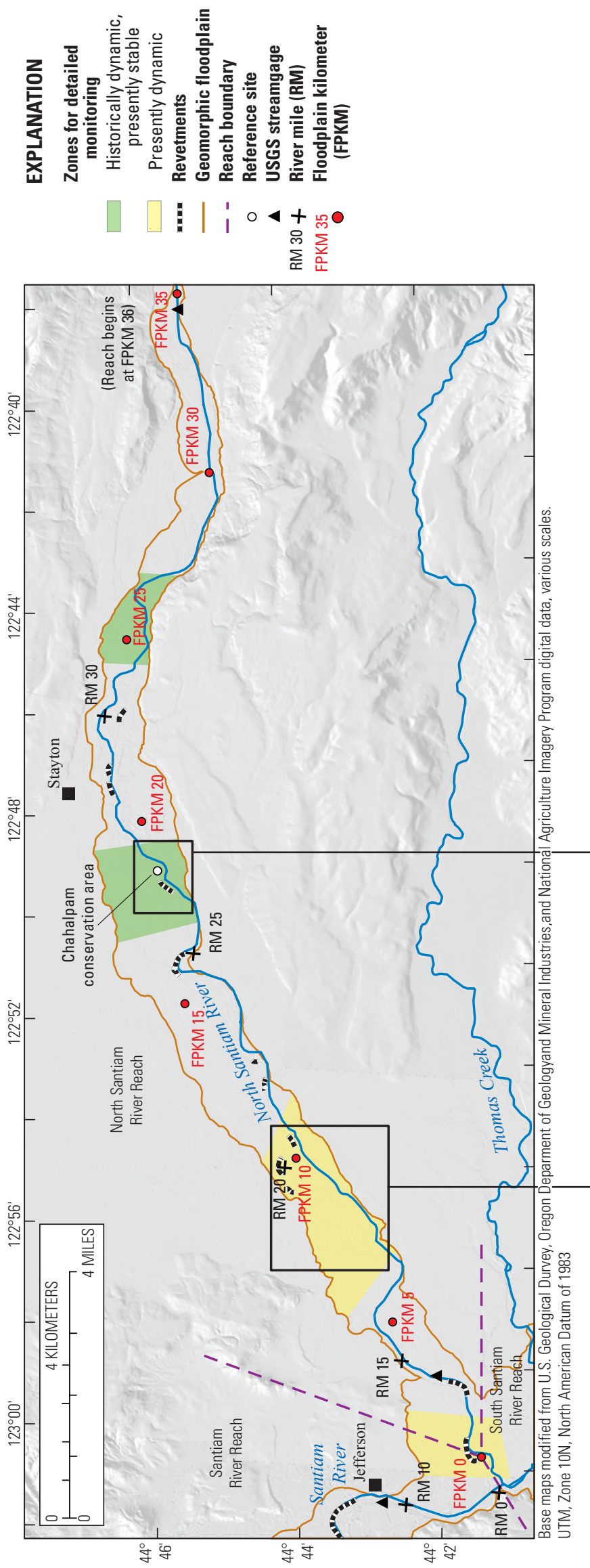

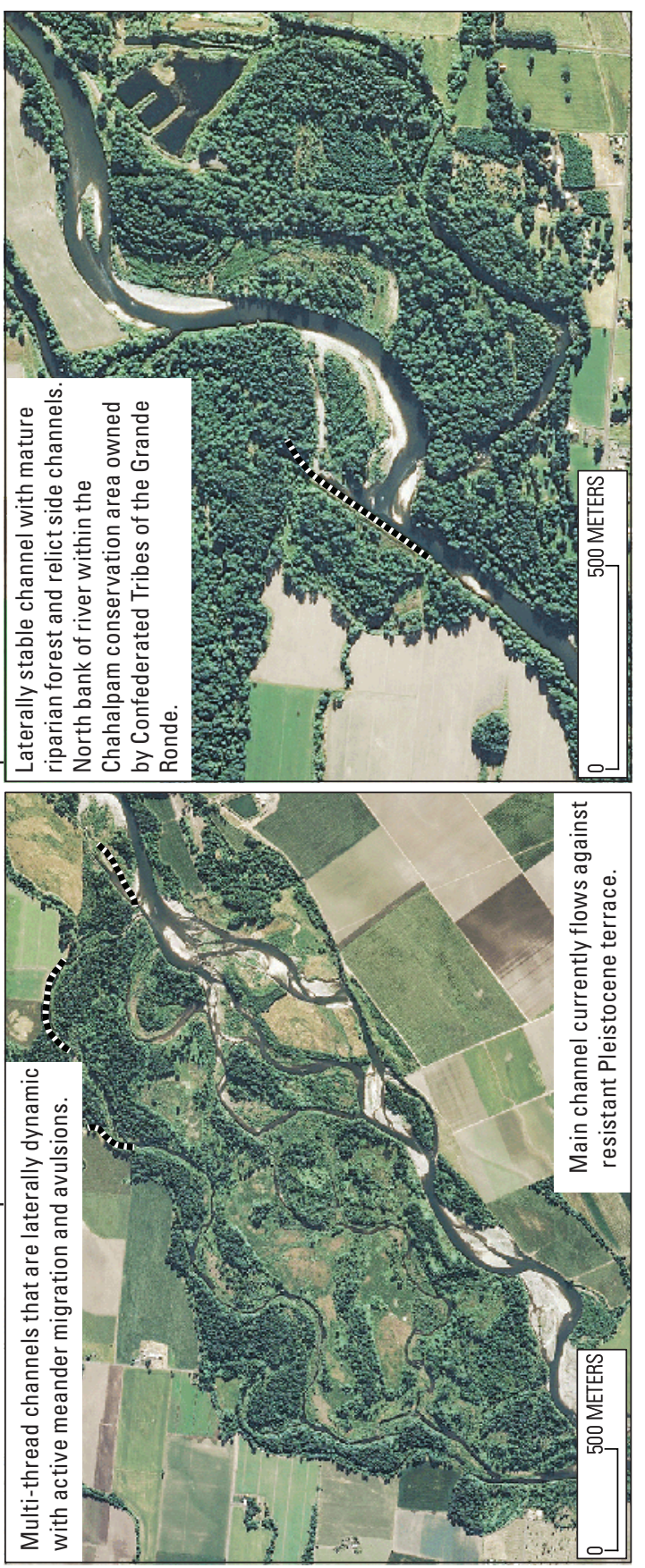

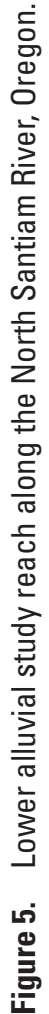




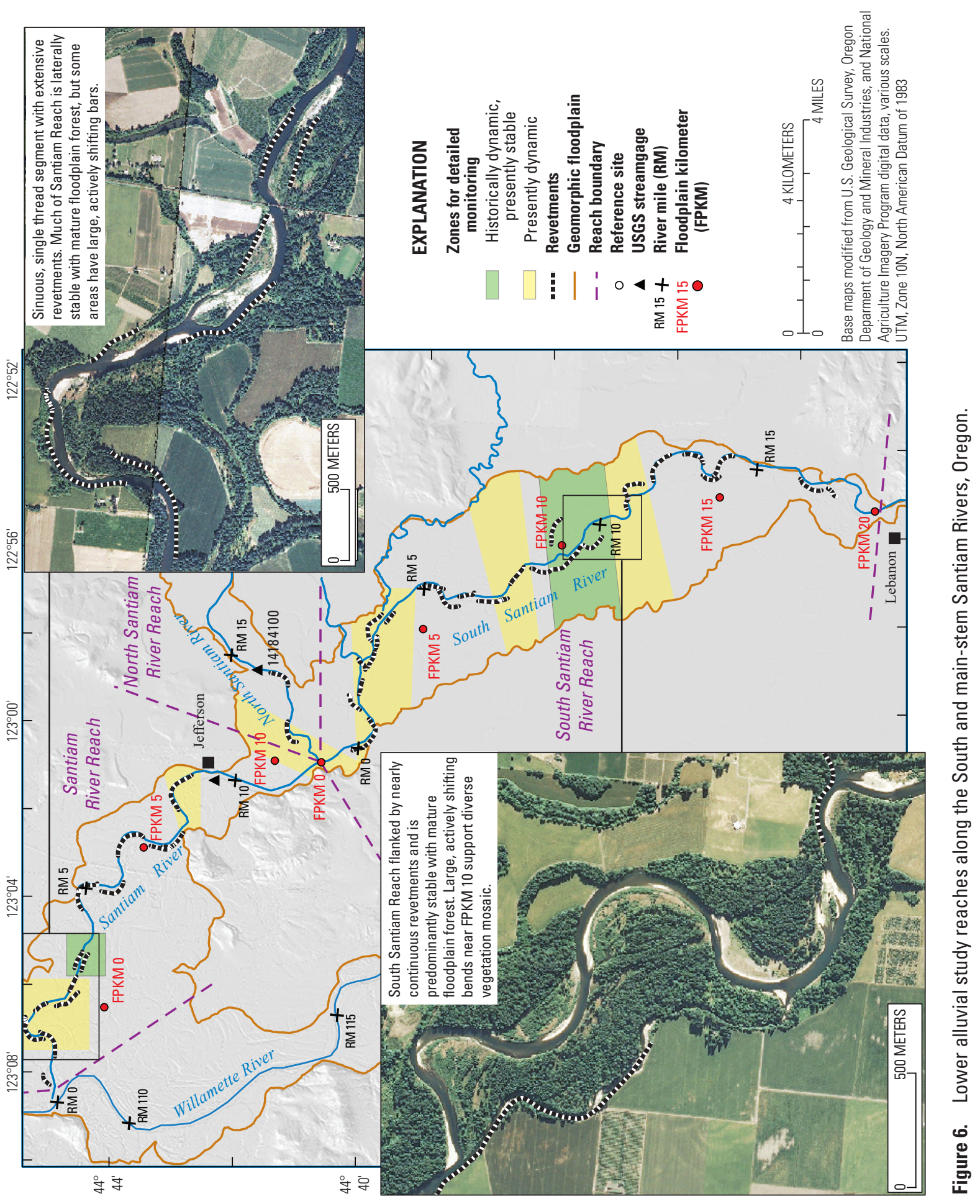




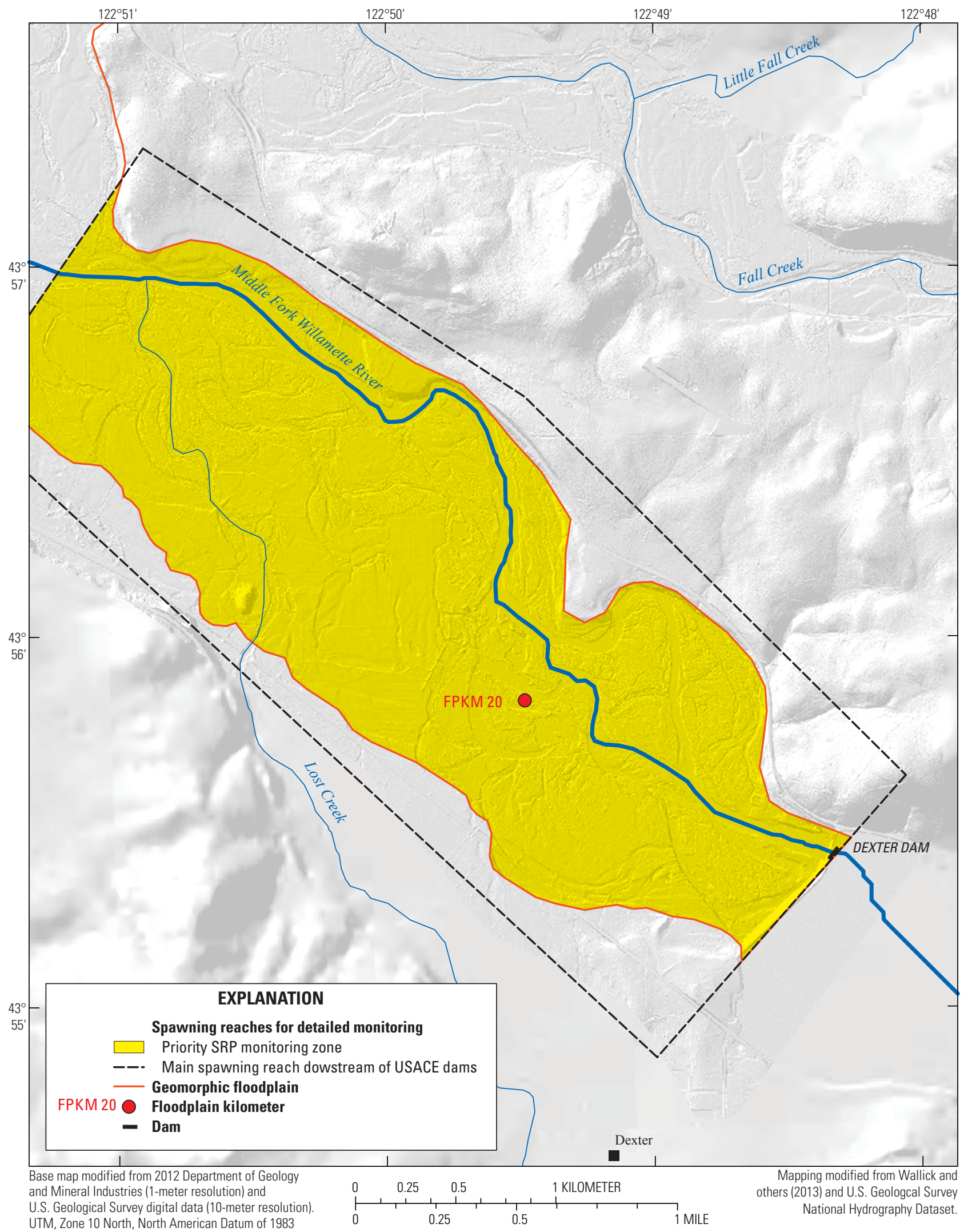

Figure 7. Spring Chinook salmon (Oncorhynchus tshawytscha) spawning reach on the Middle Fork Willamette River downstream of U.S. Army Corps of Engineers (USACE) dams, Oregon. Priority areas for detailed Sustainable Rivers Project (SRP) monitoring are highlighted and could be refined in collaboration with fisheries biologists. 


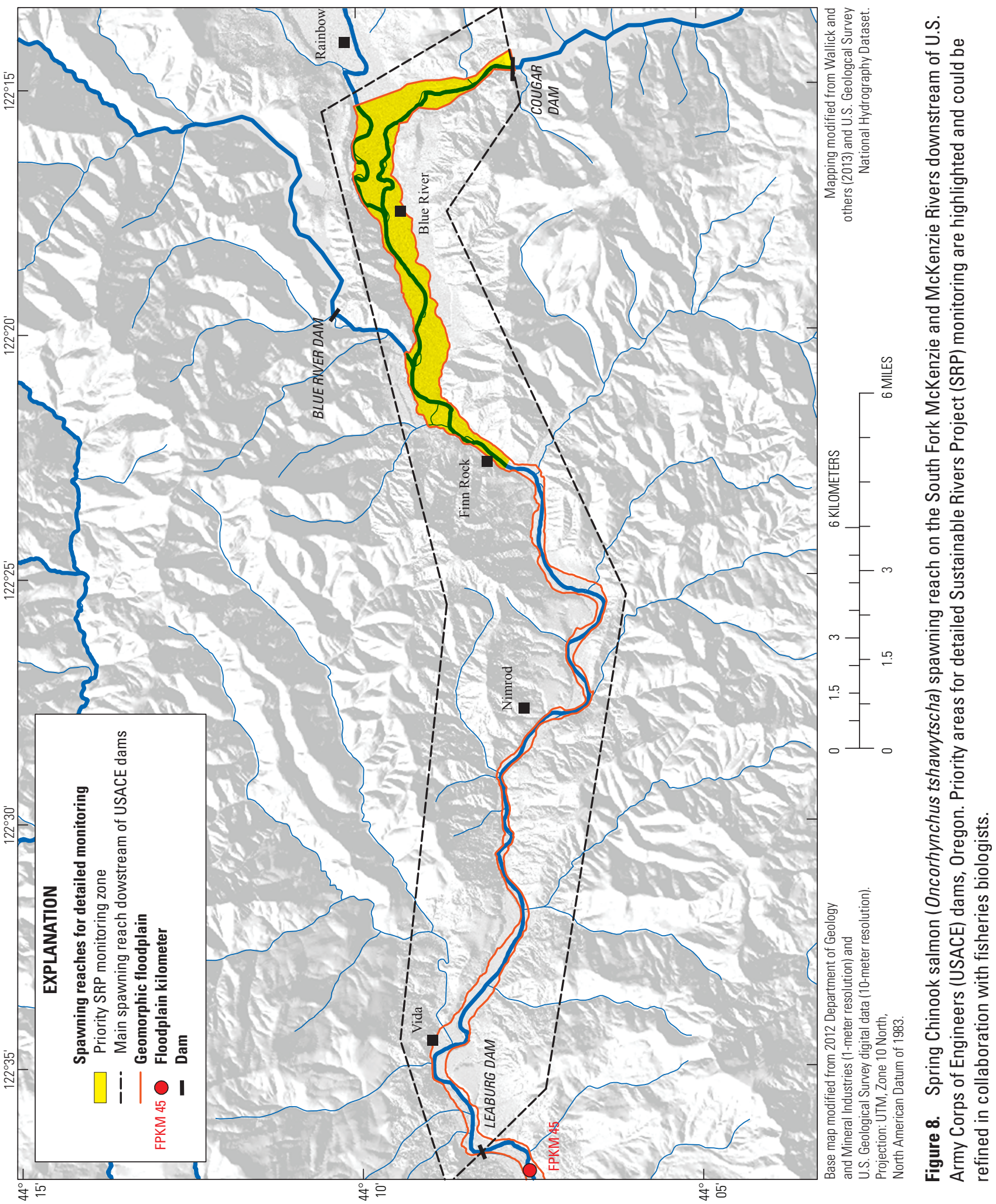




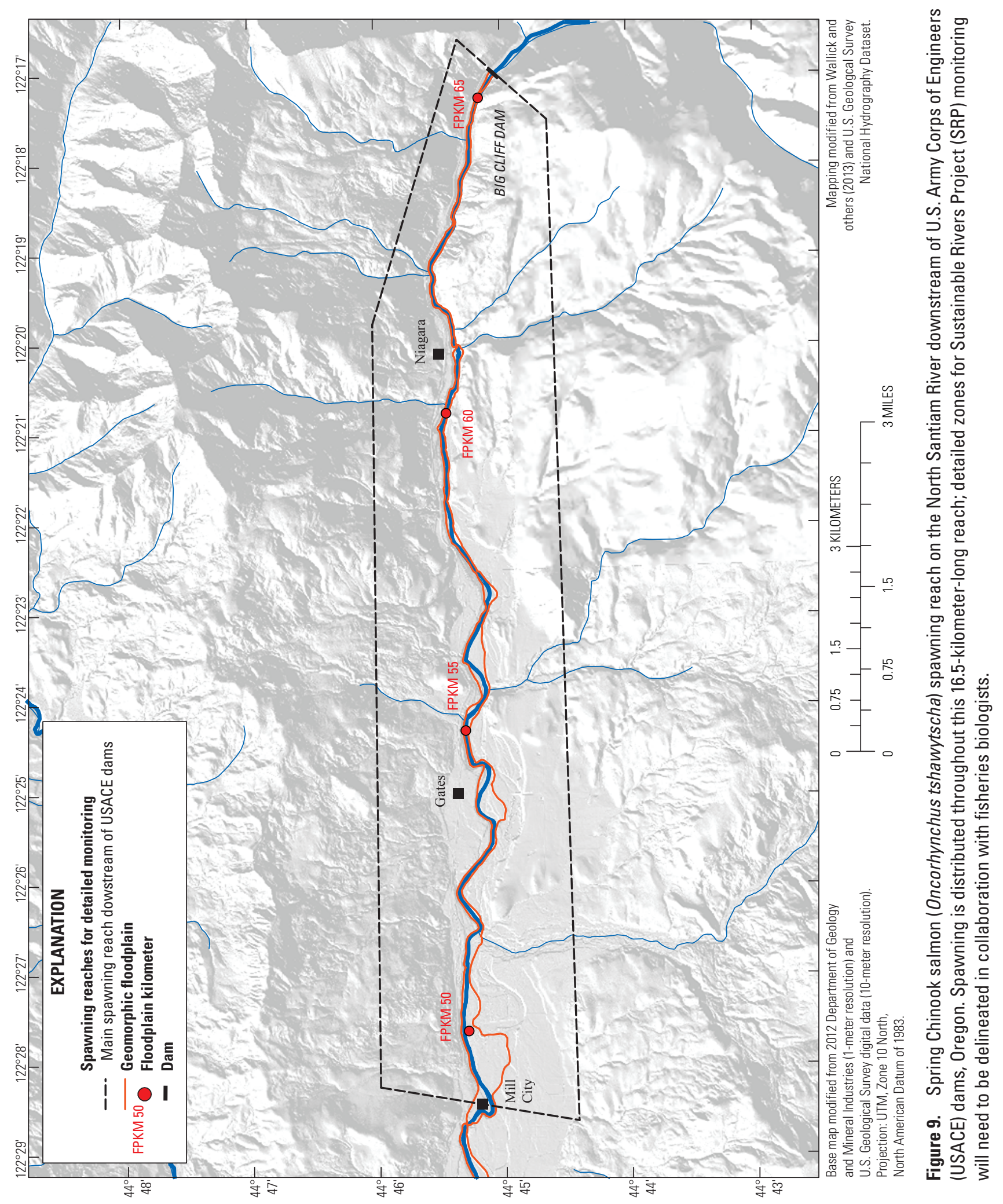




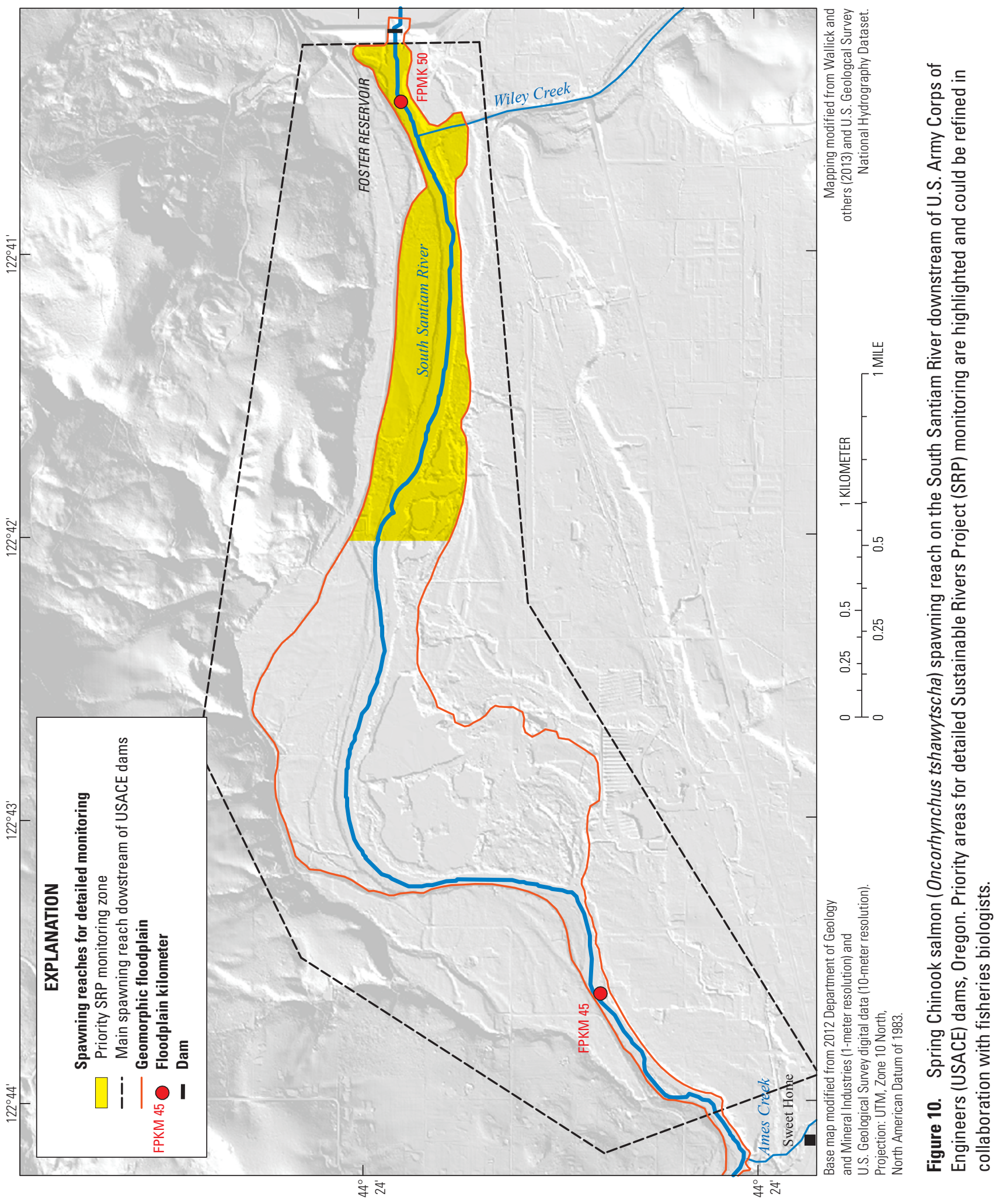




\section{Geomorphology and Riparian Vegetation, Historical Alterations, and Implications for Environmental Flows}

Historically, the lower alluvial segments of the rivers in this study contained sections of single-threaded and multithreaded channels flanked by broad, forested floodplains (Gregory, Ashkenas, Haggerty, and others, 2002; Gregory, Ashkenas, Oetter, and others, 2002). Although detailed geomorphic assessments of historical channel conditions have only been conducted for the Middle Fork Willamette River (Dykaar, 2005), historical maps from General Land Office surveys in the late 19th century (available at https:// www.blm.gov/or/landrecords/survey/ySrvy1.php) indicate that planforms along these river corridors likely included a range of morphologies including anastomosing segments (with flow divided among geomorphically stable, forested islands), wandering segments (flow divided among actively shifting gravel bars and associated log jams), and singlethread meandering segments (planform types from Church, 2002; Brierley and Fryirs, 2005). The complex assemblage of landforms, vegetation communities, and aquatic habitats of the historical river channels was created and maintained by interactions between geomorphically effective flows, slope, easily erodible bank materials, and substantial inputs of large wood and coarse sediment (Sedell and Frogatt, 1984; Benner and Sedell, 1997; Gregory, Ashkenas, Haggerty, and others, 2002; Gregory, Ashkenas, Oetter, and others, 2002; Wallick and others, 2007; Gregory, 2008).

Beginning in the late 19th century, humans have increasingly altered large wood, flow, and sediment regimes in the Willamette River Basin, thereby triggering fundamental changes in hydrogeomorphic and vegetation processes (Wallick and others, 2013). Removal of large wood, combined with diminished inputs of wood due to floodplain land conversion and upstream harvest, has altered the river systems of the Willamette Valley and contributed to losses in channel complexity (for example, Sedell and Frogatt, 1984). Floodrisk management since the mid-20th century has reduced the inundated area and the geomorphic effectiveness of presentday floods. The amount of coarse sediment entering the rivers in the study area is substantially reduced by trapping from upstream dams (O'Connor and others, 2014), and further reduced by revetments that restrict bank erosion and the subsequent liberation of sediment to the channel. Together, these alterations have resulted in more geomorphically stable river channels, with decreases in the rate and magnitude of lateral migration and avulsion, narrower corridors of habitatforming processes, substantial decreases in side-channels and gravel bars, and establishment of disturbance-dependent riparian vegetation.

The planforms and processes of the present-day floodplains are substantially different from those of the 1800 s, but still indicate historical processes. The present-day overall planform of the alluvial reaches can be characterized as those of "wandering gravel-bed rivers" (Church, 1983), with channels that are mostly sinuous, single-thread channels with landforms that are largely inherited from historical anastomosing, wandering, and meandering conditions (like those described by Surian and Rinaldi, 2003, and Rinaldi, 2003). These alluvial reaches are responsive to environmental flows because the beds and banks of the river are composed of rivertransported gravel, sand, and silt. These relatively erodible bank and bed-material sediments allow alluvial channels to respond to environmental flows through adjustments in channel morphology or substrate characteristics. Such morphological adjustments have implications for riparian vegetation and the availability of aquatic and riparian habitats because habitat features such as gravel bars and side-channels are created by bed-material transport and channel shifting. Although many locations within the alluvial segments of the study area have been stabilized by revetments, these reaches remain geomorphically active and hydraulic connections between the river and the floodplain still exist. The alluvial reaches provide year-round rearing habitat and migratory corridors for spring Chinook salmon, whereas spawning grounds are concentrated in upstream semi-alluvial reaches where gravel and cobble substrate overlays bedrock channel bed. The upstream river sections that support spawning have higher gradients than downstream alluvial reaches and, because they flow on or against bedrock, the overall channel position is stable, but the character and distribution of gravel substrate used for redd construction can vary with flow and sediment-supply conditions. Likewise, because the spawning zones are located immediately downstream of USACE dams, the depth, extent, and duration of inundation during redd incubation is directly linked with flow releases.

Although the river corridors in the study area share similarities in terms of valley characteristics, historical conditions, alterations, and present-day conditions, there also are some differences that have important implications for how each river will respond to environmental flow releases and corresponding monitoring strategies. For example, laterally dynamic sections such as the North Santiam River downstream of Stayton have little bank stabilization and have active meander migration and avulsions, resulting in larger and more numerous actively shifting gravel bars, a patchy, diverse array of vegetation stands, and more numerous sidechannels than reaches with more extensive bank stabilization (fig. 5; appendix 1). Laterally stable reaches such as the Middle Fork Willamette, South Santiam, lower McKenzie, and main-stem Santiam Rivers display minimal changes in channel position over time, with little meander migration or avulsions (table 1; figs. 3-4, 6; appendix 1). Laterally stable segments have very few actively shifting bare gravel bars, and most of the side-channels along these reaches are relict features from the historical flow and sediment regime. Most laterally stable streams flow locally against resistant bank materials (including revetments or bedrock) that constrain lateral mobility, limiting riparian vegetation to mostly mature age classes alongside the river. 
To support the monitoring approaches described later in this report, seven reaches were delineated for this study. The longitudinal extent of each reach is defined by its hydrogeomorphic and vegetation characteristics, whereas its lateral extent is defined by its "geomorphic floodplain"-or corridor of landforms and habitats that have been shaped chiefly by streamflow and sediment transport processes active during the Holocene. As summarized by Wallick and others (2013), the morphological characteristics of each reach are distinct and relate to overall differences in geology, physiography, flow, sediment transport, and bank stability. Reach characteristics are summarized in table 1, appendix 1 , and are shown in figures 3-6.

Many surfaces within the geomorphic floodplain are vegetated with plant species that are dependent on fluvial processes and landforms. In sections where the channel is actively migrating or experiencing avulsions, floodplain forests are composed of "pioneer" species such as black cottonwood, willow (Salix spp.), and white alder (Alnus rhombifolia) that colonize recently deposited gravel bars, whereas mature black cottonwood, Oregon ash (Fraxinus latifolia), and bigleaf maple (Acer macrophyllum) tend to occupy older, high-elevation surfaces.

This study focuses on hydrogeomorphic and vegetation processes within the geomorphic floodplain. We use the geomorphic floodplain for this monitoring framework because it encompasses the diverse array of floodplain habitats that support different life stages for a variety of aquatic, riparian, and terrestrial organisms. The geomorphic floodplain also provides a static reference frame from which to measure future changes in floodplain landforms and habitats. For each river in the study area, the geomorphic floodplains and floodplain kilometer (FPKM) reference systems of Wallick and others (2013) are applied, where numbering begins at the mouth of each river and continues upstream (figs. 3-6).

This framework describes monitoring approaches for two primary areas of the geomorphic floodplain that are influenced by the present-day flow regime:

1. Active channel areas that are subject to frequent scour, bed-material transport, and sediment deposition during floods. Landforms within the active channel primarily are underlain by coarser gravel and sand and may include:

- Primary (wetted) channel;

- Secondary channel features (such as side-channels and alcoves);

- In-channel elements such as pools and riffles;

- Gravel bars with sparse-to-dense vegetation, ranging from bare, actively shifting bars to more stable bars with dense shrubs, and including both attached bars (for example, point bars) and mid-channel bars; and
- Islands that typically are more stable landforms with mature forest or other evidence of stability across several decades.

2. Near-channel floodplain areas that are subject to occasional overbank inundation and fine sediment deposition during present-day floods. Floodplain surfaces are higher in elevation than active channel features, and are mantled with finer sands, silt, and clay transported as suspended load. Floodplain landforms include:

- A continuum of channel features (side-channels, sloughs, ponds, swales), and

- Natural levees formed alongside the river channel and broad planar surfaces separating channel features.

\section{General Monitoring Framework Considerations}

Monitoring hydrogeomorphic and vegetation responses to environmental flow releases requires consideration of the spatial and temporal scales of monitoring activities and evaluation of hydrograph characteristics. The overall monitoring approach is similar for reaches in the study area. However, some consideration of reach-specific conditions will be needed when establishing basin-wide priorities and developing reach-specific monitoring plans (appendix 1). Because many of the individual monitoring approaches described in this report can be used to evaluate multiple hydrogeomorphic and vegetative responses, considerations for minimizing measurements while maximizing findings also are integrated throughout the framework (appendix 1). General monitoring considerations that should be integrated in environmental flow monitoring efforts are outlined in the subsections that follow.

\section{Spatial and Temporal Scales of Monitoring Activities}

Flow recommendations encompass a range of environmental flow components that are each intended to produce distinct hydrogeomorphic or vegetation responses relating to ecological goals. Evaluating whether ecological goals are met will entail deploying suitable monitoring activities at locations where these responses are likely to occur and collecting monitoring data at the appropriate spatial and temporal scales to evaluate the underlying process of interest. For each expected hydrogeomorphic or vegetation 
response to a particular environmental flow component, we identify the geomorphic domain for this response (active channel compared to floodplain) and the specific landform or landforms of interest. For example, fall pulse flows are intended to inundate the margins of the active channel, specifically secondary channels. In this example, monitoring activities would focus on measuring inundation in secondary channels within the active channel.

Once there is a clear linkage between a particular environmental flow component and the location of anticipated responses within the geomorphic floodplain, an appropriate spatial scale for the monitoring activity can be selected. In this monitoring framework, we focus on three spatial scales of data collection-reach-scale monitoring, zone-scale monitoring, and site-scale monitoring (fig. 11):

1. Reach-scale monitoring generates comprehensive data across an entire reach (10-30 km in length), which is useful for assessing longitudinal trends on an infrequent basis. The reaches and their associated monitoring approaches align established SRP flow targets and corresponding river segments where those targets were defined (appendix 1). There are two types of reaches defined in this framework:

- Alluvial reaches encompass the lower segments of each river corridor between their upstream canyons and the confluence with the Willamette River. These reaches have a more complex array of habitats and vegetation communities than more intrinsically stable river segments located in upstream canyon areas (figs. 3-6).

- Spawning reaches are focused immediately downstream of USACE dams, where most of the present-day spawning by spring Chinook salmon occurs (figs. 7-10; National Marine Fisheries Service, 2008).

2. Zone-scale monitoring entails application of reachscale approaches within short $(0.5-2 \mathrm{~km})$, highpriority sections of the floodplain where site-scale measurements also are focused. The monitoring zones identified in this study are suitable for frequent, in-depth monitoring because the zones are shorter than reaches (and can be more efficiently monitored) and the hydrogeomorphology and vegetation in these areas are more sensitive to environmental flows than areas that are geologically stable or stabilized with revetments. These monitoring zones also encompass areas with a more complex assemblage of habitats than other sections of the study area. Candidate monitoring zones are identified in figures 3-6 and appendix 1, and are divided into two categories:
- Laterally dynamic monitoring zones have channels with actively shifting gravel bars and side-channels, indicating frequent geomorphic adjustments in response to annual high flows.

- Laterally stable monitoring zones historically encompassed multi-threaded channels that underwent lateral migrations or avulsions as evidenced by relict side-channels flanked by mature vegetation and large forested gravel bars. The mature vegetation in these zones indicates they have not been reworked in recent decades because of flood reduction. These areas potentially could respond dynamically to future flood events because they lack revetment and are flanked by erodible, lower-elevation floodplain surfaces.

3. Site-scale monitoring takes place along static transects or small areas or points within the geomorphic floodplain (fig. 11). Site-scale monitoring generally is focused within monitoring zones, and when sites are established in multiple locations along a reach, they would aid in understanding longitudinal trends and could be used to identify areas where more detailed analyses are needed.

Hydrogeomorphic and vegetation processes occur over different timescales; therefore, the timing and frequency of data collection for monitoring activities described in this framework is needed. For example, some responses to environmental flows are immediate (such as inundation) and may entail frequent, year-round data collection. In contrast, other responses are more gradual (such as vegetation succession) and could be characterized by infrequent data collection every few years. Additionally, the timing of some monitoring activities is linked with flow conditions or safety considerations. For example, it is safest and most efficient to characterize bed-material substrate during low-flow periods when gravel bars are exposed. For each of the monitoring activities, we provide general guidance as to the timing and frequency of data collection, which can be used to refine more specific monitoring plans for a particular reach.

\section{Evaluating Streamflow Targets}

The flow recommendations for each river in the study area are composed of multiple environmental flow components, each of which has specific streamflow targets describing the magnitude frequency, duration, and timing of flow releases to support ecological goals (table 2). Comparing observed streamflows with these flow targets provides a basis for validating flow releases from dams and determining the degree to which various streamflow targets were achieved. Streamflow data also provide a critical foundation for interpreting hydrogeomorphic and vegetation responses that are the focus of the monitoring program. Hydrograph information also can be used to better understand hydrologic processes such as rate of change of flow conditions, which is important to fish survival and other aquatic species. 


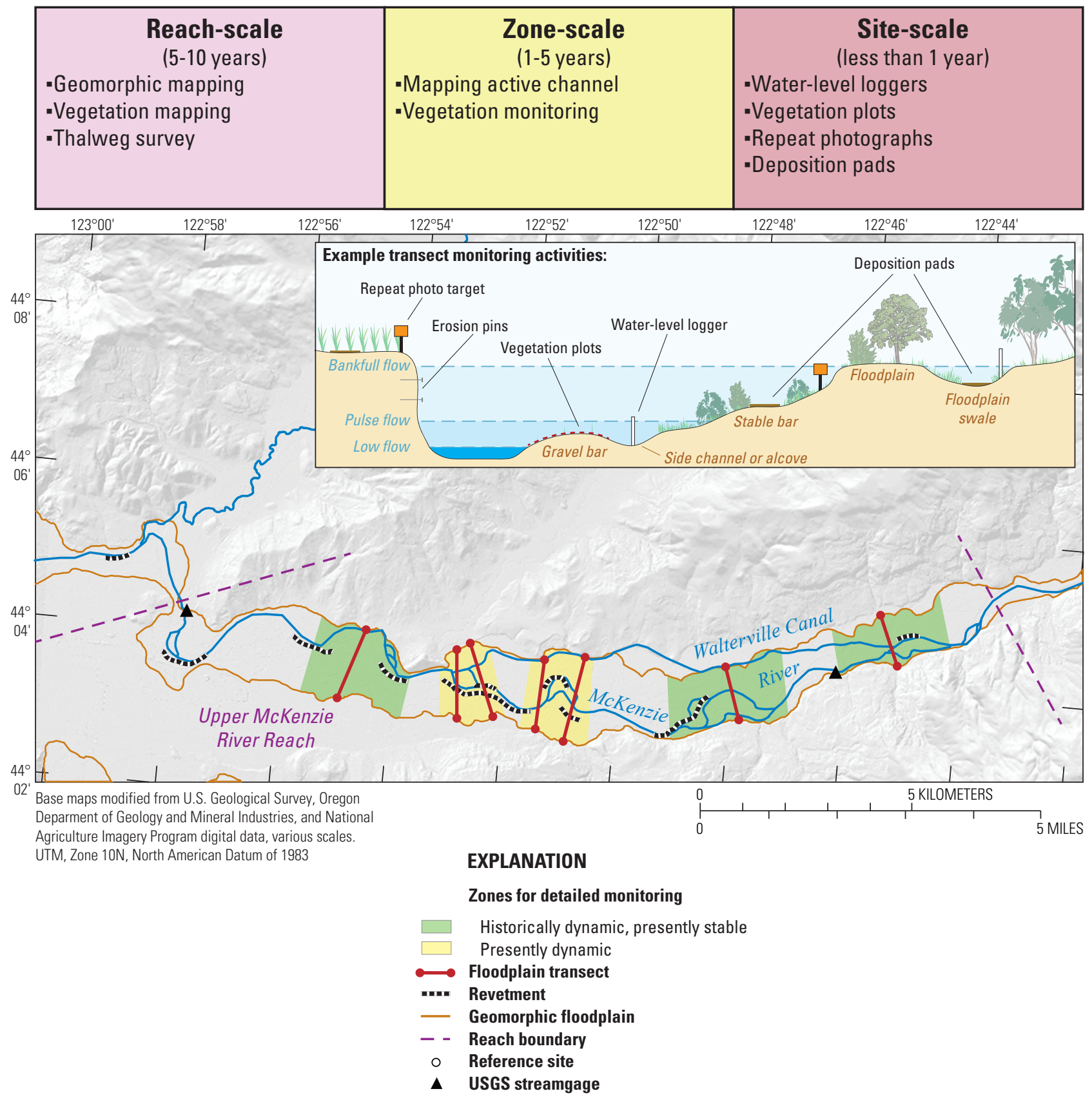

Figure 11. Map and transect example showing reach, zone, and site-scale monitoring activities and associated measurement frequencies for McKenzie River, Oregon. Hypothetical monitoring transect shows monitoring activities to assess hydrogeomorphic and vegetative responses to environmental flows. 


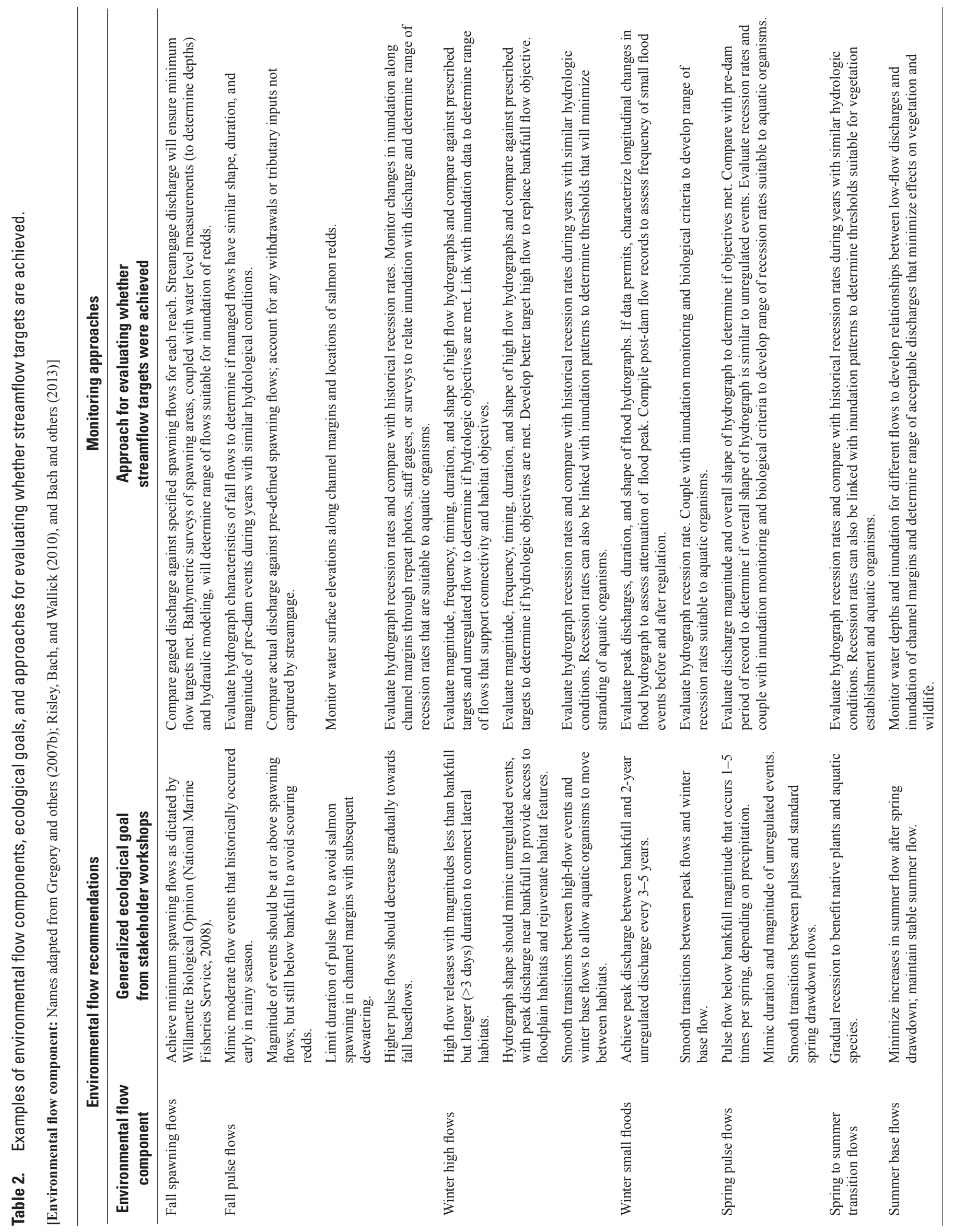


Evaluating the extent to which actual flows met streamflow targets can be carried out using the USGS streamgages located in, or near, each reach and the targets described for each basin (appendix 1; Gregory and others, 2007b; Risley, Bach, and Wallick, 2010; Bach and others, 2013). At some locations, withdrawals for municipal or irrigation use also must be considered, especially during low flow periods when such withdrawals are likely to more substantially influence streamflow in the reach (appendix 1). Specific approaches for evaluating hydrologic characteristics and implementation of the environmental flow program are summarized in table 2 , and described more fully in appendix 2 .

\section{Research to Refine Environmental Flow Recommendations}

The streamflow and ecological relations that are the basis for the environmental flow recommendations currently are not well defined for the Willamette River tributaries. In many cases, the existing flow-ecology relations (Gregory and others, 2007b; Risley, Wallick and others, 2010; 2012) are based on limited existing data, qualitative observations, and the best judgement of SRP stakeholders. Limited understanding of flow-ecology relations potentially could have negative consequences for SRP stakeholder priorities. For example, some flow objectives may not be realistic or some flow objectives could have negative effects on riparian ecosystems they are intended to enhance. To better support SRP stakeholder priorities, the existing flow-ecology relations could be improved through additional research and evaluation to ensure that each flow objective is based on sound scientific relations between streamflow and the ecosystem objective of interest. There are numerous outstanding research questions (appendix 3) that, when addressed, will provide important data and information for refining the flow recommendations.

\section{Development of a Monitoring Plan and Leveraging Data Collection Across Multiple Organizations}

Considering the large spatial extent of the study area and the many stakeholders (including watershed councils, land trusts, and local and Federal governments, as outlined in appendix 4) that are actively engaged in floodplain restoration and habitat monitoring within this area, there are many opportunities to leverage resources and distribute data collection and monitoring activities. Wherever possible, this report notes known instances where datasets and approaches like those described herein are already being collected in the study area.

According to Higgins and others (2011), a detailed monitoring plan is a critical component part of the environmental flow monitoring program and should describe the following:

- What is being monitored, and how data collection relates to recommendations, flow conditions and dam operations.

- Multi-organizational strategy for data collection (who is measuring what, when, where, and the roles and responsibilities for each organization).

- Specific strategies for each phase of the monitoring program including evaluating program implementation, determining short-term responses to environmental flow releases, and evaluating long-term status and trends.

- Methods and protocols for data collection and procedures for implementing quality assurance and quality control.

- Site-specific issues relative to local dam operations and water-management decisions.

- Analyses to interpret monitoring data and place findings within broader context of flow management (Higgins and others, 2011). Analyses could include steps for (1) evaluating the role of environmental flows from other natural and anthropogenic factors influencing changes in monitoring indicators, and (2) determining natural variability compared to systematic change in conditions.

Well-defined protocols are essential for ensuring consistent data collection over time and across different reaches of the study area. Some protocols, especially those for geomorphic mapping and sediment-size characterization, are well-documented and ready for broader implementation, but protocols for other tasks, such as evaluating recession rates and vegetation recruitment, will need to be defined. Prior to implementation of the monitoring plan, all protocols should be clearly described and publicly available. 


\section{Monitoring Hydrogeomorphic Responses to Environmental Flows}

Hydrogeomorphology is an interdisciplinary science that focuses on the interaction and linkage of hydrologic processes with landforms or earth materials and the interaction of geomorphic processes with surface and subsurface water in temporal and spatial dimensions (Sidle and Onda, 2004). As streamflows change, there are corresponding changes in watersurface elevations or water-surface elevation and lateral extent that vary with the geomorphic characteristics of the river and floodplain. Changes in flow, together with changes in sediment supply and large wood, create adjustments in river planforms, bed elevations, bed textures, and floodplain surfaces (fig. 12). These responses vary spatially according to inputs of flow and coarse sediment, which dictate the relative balance between transport capacity - the "maximum load a river can carry" (Gilbert and Murphy, 1914, p. 35) - and bed-material supply.

Geomorphic responses also will vary with factors such as geology and physiography, which control largescale patterns of bank erodibility, valley width, and valley slope, thereby mediating channel changes. In the study area, geologic controls include the distribution of resistant bedrock outcrops and Pleistocene terraces that limit lateral changes in channel planform. Revetments also impart local channel stability, whereas reaches flanked by erodible Holocene alluvium can respond more dynamically to changes in flow or sediment supply. Because it can be challenging to establish clear linkages between environmental flows and resulting morphologic adjustments, other factors such as sediment supply and bank erodibility must be considered.

In gravel-bed rivers such as those of the study area, the term "geomorphically-effective flows" refers to streamflows that can transport bed-material sediment, a crucial threshold for initiating a wide range of geomorphic responses. Geomorphically effective flows currently are undefined for the study area but typically have recurrence intervals exceeding 1 year (Andrews, 1983, 1984). For gravel-bed rivers, geomorphically effective flows typically are correlated with bankfull flows, but can vary with the grain size of bed-material sediment and channel slope (for example, Andrews and Nankervis, 1995; Emmett and Wolman, 2001). Because bed-material transport is required for gravel-bed rivers to create and rejuvenate fluvial habitats, we focus our discussion of changes in channel morphology and bed texture on geomorphically effective flows rather than specific environmental flow components (such as bankfull flows or small floods) for which the geomorphic responses are currently unknown. However, findings from a monitoring program eventually could support linkages between hydrograph characteristics, (such as magnitude and duration of high flow events) and associated geomorphic responses, which could support refinement of flow targets for bankfull flows and small floods. For this monitoring framework, we summarize methods for detecting changes in water-surface elevation and inundation patterns, channel pattern and planform, channelbed elevation, bed-material texture, and floodplain landforms, as well as specific methods that apply to redd dewatering and scour in spawning reaches (fig. 12; table 3 ).

\section{Approaches for Monitoring Water-Surface Elevations and Inundation}

Water-surface elevations along with water depth, spatial and temporal extent of inundation, and activation of secondary channels and other habitat features, vary in response to specific flow characteristics and geomorphic changes in underlying channel morphology (table 2). This has important implications for habitat availability, species movement and life-history patterns, and water-quality conditions. Fall flows dictate the amount and suitability of spawning habitat for salmon and control the depth of water over redds. Winter high flows inundate the floodplain and allow species movement into side-channels. Spring flows, including rate of change, control downstream migration of salmon and access to off-channel habitat. Summer flows provide rearing habitat and influence water-quality conditions such as temperature. The approaches that follow describe techniques for monitoring water-surface elevation and inundation for different flows.

The approaches outlined here use a combination of site-, zone-, and reach-scale measurements for tracking lateral and longitudinal variation in flow depths and inundation extents (tables 2,3). Each of the methods selected here was used in the Willamette River Basin and has proven to be efficient, reliable, and cost-effective. The datasets and approaches described here also could be used to understand vegetation responses (see section, "Monitoring Riparian Vegetation Responses to Environmental Flows").

Site-based methods for assessing water-surface elevations, depths, and inundation extent at individual transects include the following:

- Measuring water-surface elevations and depths using repeat ground-based surveys. This method is the most expedient means to evaluate water levels and inundation extent for a range of flows and is particularly useful in areas where channel bed elevations may be changing frequently owing to scour or deposition. The edge of water, water-surface elevation, and depth of shallow areas can be surveyed directly if conditions allow (such as during low or moderate flows). In instances when it is impractical to directly survey the water surface (such as floods), flagging, pin flags, or other monuments can be used to note high water marks that can be surveyed later. If the channel bed is relatively stable (for example, if it consists of very coarse substrate or bedrock), surveying activities can focus on water-surface elevations. 


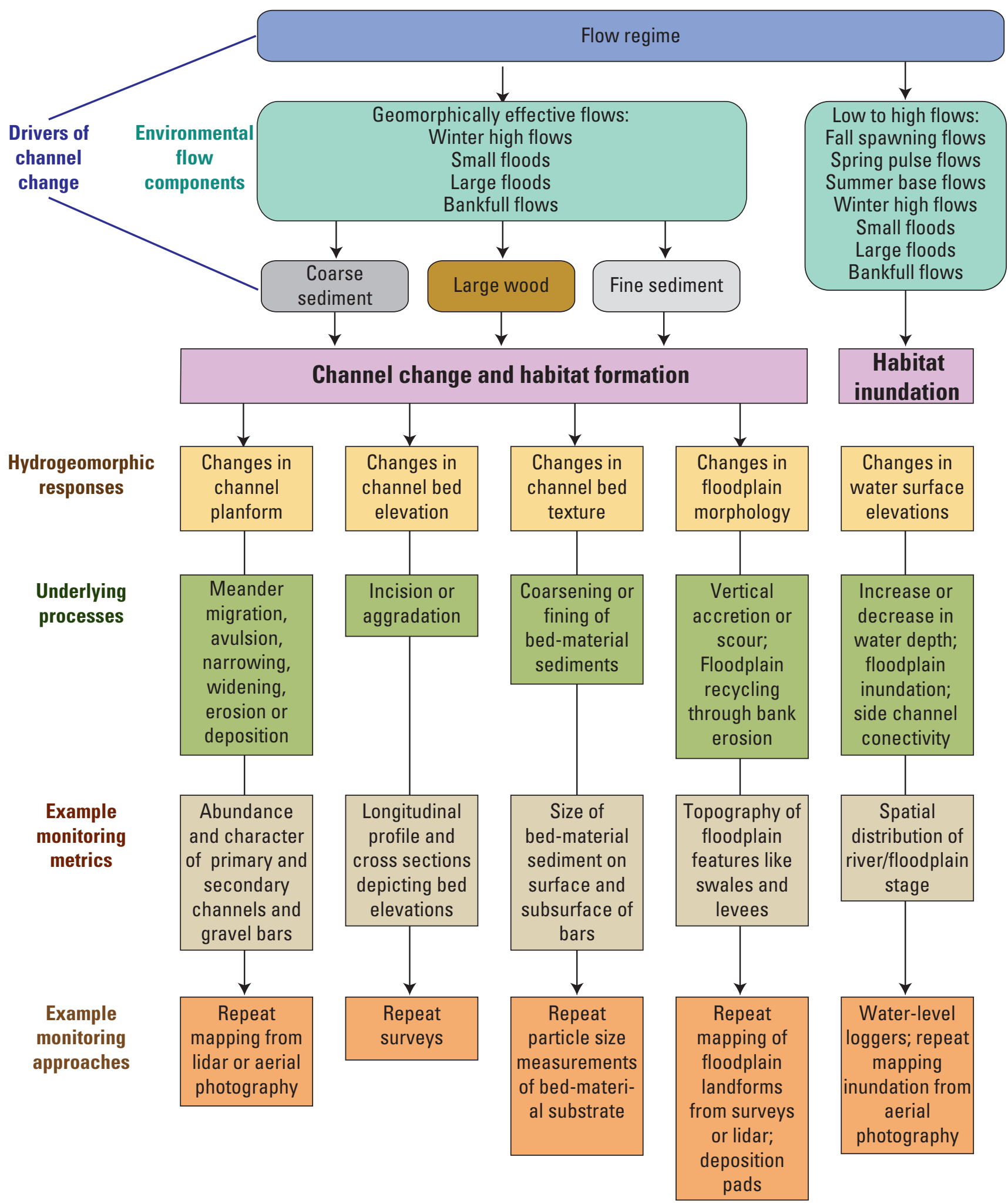

Figure 12. Conceptual model of hydrogeomorphic responses to environmental flows and approaches for monitoring these responses in gravel-bed rivers downstream of U.S. Army Corps of Engineers dams in the Willamette River Basin, Oregon. 


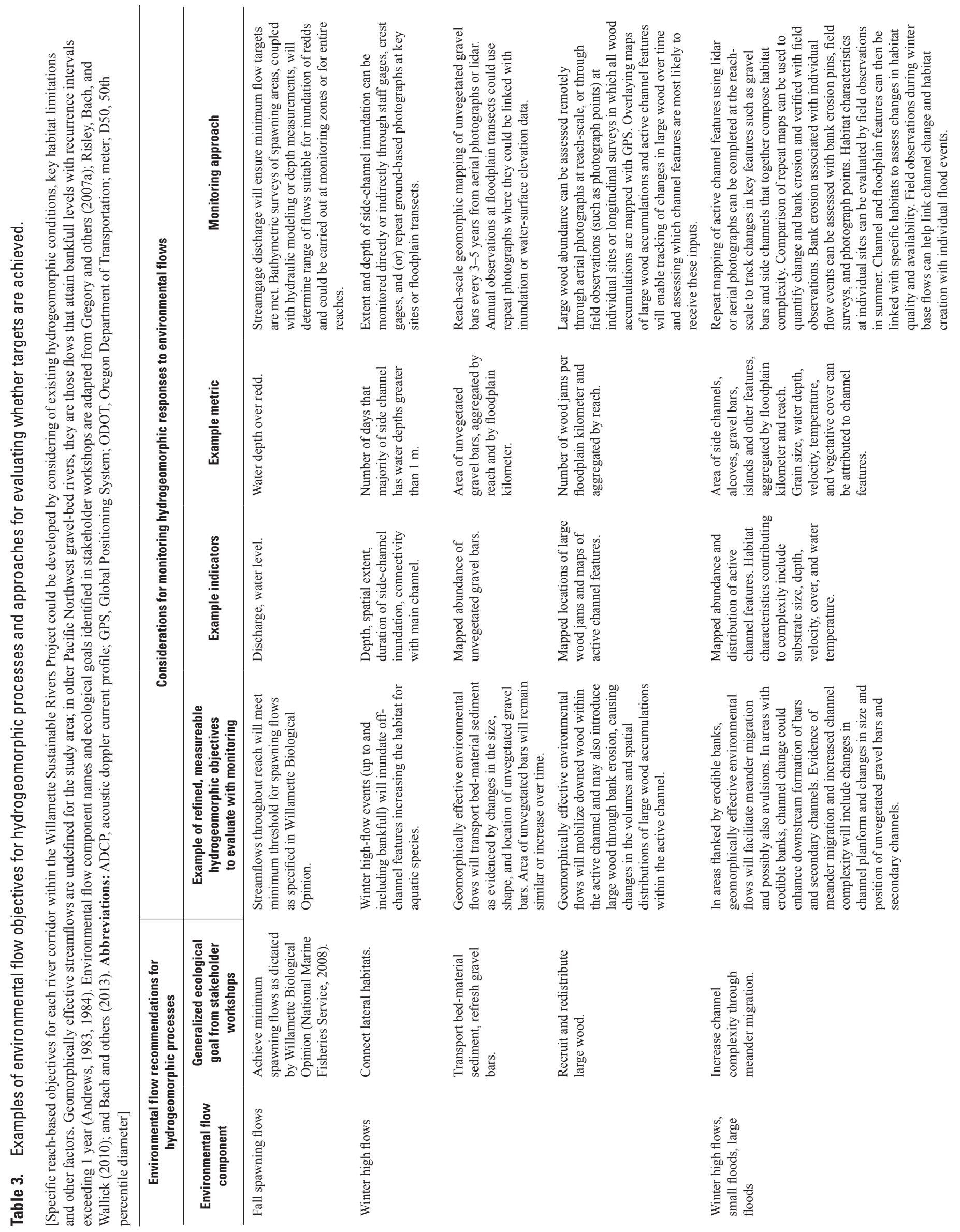




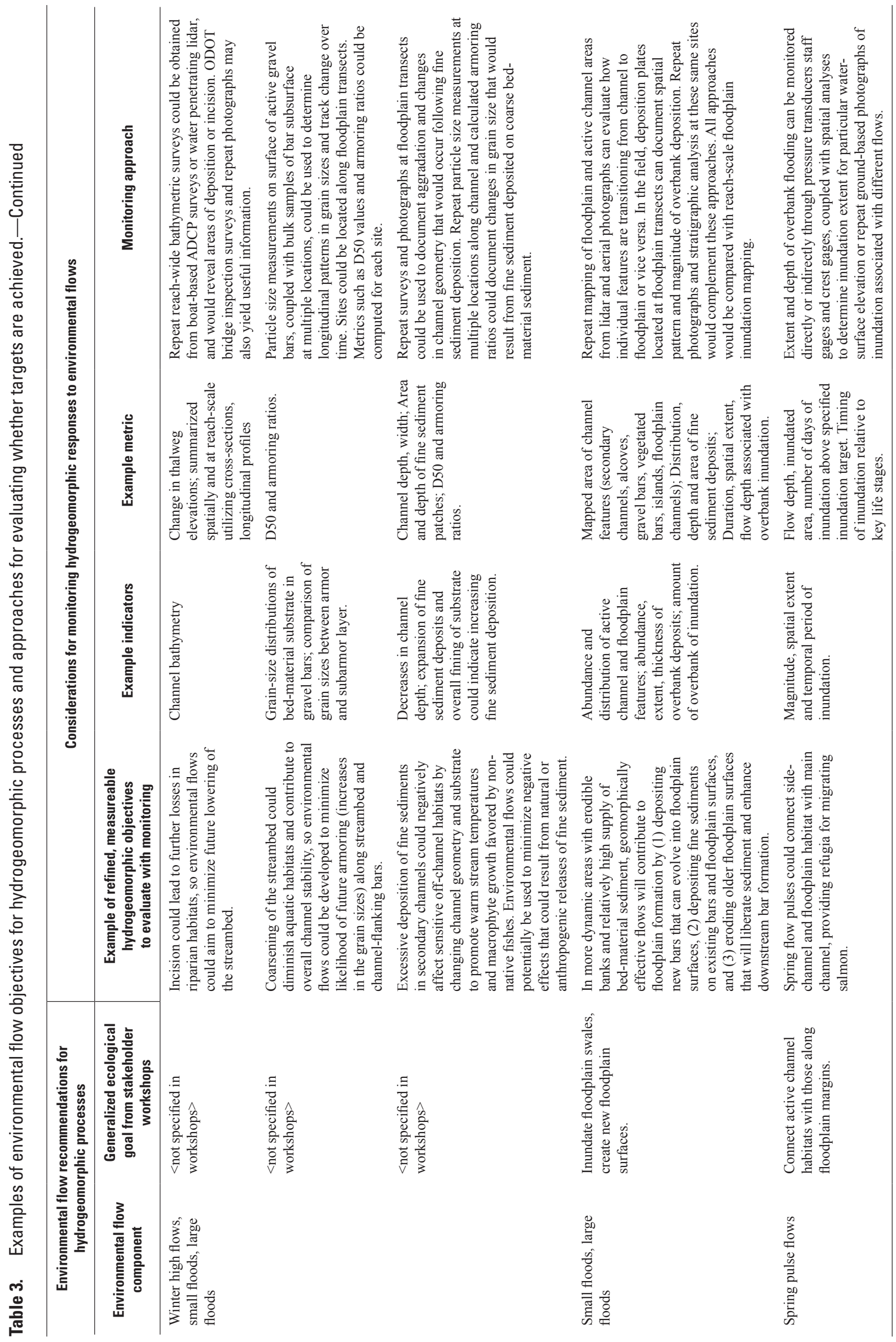


- Recording maximum river stage using crest stage gages at a particular location. This method is especially useful for obtaining high water marks along infrequently inundated side-channels, sloughs, and floodplain areas. Crest stage gages also can be placed in more frequently inundated areas, but will require multiple site visits to determine flow-stage relations. Crest stage gages should be surveyed upon deployment and collection to provide accurate locations for long-term monitoring and should provide a basis for converting stage to water-surface elevation.

- Monitoring continuous variation in water-surface elevations to determine timing and duration of inundation using water-level loggers. A network of water-level loggers located at 2-10 km intervals along a reach would provide characterization of spatial and temporal variation in water-surface elevations and stream temperatures (useful for characterizing habitat suitability for fishes) and provide critical data for calibrating hydraulic models. Water-level loggers should be surveyed upon deployment and re-surveyed during seasonal site visits when the data are downloaded to determine if the instrument moved during while deployed (Freeman and others, 2004). Data collection and processing steps are well documented (for example, Freeman and others, 2004) and follow similar methodologies as other Willamette River datasets (for example, Mangano and others, 2018).

- Photographing inundation at a wide range of flow conditions from fixed cameras on timers or during site visits. Photographs provide an indirect method for tracking changes in stage and inundation over time. Pre-established photograph points should contain a large, immobile target from which to reference repeat photographs (Shaff and others, 2007). If each photograph is attributed with a date and time, repeat photographs provide a platform for assessing qualitative differences in river stage at different discharges. More quantitative techniques such as "Structure from Motion," in which digital elevation models are constructed from photographs, provide a basis for measuring variation in watersurface elevations from repeat photographs (Major and others, 2012; Fonstad and others, 2013; Mosbrucker and others, 2017). The primary drawback to repeat photographs is that they must be taken during daylight hours and, unless fixed cameras are installed, the sites must be visited during the flow events of interest, requiring that the site be safe and accessible.

In conjunction with site-scale measurements, reach-scale characterization of water-surface elevations, depths, and inundation extent could be carried out using the following approaches:
- Delineating the wetted channel from aerial photographs acquired at different flow conditions. Repeat mapping from photographs could be carried out efficiently using publicly available photographs, such as digital orthophotographs generally acquired every 2-3 years by the National Agricultural Inventory Program during low-to-moderate flows (Wallick and others, 2010; 2011). The resulting maps would provide a basis for examining reach-scale inundation at a variety of discharges and could be paired with the surveyed transects to infer variation in flow depth and inundation at floodplain-monitoring transects.

- Commissioning aerial photography to coincide with peak discharge in the event of a particularly large flood or other flood event of interest. This information can be used to document reach-scale patterns of inundation. The aerial photographs would need to be rectified and georeferenced, and flooded areas digitized, but the resulting datasets would be useful for evaluating reach-scale inundation patterns across a broad area and could inform a broad range of floodplain-management issues.

- Surveying water-surface elevations and flow depths from boat-based longitudinal profile surveys. A highly accurate and efficient way to measure flow depths and water-surface elevations along long reaches is through longitudinal profile surveys, in which a boat is equipped with survey-grade Global Positioning System (GPS) to record boat position and watersurface elevation and an echo sounder to measure flow depths. Depending on river conditions, boat-based surveys can measure $10-40 \mathrm{~km}$ of river channel in a single day and could be repeated for several distinct flows of interest. The resulting datasets would provide information needed to understand longitudinal variation in flow, water-surface elevation, and depth along reaches. Additionally, the longitudinal profile surveys can be paired with cross-section surveys in areas of interest (such as floodplain-monitoring transects or critical habitat features) to evaluate lateral variation in flow depth for different discharges.

- Other tools to understand water-surface elevations and inundation extent. Analysis of streamgage rating tables and development of hydraulic modeling are beyond the scope of monitoring. However, these techniques could inform the monitoring described in this report and could lead to more rapid, cost-effective, and useful data collection. Because it is technically challenging and expensive to accurately monitor inundation and water-surface elevations on large rivers such as those in the study area, these techniques offer potentially cost-effective ways to quantify watersurface elevations and inundation. 
- Mapping reach-wide patterns of inundation at different discharges using USGS streamgage rating tables, discharge data, and observed watersurface elevations to create water-surface elevation prediction trendlines (also referred to as a "bath tub" analysis). The resulting water-surface elevations can be overlain on lidar topographic surface models to create inundation maps. Such analyses have already been completed for the 2-year recurrence interval flow in the McKenzie and Middle Fork Willamette Rivers (River Design Group, Inc., 2012, 2013), are underway for the Santiam River Basin (River Design Group, 2017) and could be repeated for other streamflows.

\section{- Using hydraulic models to develop relations} between streamflow, water-surface elevations, and inundation extent. One- and two-dimensional models can be used to evaluate reach-wide inundation patterns at different flows to record incremental changes in water elevation relative to discharge. For example, one-dimensional hydraulic models can be used to examine variation in stage and channel width for flows confined within the channel banks (generally for flows as high as the bankfull flow), whereas two-dimensional hydraulic models more accurately characterize overbank flooding and side-channel connections in unconstrained floodplains. Many of the datasets needed to develop hydraulic models are available in the Willamette Valley. For example, lidar is available for the entire study area, and each reach has adequate streamgage information. Bathymetric data are the primary limitation to developing hydraulic models of the study area, as the availability and resolution varies for each reach, but data gaps could be filled using the methods described in this report (see section, "Approaches for Monitoring Channel Bed Elevation”).

\section{Approaches for Monitoring Channel Pattern, Planform, and Large Wood}

In response to geomorphically effective flows, coarse sediment transport, and eroding bank materials, the rivers of the study area could move laterally across their floodplains through gradual meander migration, meander cutoff, abrupt channel avulsions, and braiding (for example, Dietrich and Smith, 1983; O'Connor and others, 2003; Wallick and others 2006, 2007, 2013). Over time, lateral migration and avulsions will lead to creation and subsequent abandonment of gravel bars, side-channels, sloughs, and swales. Accordingly, changes in channel position often are accompanied by adjustments in the size and position of other channel features. Changes in channel width may, or may not, accompany channel shifting but generally indicate changes in streamflow regime or sediment supply. In alluvial sections with erodible bank materials and abundant gravel bars, geomorphically effective flows could mobilize bed-material sediment, enhance meander migration, and contribute to the formation of large wood jams, gravel bars, side-channels, islands, and other features that support complex habitats (table 3, appendix 1).

The most expedient method for monitoring changes in channel and floodplain planform is through repeat mapping from aerial photographs and lidar. Repeat mapping documents changes in channel features and associated habitats that signify geomorphic processes associated with certain flow regimes. For example, bare gravel bars provide early-summer rearing habitat for juvenile spring Chinook salmon and could be mapped repeatedly from aerial photographs to evaluate how these features and associated vegetation communities respond to years with multiple high-flow events compared to years with lower-magnitude peak flows. The protocols for detailed geomorphic mapping of floodplain landforms in gravel-bed rivers of western Oregon are well established and could readily be applied to the rivers of the study area (Jones and others, 2011; Jones, Keith, and others, 2012; Jones, O'Connor, and others, 2012a, 2012b; 2016; Wallick and others, 2010, 2011, 2013). Ideally, this mapping could be carried out with similar protocols across each river in the study area to permit assessments across river corridors, but some protocols also could be tailored according to channel type and reach condition to account for habitat features of interest and the geomorphic processes that support those habitats (appendix 1). Indicators of channel dynamism and habitat availability include the diversity and abundance of large wood jams, and actively shifting bars and secondary channels, which together support a diverse array of species and life history strategies (for example, Schroeder and others, 2015). Because repeat mapping generally is carried out using photographs or lidar spanning 3- to 10-year intervals, analyses of channel changes should be coupled with flow analyses for the intervening period to establish relations between attributes of the flow regime and associated geomorphic responses. A monitoring program for measuring these features and tracking overall indicators for channel conditions, including metrics such as side-channel and bare gravel bar location and size, is summarized in table 3 and includes the following components:

\section{- Repeating reach-based mapping from lidar every} 5-10 years (or following a large-magnitude flood). The detailed lidar-based mapping could be carried out in conjunction with floodplain mapping (described in section, "Approaches for Monitoring Floodplain Landforms") and provides a basis for quantifying volumes of erosion and deposition that relate to gains and losses in important habitat features; for example, erosion that results in creation of new side-channels or deposition within a side-channel that limits direct surface water connection to main channel. 
- Repeating mapping of the active channel every 1-3 years (or following a large-magnitude flood) from publicly available orthophotographs. This more frequent mapping is necessary for linking channel change with specific flood events. The repeat mapping from air photographs ideally would be done for entire reaches but also could be constrained to focus on monitoring zones. For example, metrics could focus on changes in the unvegetated gravel bar area or active channel width, which are the parameters most likely to vary considering present-day channel stability.

- Repeat mapping of large wood jams every 1-3 years (or following a large-magnitude flood) from publicly available aerial photographs and field mapping. Large wood abundance can be assessed remotely through aerial photographs at reach scale, or through field observations at individual sites or longitudinal surveys in which all wood accumulations are mapped with GPS during boat-based surveys. Repeat mapping of large wood accumulations can be overlain on active channel mapping to track changes in large wood over time, identify reaches that are most likely to receive and accumulate wood jams, and relate wood abundance with conditions that promote large wood - for example, channel conditions, riparian forest condition, flow regimes, bank erodibility, channel dynamism.

- Analyzing migration rates, avulsions, bar building, and bank erosion by comparing channel maps from multiple time periods to link channel changes with specific flood events or flow regimes. To compare mapped features accurately from different time periods, the features will need to be normalized to account for differences in streamflow at the time of photograph (or lidar) acquisition (Wallick and others, $2010 ; 2011$ ). If mapping is carried out every $1-3$ years, the resulting datasets of mapped features can be used to assess geomorphic responses to the overall flow regime bracketed by the mapping (for example, Jones and others, 2016). To evaluate geomorphic responses to a large flood or other flow event likely to trigger major channel change, the mapping datasets must closely bracket the flow event of interest (for example, analyses of channel change from 1964 flood event by Wallick and others, 2010, 2011).

- Analyzing bank stability and bank erosion with repeat measurements of erosion pins. Erosion pin arrays can be installed on banks at repeat transects. Pin exposure would be measured following different environmental flow events to relate the degree of bank retreat or induced slumping to flow magnitude and duration (Hooke, 1980; Schenk and others, 2009).

\section{Approaches for Monitoring Channel Bed Elevation}

Gravel-bed rivers, such as those in the study area, can adjust their depth in response to changes in transport capacity and bed-material sediment supply, both of which are influenced by dams and their operations. When transport capacity exceeds bed-material supply, (which often occurs downstream of dams), an alluvial channel may incise, lowering its elevation relative to the flanking floodplain, which can have adverse effects on aquatic and riparian habitats (Kondolf, 1997). Previous studies have documented historical incision at USGS streamgages on the McKenzie and Santiam Rivers, and whereas the streamgage analyses indicate that incision at these streamgage sites has slowed or ceased in recent decades, the spatial extent and magnitude of historical and ongoing incision throughout the study area is unknown (Klingeman, 1979; Wallick and others, 2013). Conversely, when transport capacity is exceeded by bedmaterial supply, an alluvial channel may aggrade, or increase its bed elevation, which can reduce flow conveyance in the channel and increase flooding on adjacent land.

Given our current understanding of bed-material transport and channel morphology in the Willamette River Basin, we are not certain how environmental flows may affect current or future patterns of incision, nor can we anticipate how these adjustments might vary across the study area. Nevertheless, a possible objective for the Willamette SRP could be to reduce the potential for future incision along the main river channels of the study area to minimize associated reductions in aquatic and riparian habitats.

Assessing the locations and magnitudes of incision or aggradation will require repeat bathymetric surveys along each of the river corridors of the study area using a blend of field-based surveys and remotely sensed techniques. Avulsions and associated abrupt changes in bed elevation typically occur episodically in response to large floods, such as an avulsion at McKenzie River Oxbow, which triggered rapid downcutting through stable vegetated bars and subsequent filling of the former main channel between 2000 and 2005 (Jones and others, 2016). Changes in bed elevation also can occur gradually; for example, annual deposition of fine sediments in off-channel areas over multiple years can alter inundation patterns. To represent current changes in bed elevation owing to both episodic and gradual geomorphic processes, repeat bathymetric surveys could be carried out carried out every 5-10 years or following a large-magnitude flood event. Habitats that are actively changing could be re-surveyed more frequently, perhaps every 1-2 years; for example, routine surveys by the Oregon Department of Fish and Wildlife (ODFW) in offchannel areas of Fall Creek document seasonal aggradation and remobilization of fine sediment from sediment releases at Fall Creek Lake (Bangs and others, 2015, 2016). To provide geomorphic context for interpreting changes in bed elevation, repeat surveys could be planned to characterize existing reach morphology (table 1, appendix 1), and the resulting datasets could be coupled with other analyses of planform changes 
(described in section, “Approaches for Monitoring Channel Pattern, Planform, and Large Wood"). For example, repeat thalweg surveys of a particular reach may indicate areas of channel deepening, (potentially signifying incision), but repeat planform mapping of the same reach might indicate that the areas with deepening likely were newly formed scour pools at the apex of meander bends in an actively migrating reach. In this example, deepening was local, associated with typical meander migration processes and not accompanied by other signs of incision (such as channel narrowing or losses in gravel bars). A pragmatic approach for evaluating changes in channel bathymetry includes the following tasks (table 2):

\section{- Conducting boat-based surveys along each river,} supplemented with cross-section surveys at floodplain transects. These surveys could be obtained efficiently from a boat equipped with survey grade real-time kinematic global positioning systems (RTK GPS) to determine boat position and water elevation and a depth sounder or acoustic doppler current profile to obtain bathymetry. Depending on GPS signal, channel and flow conditions, and transect spacing, about $10-40 \mathrm{~km}$ of channel potentially can be surveyed in a single day. When compared with previously collected elevation datasets, repeat thalweg and cross-section surveys could indicate areas of incision or aggradation, as well as changes in the locations and depths of riffles, pools, and secondary channels. Because of the large size of SRP rivers (the alluvial reaches are 50-80 $\mathrm{m}$ in width) and the long length of the study reaches (tens of kilometers per river), boat-based surveys could focus on rapidly collecting thalweg data for entire reaches, with more detailed measurements only along floodplain transects or in sites where bed-level changes are suspected.

- Using water penetrating bathymetric lidar surveys, combined with conventional terrestrial lidar, to produce high-resolution elevation models of the channel and floodplain areas. Topobathymetric lidar surveys are already available for the Middle Fork Willamette River and Willamette River (Quantum Spatial, 2016; 2017) and provide seamless detailed topography of floodplain and shallow wetted areas. The depth of laser penetration depends on turbidity and suspended algae, and even in clear conditions is best suited for areas less than $2 \mathrm{~m}$ deep, so deeper pools would require boat-based surveys. The high-accuracy elevation data would provide the base for documenting detailed changes in channel and floodplain conditions and habitats - for example, measuring site-scale to reach-scale incision or aggradation when compared with other elevation data. Because of the expense, lidar surveys generally are coordinated with other local agencies and interests (to expand the study area and minimize the costs to individual organizations) and are best suited for reach-scale surveys at infrequent (5-10 year) intervals or following a major flood that triggers morphological changes along substantial segments of the river corridor.

- Conducting ground-based surveys in wadable areas such as riffles, secondary channels, or sections of the river with slow, shallow currents. See section, "Approaches for Monitoring Water-Surface Elevations and Inundation.” Ground-based surveys are useful for rapidly evaluating erosion and deposition in local, high-priority areas subject to more frequent changes (for example, measuring magnitude of deposition in side-channels where water depths and inundation patterns are affected by channel aggradation). Groundbased surveys could be focused on floodplain transects or important habitats within monitoring zones to supplement infrequent, reach-scale, lidar-based surveys.

- Evaluating patterns of incision and aggradation by comparing survey data from different time periods. The methods outlined here would provide baseline datasets from which to compare future changes. There also are multiple sources of recent and historical survey data from organizations that could be useful for assessing historical and recent trends (appendix 3). However, accurate assessment of incision or aggradation will require (1) consistent vertical datum between time periods, and (2) coupling repeat surveys with channel maps from different time periods to evaluate changes in bed elevation within the context of broader morphological changes.

\section{Approaches for Monitoring Bed-Material Texture}

The streambed substrate of alluvial rivers can change in response to variations in bed-material supply or transport capacity. When transport capacity exceeds the available supply of bed-material sediment, bed texture can coarsen, which can decrease the availability of spawning habitats (Kondolf and Wolman, 1993) and contribute to channel stability. Conversely, when the available supply of bedmaterial sediment exceeds transport capacity, bar and bed surfaces can adopt finer textures in response to sediment deposition. Although a local shift in particle size from coarse cobbles to smaller gravels may enhance spawning habitats, excessive deposition of fine sediments in gravel-bed areas potentially could have negative effects on aquatic habitats (Tappel and Bjornn, 1983; Everest and others, 1987; Roy and others, 2003). Streambed coarsening of gravel-bed reaches has been noted in the main-stem McKenzie River channel downstream of USACE dams (Minear, 1994) and in areas of the main-stem Willamette River (Klingeman, 1987). Some gravel-bed reaches immediately downstream of USACE dams have experienced decreases in substrate particle size due to 
the release of fine (clay to sand-sized) reservoir sediments associated with reservoir drawdowns. In settings with high transport capacity relative to sediment supply, channel fining can be temporary. For example, fine sediments deposited in main channel of South Fork McKenzie River during low flows were rapidly transported during subsequent high flows (Anderson, 2007). Where transport capacity is low relative to sediment supply, the deposition can be persistent. For example, in some low-velocity, off-channel areas of Fall Creek and Middle Fork Willamette River, fine sediments released from annual drawdowns at Fall Creek Reservoir have deposited and remained stable despite multiple high-flow events (Schenk and Bragg, 2014; Bangs and others, 2015;16; Keith and others, 2017). Evaluating current patterns of bedmaterial texture and monitoring future changes are critical for determining whether environmental flow releases could be implemented to minimize negative effects such as armoring in main channel habitats and excessive fine sediment aggradation in off-channel habitats.

In gravel-bed rivers such as those of the study area, bedmaterial textures can be highly variable between sites because of large-scale patterns such as selective transport and attrition, as well as local hydraulics. The methods for bed-material sampling are well established and have been used extensively to characterize streambed textures on a variety of other gravelbed rivers in western Oregon (Wallick and others, 2010; 2011; Jones and others, 2011; Jones, Keith, and others, 2012; Jones, O'Connor, and others, 2012a, 2012b; Podolak, 2012). An efficient yet comprehensive approach to evaluate current conditions and monitor long-term changes in bed texture is outlined in table 3 and could have the following elements:

\section{- Establishing a network of sites for periodically} sampling bed-material sediment sizes to track long term changes in bed texture. Ideally, 10-20 sites could be established along each reach. Sampling sites should be located on the apex of bars formed by recent deposition events, as indicated by the absence or minimal coverage of vegetation and selected based on bar size, accessibility, and condition (such as little to no vehicle disturbance). Sites could be classified according to channel type and sediment transport conditions to permit comparisons between geomorphically similar settings and sediment supply conditions. For example, gravel bars in sections with abundant bars and approximate balance between supply and transport capacity will have different textural and responses to environmental flows than armored bars in reaches where transport capacity far exceeds supply. Bed-material sampling sites could coincide with floodplain transects (fig. 11) and monitoring zones (figs. 3-6). Sites also could be selected in areas of different substrate types and where sediment transport processes are distinct from the main channel. For example, in alcoves or vegetated bar areas, the dominant process may be fine sediment deposition; thus, monitoring could track changes in grain size as the bed evolves from gravel substrate to finer sediment (silt, clay) to provide basis for evaluating associated changes in habitat quality or vegetation processes. At each site, the surface sizes of bed-material sediment should be sampled using a modified grid technique (Kondolf and others, 2003) similar to the approach used on other western Oregon gravel-bed rivers (Wallick and others, 2010; 2011; Jones and others, 2011; Jones, Keith, and others, 2012; Jones, O'Connor, and others, 2012a, 2012b), and a gravelometer (Federal Interagency Sediment Project US SAH-97 Gravelometer) that standardizes the measurement of sediment clasts greater than $2 \mathrm{~mm}$ in diameter. Grain-size distribution statistics, such as for median (D50), geometric mean, 16th (D16) and 84th (D84) percentiles, or cumulative frequency curves for multiple sites can be used to evaluate longitudinal trends and relations between channel morphology and bed texture.

- Sampling the subsurface material of gravel bars to evaluate bar armoring at select sites. Bulk samples could be collected from the same location at which surface material was measured by removing surface material and then collecting a minimum volume of sediment, which is dictated by sediment size (Bunte and Abt, 2001). Bulk samples can be submitted to a sediment laboratory to be dried and analyzed. Repeat sediment sampling could be carried out every 3-5 years or following a flow event that meets a threshold for a particular reach. Armoring ratios, the ratio of D50 of the surface to subsurface layers, can be computed to assess the relative balance between bed-material supply and transport capacity. The armoring ratio typically is close to 1 for rivers with a high sediment supply and approaches or exceeds 2 for supply-limited rivers (Bunte and Abt, 2001).

\section{- Mapping of areas of similar sediment size} (facies mapping) to supplement the particle-size measurements (Buffington and Montgomery, 1999). Sediment texture can vary substantially across individual bars because of variations in bar shape, elevation, vegetation, and other factors such as local hydraulics that influence patterns of erosion and deposition. Facies mapping relates sediment size to bar morphology; in turn, changes in sediment size can be related to variations in sediment supply or transport capacity (Podolak and Wilcock, 2013). Repeat facies mapping can be used to relate bar and floodplain changes to specific flow events (Moody and others, 1999) and evaluate responses to high-magnitude environmental flow releases. Ideal locations at which to focus this mapping effort would include permanent floodplain transects where other site-scale monitoring activities are located. 


\section{Approaches for Monitoring Floodplain Landforms}

Floodplain landforms are topographically higher than active channel landforms and encompass a variety of landforms such as secondary channels, sloughs, and natural levees that are mantled with fine sediment (sands, silts, and clays). Considering current patterns of streamflow regulation and bank stability, environmental flows are likely to result in more inundation and fine-sediment deposition along higherelevation parts of vegetated bars and low-lying floodplain surfaces such as swales than along topographically higher floodplain surfaces that may have been inundated during large historical floods but are seldom inundated by regulated floods (fig. 6). Environmental flows also could potentially influence the erosion of existing floodplain surfaces through lateral migration or avulsions, especially in areas with erodible banks and a high supply of bed-material sediment such as the laterally dynamic segments of the North Santiam River.

These monitoring activities allow the tracking the three stages of floodplain evolution: (1) creation of new floodplain surfaces, (2) evolution of existing floodplain surfaces, and (3) floodplain erosion. Because these processes occur episodically over periods of tens to thousands of years, the monitoring activities focus on collecting information at practical timescales. A pragmatic approach for monitoring floodplain responses to environment flows could incorporate the following activities:

- Mapping floodplain landforms from lidar to characterize existing conditions and provide a baseline for tracking future changes. This mapping would include delineating ridges, swales, natural levees, meander scars, and sloughs, and characterizing the topography of these features. The lidar-based landform maps could be developed in conjunction with the aerial photograph-based maps of the active channel (described in section, "Approaches for Monitoring Channel Pattern, Planform, and Large Wood") and would form a baseline inventory of features to quantitatively assess responses to the environmental flows. Mapping of floodplain landforms could be repeated every 10 years or following a large flood event. In the absence of a large flood that triggers substantial overbank scour or lateral erosion of floodplain surfaces, changes to floodplain surfaces typically entail gradual accretion of fine sediments; therefore, decadal-scale mapping should be sufficient to characterize changes to most floodplain features and could coincide with repeat mapping of active channel features.

\section{- Evaluating patterns of net erosion and deposition} by comparing lidar-based mapping from different time periods to assess overall trends and underlying processes. Geomorphic change detection software (such that developed by Wheaton and others, 2010) could expedite these analyses.

- Surveying floodplain topography and bathymetry along floodplain transects every 3-5 years (depending on flows). Repeat topographic surveys, focusing on areas within the 2-year flood inundation zone (as defined by River Design Group, Inc., 2012, 2013, 2017), would enable aggradation and scour to be quantified in habitat features such as floodplain sloughs and swales that are inundated more frequently and have greater rates of aggradation than higher-elevation floodplain surfaces. In conjunction with information on the flood magnitude, stage, and frequency of inundation, repeat surveys could be used to document aggradation associated with individual flood events.

- Measuring seasonal or event-based rates of floodplain deposition by installing deposition pads or plates along swales, vegetated bars, and other floodplain features to characterize rates and grainsize distributions of newly deposited sediment and organic matter content. Depending on site access, the pads can be visited between high-flow events or annually in summer months when sediment is collected. Sediment samples should be dried, sieved, and weighed (Steiger and others, 2003). Swales and vegetated bars are high priority for deposition measurements because they are likely to accumulate fine sediments and continued deposition may signify continued stability and limit inundation and access to off-channel habitats. Organic matter content could be assessed with loss on ignition tests from local laboratories. Areas to deploy deposition plates include monitoring zones or other areas with distinct swales and minimal disturbance from agriculture or other land uses that are within the 2-year flood inundation zone as defined by inundation maps (River Design Group, Inc., 2012, 2013, 2017).

- Measuring decadal-scale rates of fine-sediment deposition and floodplain creation since dam construction. This could be done by using historical aerial photographs to identify areas that have evolved from bare gravel bars to floodplain with mature vegetation (indicating lack of scour) in the decades since dam construction. Aerial photographs from different time periods can constrain the ages of these surfaces, and soil augering or trenching can constrain depth of fine sediment overlaying gravel substrate (Fitzpatrick and Knox, 2000; Fitzpatrick, 2005; Fitzpatrick and others, 2008). Because rates of floodplain development likely vary, depending on local hydraulics, flood history, and site conditions, these measurements could be repeated at multiple sites along each reach to target areas with varying ages and stages of vegetation succession and floodplain development. 
- Evaluating rates and processes of floodplain creation, floodplain evolution, and floodplain erosion. This could be done by comparing datasets from the floodplain mapping, event-based deposition rates, and decadal-scale deposition rates.

\section{Approaches for Monitoring Dewatering and Scour of Gravels in Spawning Reaches}

Spring Chinook salmon are listed as threatened under the ESA, and most spawning by wild fish is within the reaches immediately downstream of USACE dams where flow management affects the spatial distribution and survival of redds (figs. 7-10; National Marine Fisheries Service, 2008). Established flow targets for spawning and incubation (National Marine Fisheries Service, 2008, tables 2-10, p. 2-46) were adopted by the SRP (Gregory and others, 2007b; Risley, Bach, and Wallick, 2010; Bach and others, 2013). The monitoring approaches in this section address dewatering and scour, but water quality, such as temperature and dissolved gases, and fine sediment deposition on redds also can affect redd survival and could be incorporated in future monitoring. Although this report focuses on spring Chinook salmon, the monitoring approaches could be tailored to incorporate other threatened species, such as Upper Willamette River winter steelhead (Oncorhynchus mykiss) and native resident fish.

In the study area, spring Chinook salmon typically spawn in late August through October, and depending on water temperature and other local conditions, fry could emerge between November and May (National Marine Fisheries Service, 2008). Spawning periods coincide with lower fall flows and established streamflow targets, but because incubation continues into high-flow months, and the timing of fry emergence varies from year to year, redds could be potentially susceptible to scour depending on local hydraulic conditions. Evaluating the magnitude and extent of scour that may result from typical winter high-flow events could inform flow management and potentially benefit redd survival (Montgomery and others, 1996). Previous spawning assessments have used PHABSIM in the Middle Fork Willamette and McKenzie River Basins (River Design Group, Inc., 2014; River Design Group, Inc. and HDR, 2015) and cross-section evaluations in the Middle Fork Willamette and McKenzie River Basins (River Design Group, Inc., 2012, 2013) and Santiam River Basin (R2 Resource Consultants, Inc., 2014) that could support and inform reach- or transect scale monitoring.

The monitoring of redd dewatering and scour could be carried out in conjunction with spawning surveys and redd counts (Grimes and others, 1996) to link hydrogeomorphic responses from winter high flows (and streamflow targets) to spatial distribution of redds. The monitoring approach for spawning zones of spring Chinook salmon also can be applied to monitoring for winter steelhead and other native fish that use these reaches. These approaches also could be expanded to evaluate the influence of flow on rearing conditions in spring and summer following Chinook fry emergence (Schroeder and others, 2015). Reaches for monitoring spawning conditions in the study area are identified in figures 7-10. These reaches encompass highly used spawning areas downstream of USACE dams and were delineated based on input from fisheries biologists and previous studies (Greg Taylor, U.S. Army Corps of Engineers, oral commun., May 12, 2017; Mapes and others, 2017; Sharpe and others, 2017).

\section{Redd Dewatering}

Approaches for monitoring the timing, frequency, duration and magnitude of red dewatering could incorporate the following activities:

- Measuring water-surface elevation during spawning and incubation periods with pressure transducers. See section, "Approaches for Monitoring Water-Surface Elevations and Inundation.” Pressure transducers could be located within areas where redds are concentrated to record water elevations during spawning and incubation periods. When coupled with channel bathymetry (explained in the following bullet), continuous records of water depths over redds can be evaluated, and locations and time periods when redds were dewatered can be identified.

- Measuring channel bathymetry with boat-based sonar and RTK GPS. Channel bed and redd elevations within selected reaches could be mapped using techniques described in sections, "Approaches for Monitoring Water-Surface Elevations and Inundation" and "Approaches for Monitoring Channel Bed Elevation." Surveys could be carried out prior to or just after spawning season to document channel bed elevations. Likely locations of redds based on data from prior years (for example, Mapes and others, 2017; Sharpe and others, 2017) could be coupled with water-surface elevation data to assess likelihood of redd dewatering under different flow scenarios.

- Measuring channel elevation profiles with total station or level. See section, “Approaches for Monitoring Water-Surface Elevations and Inundation" for description of approaches for collecting wading or boat-based bathymetry, except surveys focused on spawning reaches could be targeted to include multiple transects in areas where redds are concentrated. Survey approaches may need to be tailored to account for poor RTK-GPS coverage (which is typical of the canyon reaches where some spawning zones are concentrated). 
- Photographing inundation at a range of flow conditions from fixed cameras on timers or during site visits. See section, "Approaches for Monitoring Water-Surface Elevations and Inundation." Cameras would likely be targeted at the streambed for lower flows. Photographs would provide qualitative basis for evaluating redd dewatering or could be used to evaluate water-surface elevations using "Structure from Motion" approach.

- Evaluating water conditions at redds using unmanned aerial system (UAS) photographic or bathymetric lidar surveys. UASs could be used to collect aerial photographs or lidar topography at the low flows during spawning season to determine if dewatering occurs.

\section{Redd Scour}

Approaches for identifying conditions when red scour may occur and the potential magnitude of channel bed erosion in spawning reaches could incorporate the following activities:

- Detecting bed-material movement in relation to flow using hydrophones (Marineau and others, 2015). Hydrophones could be deployed to record sound made by coarse sediment movement. Understanding the flow conditions when spawning substrate in a particular reach is mobilized and the relative magnitude of bed material transport for flows that exceed the mobilization threshold could inform high-flow management or be used to evaluate potential magnitude of redd scour in different years. Hydrophones could be deployed in spawning reaches throughout spawning periods or for a short period (a few days to a few weeks) during other high-flow environmental flow components.

- Measuring of scour (or aggradation) with scour chains (Lisle and Eads, 1991; Montgomery and others, 1996). An array of scour chains could be installed in spawning reaches during the non-spawning period. The chains could be installed at various points within the reach or along transects where redds may be subject to scour from environmental flow releases. Repeat measurements over the course of a year following implementation of different environmental flow components or high-flow events would inform the magnitude of scour (or aggradation) as well as the spatial distribution.
- Measuring of scour or gravel mobility with accelerometers (Gendaszek and others, 2013). An array of accelerometers could be installed in spawning reaches during the non-spawning period to measure the timing of scour and bed-material mobilization at various depths. The accelerometers could be installed at various points within the reach or along transects where redds may be subject to scour from environmental flow releases. The spatial distribution could be tailored if deployment is coupled with scour chain installation. The accelerometers could be programmed for a specified time interval over the period of interest to monitor streambed response to different environmental flow components.

- Measuring channel bathymetry with boat-based sonar and RTK GPS or total station. See this method in section, "Approaches for Monitoring Redd Dewatering."

- Measuring channel elevation profiles using total station, or level. See this method in section, "Approaches for Monitoring Redd Dewatering."

- Evaluating scouring of redds using UAS photographic or bathymetric lidar surveys. See this method in section, "Approaches for Monitoring Redd Dewatering."

- Tracking bed mobility by planting tracer gravels (Wilcock, 1997). Gravel coated with bright paint could be placed within the spawning reach of interest and coordinates could be recorded with GPS. Repeat site visits to relocate the tracer clasts and assess bed mobility would be event-based. Tracer clasts that have been mobilized and transported away from the planting site typically have a low recovery. Regardless of success of recovering tracer clasts, the fact that they are not in their original planted location could indicate that particular flows could transport spawning-size sediment. However, non-movement is not an indicator of no bed movement, as there could be partial transport of the channel bed (Wilcock and others, 2009).

- Evaluating scour and intrusion of sediments in spawning beds (Lisle and Eads, 1991; Anderson, 2007). Exact methods will depend on site conditions, but a variety of experimental methods can be used to evaluate scour of grain-size classes and fine sediment intrusion into spawning beds (Lisle and Eads, 1991; Anderson, 2007). 


\section{Monitoring Riparian Vegetation Responses to Environmental Flows}

Flow recommendations for streams in the study area were developed to promote multiple stages of floodplain forest succession with a goal of creating a diverse vegetation mosaic composed of varying age classes and seral stages of native riparian plant communities. To support this goal, flow targets focus on black cottonwood and Pacific willow (Salix lasiandra) because the life history of black cottonwood is tightly coupled with floodplain hydrology and this relation is well documented (Bradley and Smith, 1986; Cooper and others, 2003; Rood and others, 2005; Gregory and others, 2007a). The monitoring approaches described in this section are designed to evaluate the responses of different seral stages of cottonwood succession to environmental flows, with the assumption that environmental flows benefit cottonwood and other native species that compose these plant communities. These native species include many species of willow (Salix spp.), white alder, Oregon ash, bigleaf maple, Oregon white oak (Quercus garryana), hazel (Corylus cornuta var. californica), black hawthorn (Crataegus douglasii), and red alder (Alnus rubra).

The approaches in this monitoring framework assume that sexual reproduction of cottonwoods is an important mechanism to create genetically diverse stands of cottonwood, that existing stands of mature cottonwood provide ample seed sources, and that proximity to seed sources is not a factor limiting cottonwood recruitment. However, vegetative reproduction of cottonwoods (clonal saplings are generated from branch fragments) likely also is a major mechanism for stand development in the study area based on observations of abundant, vigorous clonal saplings (Jones and others, 2016) and previous studies (Gregory and others, 2007a). The assumption of unlimited seed supply is based on previous studies (Gregory and others, 2007a), anecdotal observations by the authors of abundant seed distributions on gravel bars throughout the study area and conversations with cottonwood experts (J. Freidman, U.S. Geological Survey, oral commun., May 8, 2014), but future research could determine if there are reaches of river corridors where seed supply is a limiting factor and also could determine the relative importance of vegetative and sexual reproduction of cottonwoods (appendix 3). Although not addressed specifically in these monitoring framework approaches, it also may be important to track non-native plant species such a reed canarygrass (Phalaris arundinacea L.) or Japanese knotweed (Fallopia japonica), which may out compete native flora for establishment and affect longer term succession.
Our current conceptual model of floodplain forest recruitment and succession in the Willamette Valley is described more fully in Gregory and others, (2007a) and Wallick and others (2013). To summarize, there are four key phases of vegetation recruitment and succession that correspond with distinct environmental flow components (fig.13):

1. During seed dispersal, black cottonwood seeds are spread by wind or water between May and mid-July (Dykaar and Wigington, 2000). Spring pulse flows that coincide with seed release can disperse seeds throughout the river corridor. Cottonwood seeds require bare and moist surfaces, such as gravel bars or recently deposited overbank sediment, for germination. The amount of time a seed remains viable is dependent on exposure to moisture. If seeds remain wet, they lose viability within 2-3 days; but if dry, they remain viable for longer periods. Flow conditions during this time are critical to successful germination. Additionally, because cottonwood seeds require bare, exposed surfaces for germination, winter high flows may be needed to for sediment erosion, transport and re-deposition that produces suitable locations for seed dispersal and establishment.

2. During stand initiation, shade-intolerant pioneer species such as black cottonwood germinates and grows rapidly on bare gravel bars. As spring flows recede, the roots of these young seedlings lengthen to access declining water tables. Recession rates that outpace root extension can cause seedling mortality. Gradually declining water levels that recede $0-2.5 \mathrm{~cm} /$ day are optimal for many species of cottonwood (Mahoney and Rood, 1998). Summer base flows also are important for young cottonwoods because mortality can result from both drought conditions and inundation.

3. Continued establishment and survival of young forest stands require suitable flow conditions for multiple years as the stand progresses through stem exclusion and early seral succession (Braatne and others, 2007). For example, seedlings that establish about $1-2 \mathrm{~m}$ above the zone of repetitive scour are better able to withstand erosion from winter high flows and proceed to later phases of succession than seedlings on lower bar surfaces (Polzin and Rood, 2006; Cline and McAllister, 2012).

4. The recycling of mature forest stands through floodplain erosion during floods creates bare patches that can be colonized by pioneer vegetation and liberates coarse sediment and wood that can be re-deposited in downstream habitats. Over the span of decades or centuries, floodplain recycling combined with vegetation succession creates a diverse floodplain forest mosaic of different-age classes. 


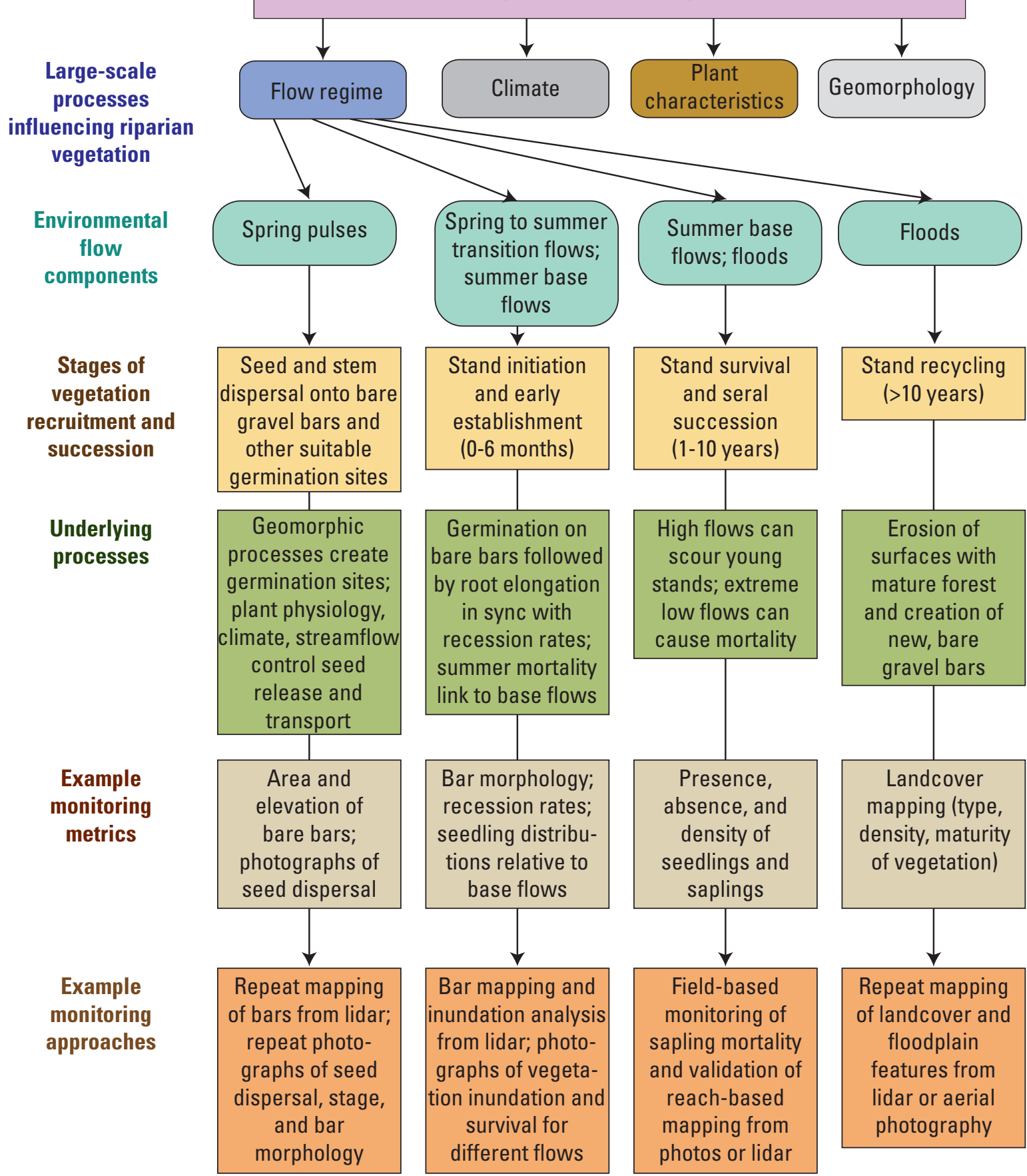

Figure 13. Conceptual model of vegetation recruitment, stand initiation, succession, and stand recycling, and approaches for monitoring those processes. 
A continuum of multiple floodplain seral stages and floodplain forest recruitment likely is limited by a lack of bare gravel bars that support the colonization and continued establishment of pioneer species, such as black cottonwood and willows (Gregory and others, 2007a; Cline and McAllister, 2012; Wallick and others, 2013). Channel stability limits floodplain erosion and the "recycling" of mature stands of floodplain forest communities whereby sediment and large wood enters the river channel, contributing to new gravel bars and other surfaces that may support successful establishment of black cottonwood. Even in stable to moderately stable reaches with successful cottonwood germination on bare gravel bars, these seedlings are subject to erosion by high flows. Studies on the Willamette River show that in some locations, young seedlings are established each spring but scoured during the following high-flow season because erosive flows are confined to a narrow corridor through stable channel reaches (Cline and McAllister, 2012). As a result, the river corridors throughout the Willamette study area are flanked by dense, mature forest stands that are more homogeneous and are more on an overall trajectory towards late-succession species (such as maples) than during historical periods (Gregory, Ashkenas, Haggerty, and others, 2002; Gregory and others, 2007a; Wallick and others, 2013). Streamflows during spring and summer potentially can limit stand establishment because spring recession rates can outpace root elongation and summer flows can inundate young seedlings. The relative importance of these factors and how they vary from year to year or between reaches is not known. Therefore, the monitoring approach outlined here would provide information critical for evaluating effectiveness of environmental flow strategies, refining flow-ecology relations, and addressing these knowledge gaps. Together, this process will ultimately support adaptive management of environmental flow targets.

The monitoring activities needed to assess vegetation responses to environmental flows are summarized in figure 13 and table 4, and are divided into two categories: (1) hydrogeomorphic activities used primarily to identify and track likely sites for plant establishment, and floodplain erosion and stand recycling promoting large-wood recruitment and new sources of gravel; and (2) vegetation monitoring activities to track all phases of vegetation recruitment and succession.. The vegetation monitoring tasks are further divided by scale. More detailed activities could occur at the site-scale along transects, primarily within laterally dynamic monitoring zones, whereas reach-scale monitoring can detect status and trends in overall floodplain forest conditions. Because vegetation recruitment and succession are gradual processes punctuated with episodic erosion that can recycle existing vegetation stands, evaluation of the overall success of the Willamette SRP on cottonwood recruitment and succession will require a multi-year approach.

\section{Approaches for Monitoring Hydrogeomorphic Conditions that Influence Vegetation Recruitment}

Because a lack of establishment sites likely is an important factor limiting vegetation recruitment throughout the study area, high-priority tasks for all study reaches include the following:

- Identifying unvegetated gravel bars that provide likely sites for seed germination and stand establishment. As described in section, "Approaches for Monitoring Channel Patterns, Planform and Large Wood", bare gravel bars are readily mapped from lidar or aerial photographs. Channel segments that are more laterally active would likely have a greater area of unvegetated gravel bars than straighter or single-thread segments along revetments or resistant geologies that limit migration.

- Assessing bar inundation for different flows to evaluate how environmental flows will influence seed dispersal and stand establishment in a given year. Inundation can be monitored using field-based methods described in section, "Approaches for Monitoring Water-Surface Elevations and Inundation”, such as surveying a transect and installing seasonal monuments, and then measuring distance from the monument to the water edge during subsequent site visits (Jones and others, 2016).

- Developing reach-scale maps of potentially successful zones for cottonwood establishment by coupling maps of gravel bars with inundation patterns. Previous studies have shown that cottonwood recruitment is most successful at elevations 30-200 cm greater than the summer base flow stage (Mahoney and Rood, 1998). Repeat mapping every 3-5 years could be used to track changes in the abundance of establishment sites.

- Developing streamflow models as a related tool to understand inundation of gravels at variable flows along large reaches. See section, "Approaches for Monitoring Water-Surface Elevations and Inundation." Although not a monitoring activity, development of one-dimensional and two-dimensional streamflow models can be used to evaluate reach-wide inundation patterns at different flows and incremental changes in water-surface elevation relative to discharge to inform monitoring activities. Inundation patterns at gravel bars and other recruitment sites can vary greatly owing to variation in topography and hydraulics, making it challenging to apply observations from one site to other locations. A detailed reach-scale model would 


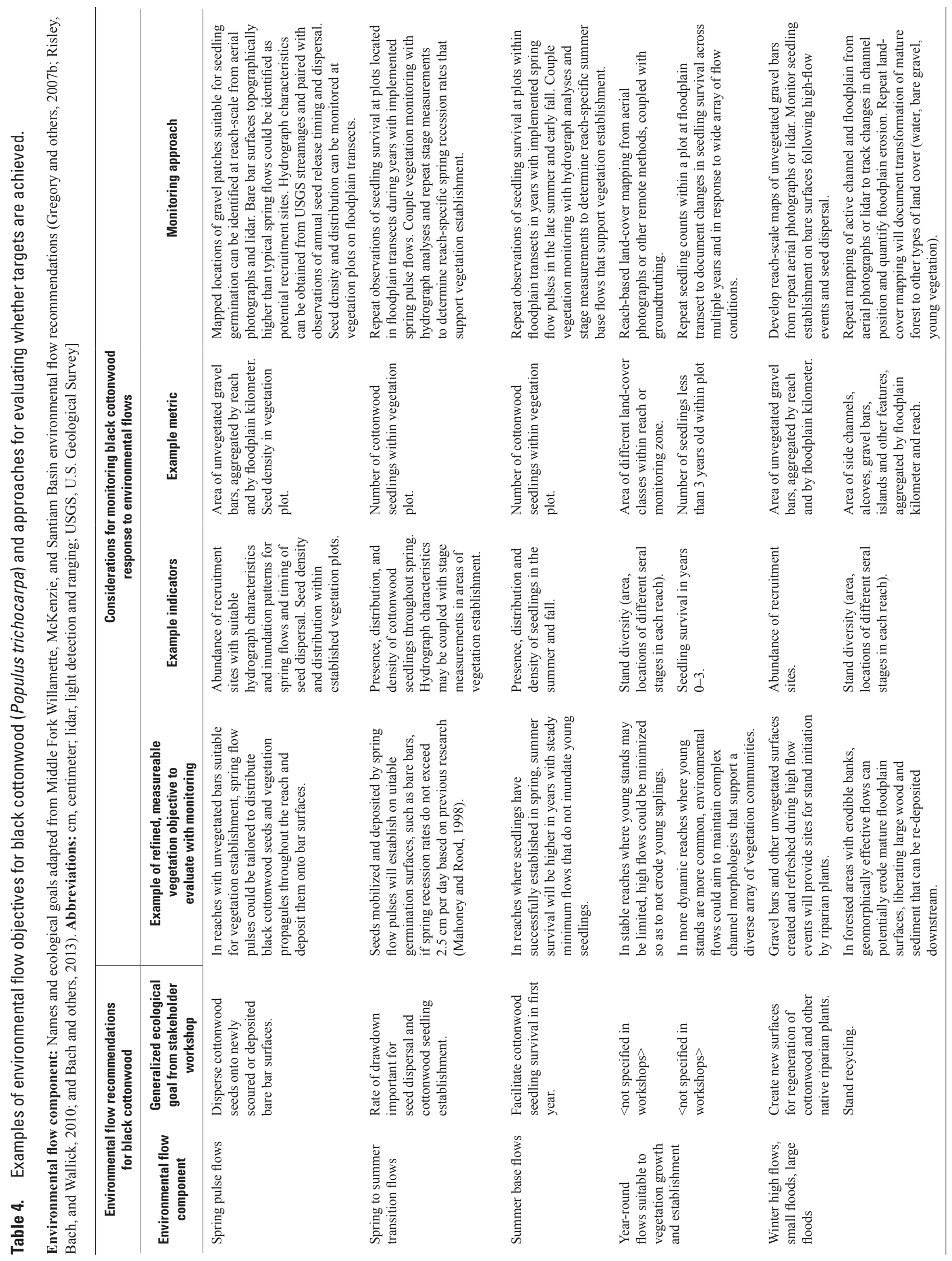


provide relations between discharge and bar inundation for recruitment sites, which could be paired with field-based monitoring to verify and refine the flowinundation relations. Model-generated inundation maps also can be used to evaluate seed dispersal for different flows, determine which flows may inundate young seedlings, and establish water-surface elevation maps to inform recession rate calculations. The effectiveness of environmental flow to support seed dispersal and stand establishment could be evaluated using information collected in the following tasks:

- Assessing the timing and magnitude of spring pulse flow hydrographs relative to seed release by comparing streamflow hydrographs from streamgages with observed patterns of seed release in each reach. A goal for this analysis is to determine whether flows suitable for seed dispersal are occurring within the window of seed viability.

- Comparing maps of seedling distribution (described in section, "Reach-Based Mapping to Track Vegetation Recruitment and Succession") with inundation maps to determine the range of spring flow levels that would support stand initiation. Once a range of flows that would could support germination are identified, these flows could be verified through site-based observations at vegetation plots established on floodplain transects.

\section{Approaches for Monitoring Stand Recruitment and Succession}

Vegetation monitoring is divided into two categories: (1) reach-based mapping to provide broader context for evaluating the overall status and trends of floodplain vegetation in response to environmental flows, and (2) site-based monitoring along transects and within zones to yield detailed information on stand establishment and succession.

\section{Reach-Based Mapping to Track Vegetation Recruitment and Succession}

A comprehensive approach for evaluating changes in floodplain vegetation would entail detailed landcover mapping for entire reaches of the study area. The mapping would delineate different seral stages of floodplain forest succession and provide baseline datasets for evaluating future changes that may result from environmental flows or other influences. Mapping could include the following tasks:
- Mapping floodplain vegetation using aerial photographs, lidar, and ground-truthing to map different seral stages or heights of floodplain forest vegetation. This task is like the 2010 floodplain forest mapping effort for the Willamette River (Institute for a Sustainable Environment, 2017) and underway for Willamette River tributaries (D. Hulse, University of Oregon Department of Landscape Architecture, written commun., July 17, 2017). Metrics could include the area of floodplain forest within different inundation zones and habitat features within specified distance of the river channel. For example, SLICES provides the area of floodplain forest inundated by 2-year recurrence interval flow event and percentage of bank that is forested (Institute for a Sustainable Landscape, 2017).

- Conducting repeat landcover mapping for the floodplain every 10 years or following a largeflow event. Analyses of landcover changes would depict areas where existing stands were reset by high flows and where young stands are being established. In conjunction with repeat mapping of channel and floodplain morphology (as described in Approaches for Monitoring Channel Pattern, Planform, and Large Wood), repeat landcover mapping would improve the understanding of the relation between flood magnitude, geomorphic processes, and vegetation succession.

- Collecting and analyzing repeat lidar surveys to address changes in stand growth, succession, and diversity. Lidar data have been shown to provide accurate measurements of forest parameters including canopy height, stem density, and biomass (Means and others, 2000; Kim and others, 2003). Repeat lidar surveys every 5-10 years would provide quantitative measurements of floodplain forest canopy growth and succession. Lidar data can be paired with multispectral imagery to map vegetation species distribution and succession (Hakkenberg and others, 2018). Additionally, these monitoring approaches could identify areas of stand recruitment or floodplain recycling.

\section{Site-Scale Monitoring Tasks}

Site-scale monitoring tasks could use vegetation plots to support statistically robust, repeatable observations over time. Vegetation plots should be located along established floodplain transects where hydrologic and geomorphic information also is collected (figs. 13-14). The approach will depend on site characteristics and monitoring objectives. A sampling scheme generally should be along a transect containing geomorphic landforms, such as gravel bars, young floodplain, and mature 
floodplain, and different stages of vegetation recruitment and succession (Gurnell and others, 2012; Jones and others, 2016). Along this transect, monitoring plots can be established to examine vegetation changes over time. Plot size will vary with the vegetation being targeted by the monitoring. For instance, smaller plots could be used to measure seedling density, whereas larger plots may be needed to evaluate stand diversity in mature forests. Monitoring changes at the site level can be very resource-intensive. The following tasks may be considered if resources allow for field-based monitoring at this scale:

- Monitoring seed distribution and germination using repeat ground-based photographs or plot-based vegetation surveys. Photographs would provide qualitative information for comparisons over time, whereas plot-based surveys could include species identification and provide a basis for quantifying seedling mortality and cover of native and invasive plants (fig. 14). Repeat photographs at monitoring plots distributed across floodplain transects could be taken before, during, and after seed release to document the timing and spatial distribution of seed dispersal across the active channel and floodplain. Photographs and surveys to document germination could occur 1 week to 1 month after seed release and spring pulse flows to ensure sufficient time for seed germination and to document potential effects of spring transition flows. Black cottonwood plants should be classified as seedlings or root sprouts. Photograph monitoring points could first be established in laterally dynamic monitoring zones where geomorphic conditions are suitable for seed dispersal and germination. If resources allow, photograph monitoring points may be established at additional sites, such as along permanent monitoring transects or stable monitoring zones along each reach.

- Measuring seedling mortality periodically throughout the spring to evaluate seedling response to spring recession flows and establish a range of variability. Small areas along transects could be identified as suitable for seedling establishment within each reach. Initial focus could be along transects within laterally dynamic monitoring zones. If resources allow, additional monitoring could be completed along transects in stable monitoring zones. Seedling distribution and survival numbers may be coupled with air temperature, precipitation, bar elevation, substrate, water level, density of habitat-altering invasive species, and browsing density to account for other variables influencing seedling mortality (fig. 14; Jones and others, 2016).
- Measuring seedling growth and mortality in response to summer base flows, very low flows, and inundation that may result from flow augmentation. Approaches to monitoring would be like evaluation of spring recession flows, whereby seedling growth and mortality are assessed at vegetation plots (Jones and others, 2016).

If preliminary monitoring indicates that factors such as seed dispersal, spring flow recession rates, or summer base flows limit vegetation recruitment on a particular reach, the following tasks could aid in tailoring spring and summer environmental flow releases:

- Documenting the timing of annual seed release and developing a database to evaluate annual variability and long-term trends to tailor spring flows to the appropriate timeframe. Document temporal variability in timing seed release that may relate to weather patterns, climatic trends, or other factors, and that may vary between the SRP river basins (perhaps as function of latitude) or along each river corridor (due to elevation). Collect data to inform basin-specific spring flow releases that could involve qualitative observations at transects, perhaps documented with repeat photographs showing timing of seed dispersal.

- Evaluating relations between seed dispersal, streamflows, and inundation patterns to assess patterns of seedling distribution for different flows. Monitoring activities could include repeat photographs or surveys to document patterns of seed dispersal, which could be coupled with the inundation monitoring and streamflow analyses as described in section, "Approaches for Monitoring Water-Surface Elevations and Inundation".

- Assessing seedling mortality in response to spring transition flows. It may be challenging to establish linkages between streamflow recession rates and conditions experienced by seedlings because water table elevations will vary spatially and temporally due to site conditions, local hydrology, and other factors. Therefore, monitoring of seedling response to recession rates could focus on low elevation gravel bars where moisture conditions in the seedling root zone are likely to be tightly coupled with streamflow. The rate of water surface decline (as measured in adjacent channel using methods described in section, "Approaches for Monitoring Water-Surface Elevations and Inundation" could compared with seedling responses and literature-based guidelines to determine whether guidelines developed for other regions are applicable to the study area. 
A. Topographic survey of floodplain transect at the Oxbow site, McKenzie River with locations of landforms and vegetation plots

Figure shows part of floodplain transect spanning large gravel bar that extends between main channel and alcove. Bed-material textures are based on median grain size (d50) as determined from Wohlman pebble counts.

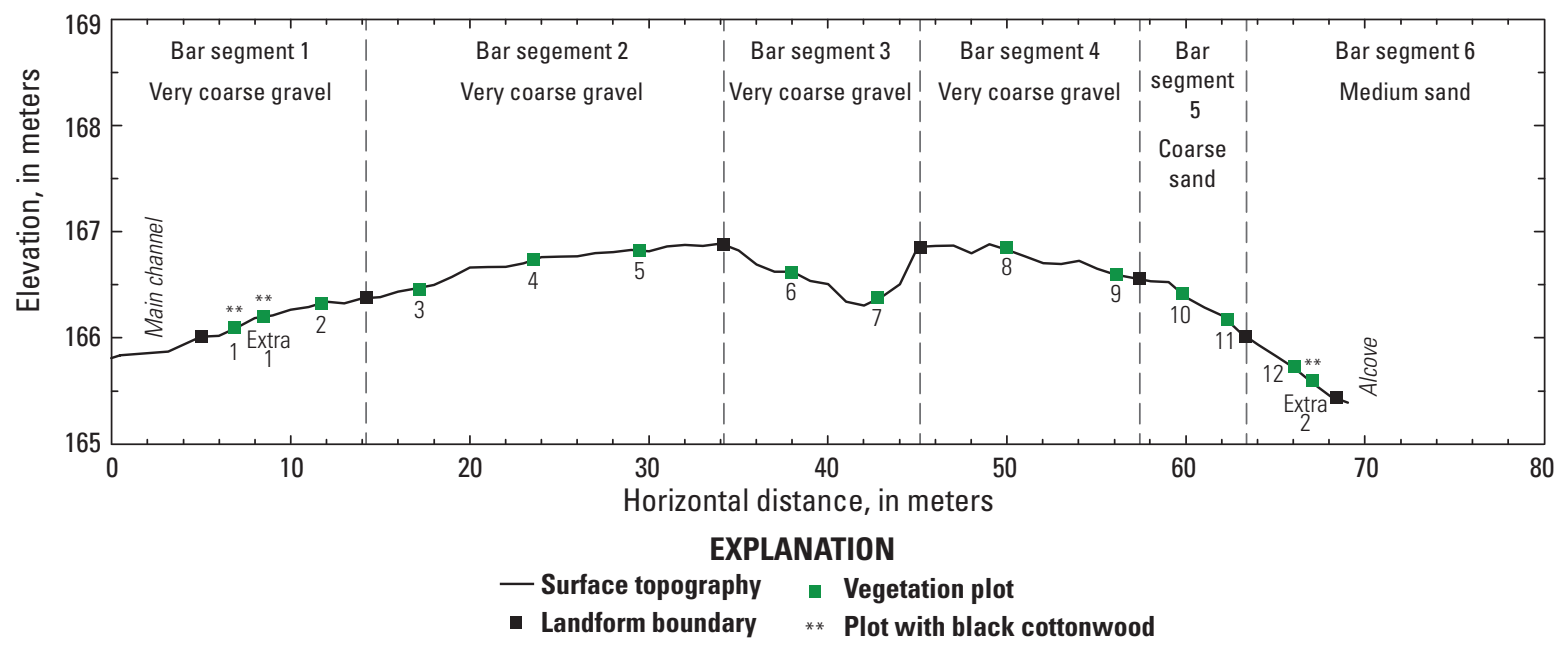

B. Repeat photographs of vegetation plot at 0 xbow site, McKenzie River

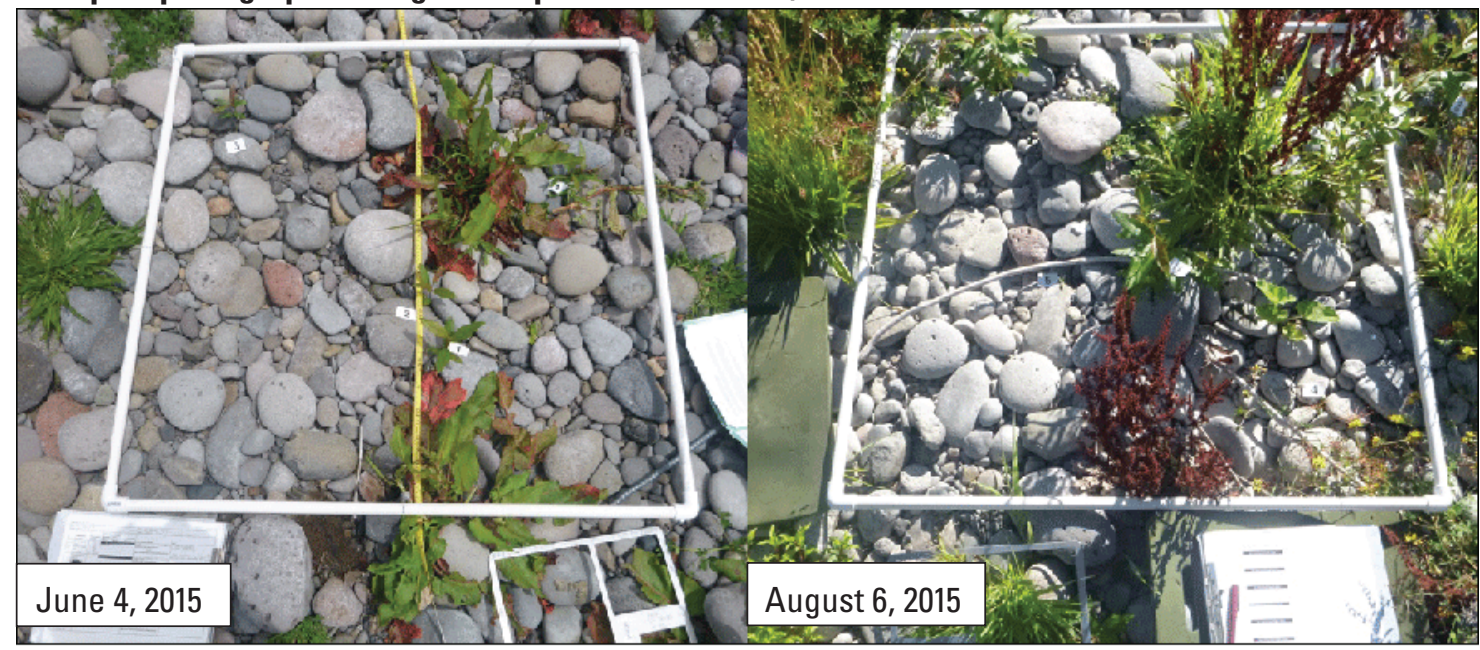

C. Repeat photographs along floodplain transect at the Confluence site, Middle Fork Willamette River

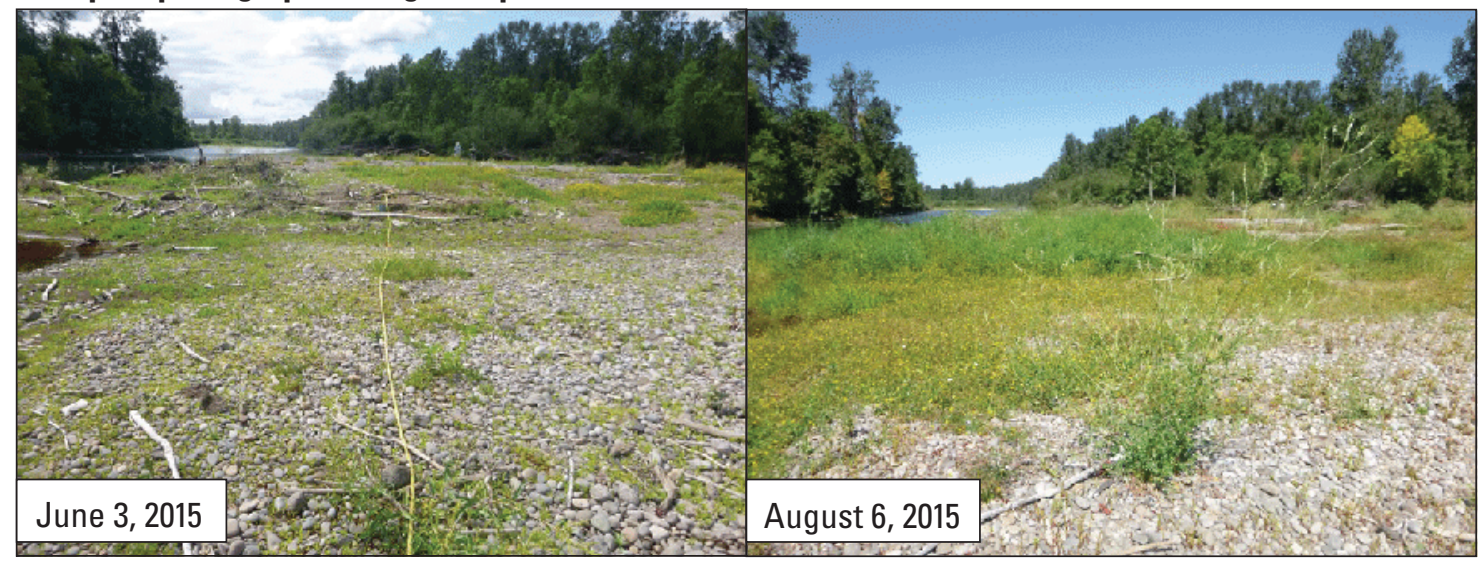

Figure 14. Monitoring approaches to evaluate black cottonwood establishment at Middle Fork Willamette, McKenzie, and Santiam River Basins, Oregon, summer 2015 (Jones and others, 2016). (A) Topographic survey of floodplain transect where repeat measurements of floodplain vegetation and water levels were made during summer of 2015; $(B)$ repeat plot-based photographs to document seedling germination, growth and mortality; and $(C)$ repeat photographs along a floodplain transect to document changes in vegetation growth across gravel bar. 
- Measuring seedling growth and mortality in response to dewatering during very low summer base flows and inundation that may result from flow augmentation. In conjunction with hydrograph analyses to establish criteria for defining different types of low flow conditions, monitoring observations could be tailored to coincide with key periods where dewatering or inundation of established seedlings may trigger mortality.

- Establishing monitoring plots along transects within each reach that encompass a range of seral stages. These plots could be a subset of the sites used to track vegetation recruitment.

- Monitoring phases of stem exclusion and early seral succession over 5-20 years. A longer-term monitoring effort could utilize monitoring plots for repeat observations of size classes, age classes, vegetation types and densities could be evaluated over time to assess stem exclusion and early seral succession.

\section{Conclusions}

This report summarizes approaches for monitoring hydrogeomorphic and vegetation responses to adaptively managed environmental flow releases recommended in the Willamette Sustainable Rivers Project (SRP). Although this monitoring program is intended to provide a basis for tracking progress towards objectives in the Willamette SRP, the monitoring approaches outlined here can apply to a wide range of other floodplain-management issues including flow management to support critical habitats for Endangered Species Act-listed species, effectiveness monitoring to evaluate river restoration activities, or assessment of floodplain hazards such as channel migration or flood inundation.

High-priority monitoring activities and associated analyses of monitoring data will generate baseline datasets describing floodplain conditions and relations between streamflow and the hydrogeomorphic and vegetation processes that create floodplain habitats. Key monitoring activities are summarized in table 5 and include the following:

- Hydrograph analyses to characterize seasonally varying flow conditions throughout the year document the timing, magnitude, and duration of the environmental flow components for each SRP basin to determine which flow targets were achieved;

- Measurements of water-surface elevations and inundation extent to characterize longitudinal and lateral patterns of habitat availability across seasonally varying flow conditions;
- Repeat mapping of channel and floodplain features from lidar and aerial photographs to characterize existing conditions and evaluate patterns of channel change;

- Repeat surveys of channel bathymetry to track the incision and aggradation that could affect sensitive habitats;

- Repeat mapping of unvegetated gravel bars from aerial photographs to identify potential recruitment sites for black cottonwood (Populus trichocarpa) and other floodplain plant species and to evaluate how these zones respond to streamflow;

- Plot-based observations of seedling survival and early establishment to evaluate black cottonwood responses to seasonal flows and other factors; and

- Evaluation of stand diversity from field observations and repeat landcover mapping to characterize current and future forest diversity and assess streamflow-forest interactions.

The alluvial, gravel-bed segments of Middle Fork Willamette, McKenzie, North Santiam, South Santiam, and main-stem Santiam Rivers have many of the building blocks to support healthy floodplain and aquatic ecosystems despite historical and ongoing alterations. Although general reach conditions are qualitatively described in this report, baseline datasets are lacking to more accurately describe the spatial distribution of channel features and vegetation conditions along each reach and associated patterns of inundation that result from different flows. This lack of baseline datasets and ongoing monitoring to measure changes over time make it challenging for SRP stakeholders to set realistic, reach-specific ecological goals for the SRP to assess the effectiveness of existing flow targets and to adaptively manage and refine flow targets over time. However, the monitoring framework described in this report could yield the datasets and insights to flow-ecology relations to support the adaptively managed environmental flow program of the SRP.

Although the Willamette SRP aims to sustain these diverse floodplain ecosystems through an environmental flow program, other constraints may cause some sections of the study area to undergo continuing habitat declines in coming decades. Some of these other constraints include local bank stabilization, trapping of gravel by upstream dams, and reductions in large wood. These constraints should be taken into consideration in setting realistic, reach-specific ecological goals for environmental flows and assessing the results of the program. To aid in this process, this monitoring framework describes reach-scale conditions and provides considerations to inform reach-specific hydrogeomorphic and vegetation monitoring activities. Additional information included in this report to inform a future environmental flow monitoring program includes: 


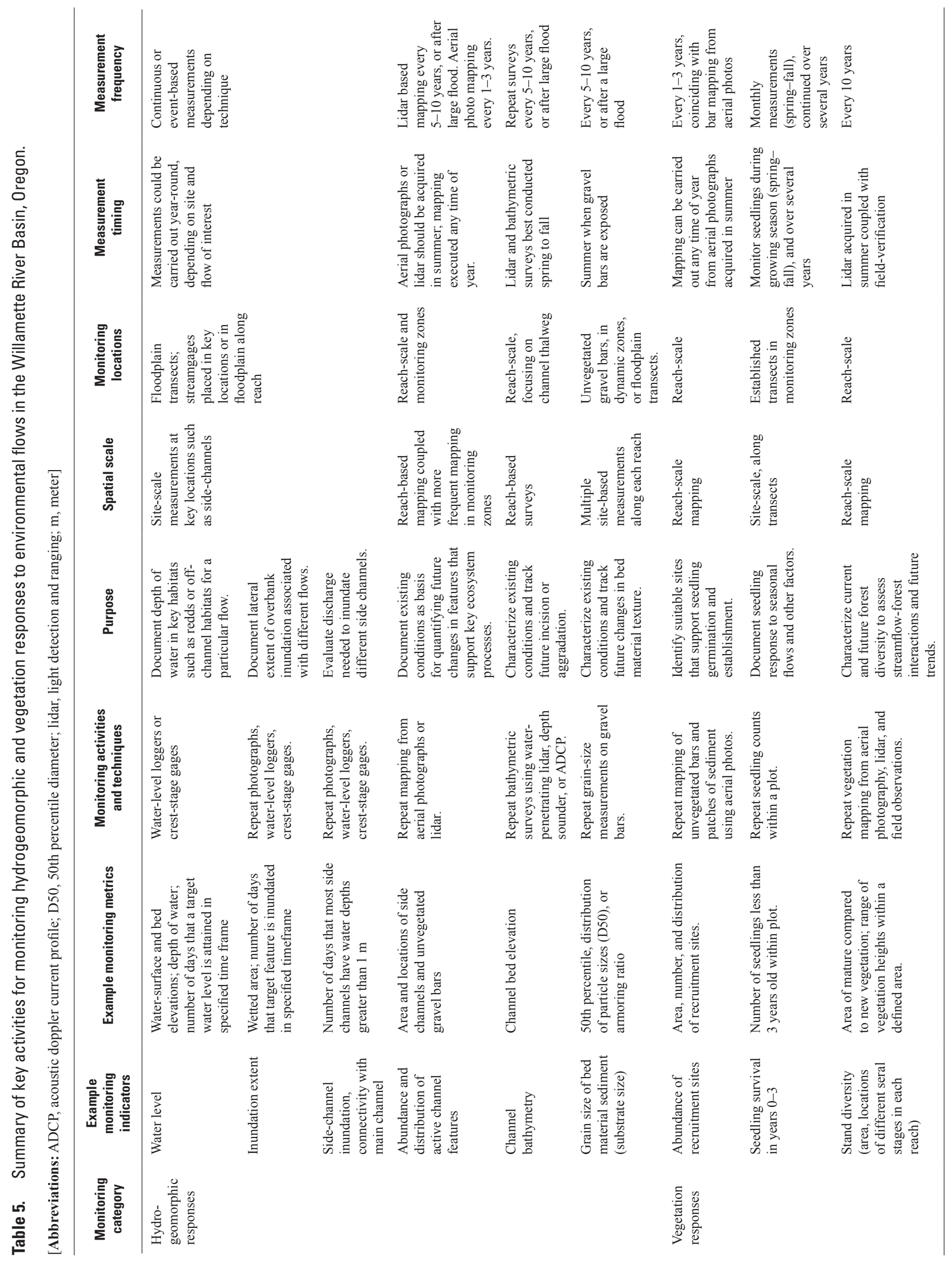


- A description of past and ongoing hydrogeomorphic, vegetation, and biological research that could be leveraged to streamline future SRP monitoring efforts;

- A description of hydrograph analyses that would be useful for validating environmental flow implementation and to provide a basis for comparing hydrogeomorphic and vegetation responses with distinct environmental flow components; and

- A summary of outstanding research questions that, when addressed, will provide important data and information needed to refine the flow recommendations.

With refined ecological goals and associated hydrogeomorphic and vegetation objectives in place, a comprehensive monitoring program, developed with the approaches outlined in this report, could be used to inform an adaptively managed environmental flow program. Data from this monitoring program also could be used to prioritize habitat restoration efforts and evaluate status and trends of important aspects of the floodplain system, such as inundation patterns, channel morphology, and floodplain forests, which together support a complex mosaic of aquatic and riparian habitats.

\section{Acknowledgments}

Chris Budai and Keith Duffy (U.S. Army Corps of Engineers [USACE], Portland District) provided project oversight and administration. The vegetation monitoring approaches and scientific background presented in this report were initially developed by Emilie Blevins (Xerces Society). This study also benefited from discussions with many individuals and organizations working in habitat restoration, research, and monitoring in the Willamette Valley, including Stan Gregory (Professor emeritus, Oregon State University, Department of Fisheries and Wildlife); David Hulse (University of Oregon, Department of Landscape Architecture); Greg Taylor, Rich Piaskowski, Jacob Macdonald, Mary-Karen Scullion, and Jim Burton (USACE, Portland District); Wendy Hudson (retired) and Ken Fetcho (Oregon Watershed Enhancement Board); Anne Mullan, (National Oceanic and Atmospheric Administration, Fisheries); Karl Morgenstern (Eugene Water and Electric Board); Joe Moll and Jodie Lemmer (McKenzie River Trust); Kathleen Guillozet (Bonneville Environmental Foundation); Jason Nuckols and Zach Freed (The Nature Conservancy [TNC]); Troy Brandt and Peter Gruendike (River Design Group, Inc.); Lawrence Schwabe (Confederated Tribes of the Grande Ronde); Rebecca McCoun (North Santiam Watershed Council); Eric Anderson (South Santiam Watershed Council); Robert Naiman (Professor Emeritus, University of
Washington, School of Aquatic and Fisheries Sciences); and Tom Friesen, Kirk Schroeder, Brian Bangs, Brian Cannon, and Luke Whitman, (Oregon Department of Fisheries and Wildlife); Jim Peterson (USGS) and Tyrell Deweber (Oregon State University); Kate Meyer, Johan Hogervorst and Matt Helstab (U.S. Forest Service); and Sarah Dyrdrahl and Audrey Squires (Middle Fork Watershed Council). Jonathan Freidman (U.S. Geological Survey [USGS] Fort Collins Science Center) shared insights on approaches for evaluating relations between streamflows and cottonwood. Faith Fitzpatrick (USGS Wisconsin Water Science Center) provided a helpful initial review of the Willamette SRP research and monitoring program. Allison Aldous (TNC) provided an instructive review of the monitoring framework and suggestions that greatly improved this manuscript. James White and Brandon Overstreet (USGS Oregon Water Science Center) provided helpful reviews and input on technical approaches described in the manuscript.

\section{References Cited}

Acreman, M., and Dunbar, M.J., 2004, Defining environmental flow requirements-A review: Hydrology and Earth System Sciences, v. 8, no. 5, p. 861-876.

Anderson, C.W., 2007, Influence of Cougar Reservoir drawdown on sediment and DDT transport and deposition in the McKenzie River Basin, Oregon, 2002-04: U.S. Geological Survey Scientific Investigations Report 20075164, 42 p., accessed June 26, 2017, at https://pubs.usgs. gov/sir/2007/5164/.

Anderson, S.W., Keith, M.K., Magirl, C.S., Wallick, J.R., Mastin, M.C., and Foreman, J.R., 2017, Geomorphic response of the North Fork Stillaguamish River to the State Route 530 landslide near Oso, Washington: U.S. Geological Survey Scientific Investigations Report 2017-5055, 85 p., https://doi.org/10.3133/sir20175055.

Andrews, E.D., 1983, Entrainment of gravel from naturally sorted riverbed material: Bulletin of the Geological Society of America, v. 94, p. 1225-1231.

Andrews, E.D., 1984, Bed-material entrainment and hydraulic geometry of gravel-bed rivers in Colorado: Bulletin of the Geological Society of America, v. 95, p. 371-378.

Andrews, E.D., and Nankervis, J.M., 1995, Effective discharge and the design of channel maintenance flows for gravelbed rivers, in Costa, J.E., Miller, A.J., Potter, K.W., and Wilcock, P.R., eds., Natural and anthropogenic influences in fluvial geomorphology: American Geophysical Union, Geophysical Monograph 89, p. 151-164. 
Bach, L.B., Nuckols, J., and Blevins E., 2013, Summary report-Environmental flows workshop for the Santiam River Basin, Oregon: The Nature Conservancy, 25 p., accessed June 26, 2017, at https://www. conservationgateway.org/ConservationByGeography/ NorthAmerica/UnitedStates/oregon/freshwater/Documents/ Santiam\%20River\%20Workshop\%20Report.pdf.

Bangs, B.L., Neal, W.T., and Clements, S., 2016, 2015 Oregon chub investigations progress report: Annual Progress Report by Oregon Department of Fish and Wildlife, 88 p., accessed September 12, 2018, at: https://odfwnfi.forestry.oregonstate. edu/sites/odfwnfi/files/page_files/Bangs\%20et\%20al.\%20 2016.pdf

Bangs, B.L, Scheerer, P.D. and Clements, S., 2015, Effects of US Army Corps of Engineers Willamette Projects operations on Oregon chub and other floodplain fishes (2009-2012): Oregon Department of Fish and WildlifeProgress Reports.

Benner, P.A., and Sedell, J.R., 1997, Upper Willamette River landscape-A historic perspective, in Laenen, Antonious, and Dunnette, D.A., eds., River quality-Dynamics and restoration: Salem, Massachusetts, CRC Press, Inc., p. $23-47$.

Braatne, J.H., Jamieson, R., Gill, K.M., and Rood, S.B., 2007, Instream flows and the decline of riparian cottonwoods along the Yakima River, Washington, USA: River Research and Applications, v. 23, p. 247-267.

Bradley, C.E., and Smith, D.G., 1986, Plains cottonwood recruitment and survival on a prairie meandering river floodplain, Milk River, southern Alberta and northern Montana: Canadian Journal of Botany, v. 64, p. 1433-1442.

Brierley, G.J., and Fryirs, K.A., 2005, Geomorphology and river management-Applications of the river styles framework: Oxford, United Kingdom, Blackwell Publications, $398 \mathrm{p}$.

Buffington, J.M., and Montgomery, D.R., 1999, Effects of sediment supply on surface textures of gravel-bed rivers: Water Resources Research, v. 35, no. 11, p. 3523-3530, https://doi.org/10.1029/1999WR900232.

Bunte, K., and Abt, S.R., 2001, Sampling surface and subsurface particle-size distributions in wadable gravel and cobble-bed streams for analyses in sediment transport, hydraulics, and stream-bed monitoring: U.S. Forest Service, Rocky Mountain Research Station, General Technical Report RMRS-GTR-74, 428 p.
Church, M., 1983, Pattern of instability in a wandering gravel bed channel, in Collinson, J.D., and Lewis, J., eds., Modern and ancient fluvial systems: International Association of Sedimentologists Special Publication, v. 6, p. 169-180.

Church, M., 2002, Geomorphic thresholds in riverine landscapes: Freshwater Biology, v. 47, p. 541-557.

Cline, S.P., and McAllister, L.S., 2012, Plant succession after hydrologic disturbance-Inferences from contemporary vegetation on a chronosequence of bars, Willamette River, Oregon, USA: River Research and Applications, v. 28, p. 1519-1539.

Cooper, D.J., Anderson, D.C., and Chimner, R.A., 2003, Multiple pathways for woody plant establishment on floodplains at local to regional scales: Journal of Ecology, v. 91, no. 2, p. 182-196.

DeWeber, J.T., Peterson, J.T., Sharpe, C., Kent, M.L., Colvin, M.E., and Schreck, C.B., 2017, A hidden-process model for estimating prespawn mortality using carcass survey data: North American Journal of Fisheries Management, v. 37, p. 162-175.

Dietrich, W.E., and Smith, J.D., 1983, Influence of the point bar on flow through curved channels: Water Resources Research, v. 19, p. 1173-1192, https://doi.org/10.1029/ WR019i005p01173.

Dykaar, B.B., 2005, Status and trends of the Middle and Coast Forks Willamette River and their floodplain habitat using geomorphic indicators: Prepared by Ecohydrology West, Santa Cruz, California, for Willamette Partnership, Salem, Oregon, and U.S. Army Corps of Engineers, Portland, Oregon, $78 \mathrm{p}$.

Dykaar, B.B., 2008a, A catalogue of geomorphic change on the Middle and Coast Forks of the Willamette River using recent aerial orthophotography: Prepared by Ecohydrology West, Santa Cruz, California, for U.S. Army Corps of Engineers, Portland, Oregon, and Oregon Department of Fish and Wildlife, Salem, $37 \mathrm{p}$.

Dykaar, B.B., 2008b, A preliminary examination of some hydrogeomorphic factors limiting black cottonwood recruitment on the Middle and Coast Forks of the Willamette River: Prepared by Ecohydrology West, Santa Cruz, California, for U.S. Army Corps of Engineers, Portland, Oregon, and Oregon Department of Fish and Wildlife, Salem, 40 p.

Dykaar, B.B., and Wigington, P.J., Jr., 2000, Floodplain formation and cottonwood colonization patterns on the Willamette River, Oregon, USA: Environmental Management, v. 25, p. 87-104. 
Emmett, W.W., and Wolman, M.G., 2001, Effective discharge and gravel-bed rivers: Earth Surface Processes and Landforms, v. 26, p. 1369-1380.

Everest, F.H., Beschta, R.L., Scrivener, J.C., Koski, K.V., Sedell, J.R., and Cederholm, C.J., 1987, Fine sediment and salmonid production-A paradox, in Salo, E.O., and Cundy, T.W., eds., Streamside management—Forestry and fishery interactions: Seattle, University of Washington Institute of Forest Resources Contribution 57, p. 98-142.

Fitzpatrick, F.A., 2005, Trends in streamflow, sedimentation, and sediment chemistry for the Wolf River, Menominee Indian Reservation, Wisconsin, 1850-1999: U.S. Geological Survey Scientific Investigations Report 2005-5030, 55 p.

Fitzpatrick, F.A., and Knox, J.C., 2000, Spatial and temporal sensitivity of hydrogeomorphic response and recovery to deforestation, agriculture, and floods: Physical Geography, v. 21 , no. 2 , p. $89-108$.

Fitzpatrick, F.A., Peppler, M.C., Walker, J.F., Rose, W.J., Waschbusch, R.J., and Kennedy, J.L., 2008, Flood of June 2008 in southern Wisconsin: U.S. Geological Survey Scientific Investigations Report 2008-5235, 24 p.

Fonstad, M.A., Dietrich, J.T., Courville, B.C., Jensen, J.L., and Carbonneau, P.E., 2013, Topographic structure from motion-A new development in photogrammetric measurement: Earth Surface Processes and Landforms, v. 38, p. 421-430, https://doi.org/10.1002/esp.3366.

Freeman, L.A., Carpenter, M.C., Rosenberry, D.O., Rousseau, J.P., Unger, R., and McLean, J.S., 2004, Use of submersible pressure transducers in water-resources investigations: U.S. Geological Survey Techniques of Water-Resources Investigations, book 8, chap. A3 [variously paged].

Gendaszek, A., Czuba, C.R., Magirl, C.S., and Konrad, C.P., 2013, The timing of scour and fill in a gravel-bedded river measured with buried accelerometers: Journal of Hydrology, v. 495 , p. $186-196$.

Gilbert, G.K., and Murphy, E.C., 1914, The transportation of debris by running water: U.S. Geological Survey Professional Paper 86, $35 \mathrm{p}$.

Gregory, S., 2008, Historical channel modification and floodplain forest decline-Implications for conservation and restoration of a large floodplain river-Willamette River, Oregon, in Habersack, H., Piegay, H., and Rinaldi, M., eds., Gravel-bed rivers VI-From process understanding to river restoration: Oxford, United Kingdom, Elsevier B.V., p. 763-777.
Gregory, S., Ashkenas, L., Haggerty, P., Oetter, D., Wildman, K., Hulse, D., Branscomb, A., and Van Sickle, J., 2002, Riparian vegetation, in Hulse, D., Gregory, S., and Baker, J., eds., Willamette River Basin atlas: Corvallis, Oregon State University Press, p. 40, accessed August 23, 2013, at http:// oregonstate.edu/dept/pnw-erc/.

Gregory, S., Ashkenas, L., and Nygaard, C., 2007a, Summary report to assist development of ecosystem flow recommendations for the Middle Fork and Coast Fork of the Willamette River, Oregon: Corvallis, Oregon State University, Institute for Water and Watersheds, $237 \mathrm{p}$.

Gregory, S., Ashkenas, L., and Nygaard, C., 2007b, Summary report-Environmental flows workshop for the Middle Fork and Coast Fork of the Willamette River, Oregon: Corvallis, Oregon State University, Institute for Water and Watersheds, $34 \mathrm{p}$.

Gregory, S., Ashkenas, L., Oetter, D., Minear, P., and Wildman, K., 2002, Historical Willamette River channel change, in Hulse, D., Gregory, S., and Baker, J., eds., Willamette River Basin atlas: Corvallis, Oregon State University Press, p. 18-24, accessed August 23, 2013, at http://oregonstate.edu/dept/pnwerc/.

Gregory, S., and Hulse, D., 2002, Conceptual and spatial framework, in Hulse, D., Gregory, S., and Baker, J., eds., Willamette River Basin atlas: Corvallis, Oregon State University Press, p. 132-133, accessed June 26, 2017, at http://oregonstate.edu/dept/pnw-erc/.

Grimes, J.T., Lindsay, R.B., Kenaston, K.R., Homolka, K., and Schroeder, R.K., 1996, Annual progress report-Fish research project Oregon, Willamette spring Chinook salmon F-163-R-00, May 1996 through September 1996: Portland, Oregon Department of Fish and Wildlife, Project F-163-R-00, 41 p.

Gurnell, A.M., Bertoldi, W., and Corenblit, D., 2012, Changing river channels-The roles of hydrological processes, plants and pioneer fluvial landforms in humid temperate, mixed load, gravel bed rivers: Earth-Science Reviews, v. 111, p 129-141.

Hakkenberg, C.R., Zhu, K., Peet, R.K., and Song, C., 2018, Mapping multi $\square$ scale vascular plant richness in a forest landscape with integrated LiDAR and hyperspectral remote $\square$ sensing: Ecology, v. 99, p. 474-487.

Harr, R.D., 1981, Some characteristics and consequences of snowmelt during rainfall in western Oregon: Journal of Hydrology, v. 53, p. 277-304. 
Higgins, J.V., Konrad, C.P., Warner, A., and Hickey, J.T., 2011, A framework for monitoring, reporting and managing dam operations for environmental flows-Version 1.0: SRP Measures Working Group, The Nature Conservancy Conservation Gateway web page, accessed June 26, 2017, at https://www.conservationgateway.org/Files/Pages/ framework-monitoring-repo.aspx.

Hooke, J.M., 1980, Magnitude and distribution of rates of river bank erosion: Earth Surface Processes and Landforms, v. 5 , p. $143-157$.

Institute for a Sustainable Landscape, 2017, Floodplain forest ca. 2010 datasets and technical details: Eugene, University of Oregon Institute for a Sustainable Environment Lab web page, accessed July 24, 2017, at http://ise.uoregon.edu/ slices/data.html.

Jefferson, A., Grant, G., and Rose, T., 2006, Influence of volcanic history on groundwater patterns on the west slope of the Oregon High Cascades: Water Resources Research, v. 42, p. W12411, https://doi.org/10.1029/2005WR004812.

Jones, K.L., Keith, M.K, O’Connor, J.E., Mangano, J.F., and Wallick, J.R., 2012, Preliminary assessment of channel stability and bed-material transport in the Tillamook Bay tributaries and Nehalem River Basin, northwestern Oregon: U.S. Geological Survey Open-File Report 2012-1187, 120 p., accessed June 26, 2017, at https://pubs.usgs.gov/ of $/ 2012 / 1187 /$.

Jones, K.L., Mangano, J.F., Wallick, J.R., Bervid, H.D., Olson, M., Keith, M.K., and Bach, L., 2016, Summary of environmental flow monitoring for the Sustainable Rivers Project on the Middle Fork Willamette and McKenzie Rivers, western Oregon, 2014-15: U.S. Geological Survey Open-File Report 2016-1186, 91 p., accessed June 26, 2017, at https://dx.doi.org/10.3133/ofr20161186.

Jones, K.L., O’Connor, J.E., Keith, M.K., Mangano, J.F., and Wallick, J.R., 2012a, Preliminary assessment of channel stability and bed-material transport in the Coquille River Basin, southwestern Oregon: U.S. Geological Survey OpenFile Report 2012-1064, 84 p., accessed June 26, 2017, at https://pubs.usgs.gov/of/2012/1064/.

Jones, K.L., O’Connor, J.E., Keith, M.K., Mangano, J.F., and Wallick, J.R., 2012b, Preliminary assessment of channel stability and bed-material transport in the Rogue River Basin, southwestern Oregon: U.S. Geological Survey OpenFile Report 2011-1280, 96 p., accessed June 26, 2017, at https://pubs.usgs.gov/of/2011/1280/.
Jones, K.L., Wallick, J.R., O’Connor, J.E., Keith, M.K., Mangano, J.F., and Risley, J.C., 2011, Preliminary assessment of channel stability and bed-material transport along Hunter Creek, southwestern Oregon: U.S. Geological Survey Open-File Report 2011-1160, 41 p., accessed June 26, 2017, at https://pubs.usgs.gov/of/2011/1160/.

Keith, M., Wallick, J.R., Taylor, G., White, J., Mangano, J. F., Gordon, G., Schenk. L., and Bragg, H., 2017, Preliminary assessment of sediment transport and geomorphic responses to fine sediment delivery resulting from annual reservoir drawdowns at Fall Creek Lake: Abstract submitted to U.S. Army Corps of Engineers Willamette Fisheries Science Review, Corvallis, Oregon, February 7-9, 2017.

Kim, K., Treitz, P., Wulder, M., St-Onge, B., and Flood, M., 2003, LiDAR remote sensing of forest structure: Progress in Physical Geography, v. 27, no. 1, p. 88-106.

Klingeman, P.C., 1979, A resource survey of river energy and low-head hydro-electric power potential in Oregon: Oregon State University Water Resources Research Institute, no. 61, $71 \mathrm{p}$.

Klingeman, P.C., 1987, Geomorphic influences on sediment transport in the Willamette River, in Beschta, R.L., Blinn, T., Grant, G.E., Swanson, F.J., and Ice, G.G., eds., Erosion and the Pacific Rim, Proceedings of the Corvallis Symposium, August 1987: Corvallis, Oregon, U.S., Forest Service, Pacific Northwest Research Station, IAHS publication no. 165 , p. $365-374$.

Knighton, D., 1998, Fluvial forms and processes-A new perspective: New York, Arnold, 383 p.

Kondolf, G.M., 1997, Hungry water-Effects of dams and gravel mining on river channels: Environmental Management, v. 21, no. 4, p. 533-551.

Kondolf, G.M., Lisle, T.E., and Wolman G.M., 2003, Bed sediment measurement-Tools in fluvial geomorphology, chap. 13 of G.M. Kondolf, and Piégay, H., eds., Tools in fluvial geomorphology: Chichester, United Kingdom, John Wiley and Sons, Ltd., p. 347-389.

Kondolf, G.M., and Wolman, M.G., 1993, The sizes of salmonid spawning gravels: Water Resources Research, v. 29 , no. 7, p. 2275-2285.

Konrad, C.P., 2010, Monitoring and evaluation of environmental flow prescriptions for five demonstration sites of the Sustainable Rivers Project: U.S. Geological Survey Open-File Report 2010-1065, 22 p. 
Konrad, C.P., Warner, A., and Higgins J.V., 2011, Evaluating dam re-operation for freshwater conservation in the Sustainable Rivers Project: River Research and Applications, v. 28, no. 6, p. 777-792, accessed June 26, 2017, at https://onlinelibrary.wiley.com/doi/10.1002/ rra.1524/pdf.

Lisle, T.E., and Eads, R.E., 1991, Methods to measure sedimentation of spawning gravels: U.S. Forest Service, Pacific Southwest Research Station, Berkeley, California, Research Note PSW-411, 7 p.

Mahoney, J.M, and Rood, S.B., 1998, Streamflow requirements for cottonwood seedling recruitment-An integrative model: Wetlands, v. 18, no. 4, p. 634-645.

Major, J.J., O'Connor, J.E., Podolak, C.J., Keith, M.K., Grant, G.E., Spicer, K.R., Pittman, S., Bragg, H.M., Wallick, J.R., Tanner, D.Q., Rhode, A., and Wilcock, P.R., 2012, Geomorphic response of the Sandy River, Oregon, to removal of Marmot Dam: U.S. Geological Survey Professional Paper 1792, 64 p. and data tables, https://pubs. usgs.gov/pp/1792/.

Mangano, J.F., Piatt, D.R., Buccola, N.L., and Smith, C.D., 2018, Water surface elevations recorded by submerged water level loggers in off-channel features of the middle and upper Willamette River, Oregon, Summer, 2016: U.S. Geological Survey data release, https://doi.org/10.5066/ F77M06DV.

Mapes, R.L., Sharpe, C.S., and Freisen, T.A., 2017, Evaluation of the trap and transport of adult steelhead above USACE Project dams in the Upper Willamette Basin: Prepared by Oregon Department of Fish and Wildlife, Willamette Salmonid Research, Monitoring and Evaluation Program, Corvallis, Oregon, for U.S. Army Corps of Engineers, Portland Oregon, 35 p.

Marineau, M., Minear, J., and Wright, S., 2015, Using hydrophones as a surrogate sediment monitoring technique to detect temporal and spatial variability in bedload sediment transport: Proceedings of the SEDHYD2015 Joint 10th Federal Interagency Sedimentation Conference and the 5th Federal Hydrologic Modeling Conference, Reno, Nevada, April 19-23, 2015, 12 p.

McDowell, Patricia, and Dietrich, James, 2012, Willamette Sustainable River Project phase 2-Development of a monitoring plan for environmental flow recommendation on the Middle Fork Willamette River, Oregon: Eugene, Oregon, Final Report completed for the U.S. Army Corps of Engineers, $37 \mathrm{p}$.
Means, J.E., Acker, S.A., Fitt, B.J., Renslow, M., Emerson, L., and Hendrix, C.J., 2000, Predicting forest stand characteristics with airborne scanning lidar: Photogrammetric Engineering and Remote Sensing, v. 66, no. 11, p. 1367-1371.

Minear, P.J., 1994, Historical change in channel form and riparian vegetation of the McKenzie River, Oregon: Corvallis, Oregon State University, M.S. thesis, 175 p., 24 figs.

Moody, J.A., 1999, Ontogeny of a floodplain: GSA Bulletin, v. 111, no. 2, p. 291-303.

Montgomery, D.R., Buffington, J.M., Peterson, N.P., SchuettHames, David, and Quinn, T.P., 1996, Stream-bed scour, egg burial depths, and the influence of salmonid spawning on bed surface mobility and embryo survival: Canadian Journal of Fisheries and Aquatic Sciences, v. 53, p. 10611070.

Mosbrucker, A.R., Major, J.M., Spicer, K.R., and Pitlick, John, 2017, Camera system considerations for geomorphic applications of SfM photogrammetry: Earth Surface Processes and Landforms, v. 42, no. 6, p. 969-986.

National Marine Fisheries Service, 2008, Endangered Species Act section 7(a)(2) consultation biological opinion and Magnuson-Stevens Fishery Conservation and Management Act essential fish habitat consultation on the Willamette River Basin Flood Control Project: National Marine Fisheries Service, Northwest Region, Seattle, Washington, National Oceanic and Atmospheric Administration Fisheries Log Number FINWR12000/02117 [9-83], accessed April 9, 2013, at http://www.nwr.noaa.gov/hydropower/willamette opinion/index.html.

O'Connor, J.E., Jones, M.A., and Haluska, T.L., 2003, Flood plain and channel dynamics of the Quinault and Queets Rivers, Washington, USA: Geomorphology, v. 51, p. 31-59.

O’Connor, J.E., Mangano, J.F., Anderson, S.W., Wallick, J.R., Jones, K.L., and Keith, M.K., 2014, Geologic and physiographic controls on bed-material yield, transport, and channel morphology for alluvial and bedrock rivers, western Oregon: Geological Society of America Bulletin, v. 126, nos. 3-4, p. 377-397.

O’Connor, J.E., Sarna-Wojcicki, A., Wozniak, K.E., Polette, D.J., and Fleck, R.J., 2001, Origin, extent, and thickness of Quaternary geologic units in Willamette Valley, Oregon: U.S. Geological Survey Professional Paper 1620, 52 p. and digital data, dataset accessed September 5, 2017, at https:// or.water.usgs.gov/pubs_dir/Online/Cd/WRIR99-4036/ GIS_FILES/index.html. 
Oregon State University, 2013, PRISM climate data: Corvallis, Prism Climate Group, Oregon State University web site, accessed June 26, 2017, at http://www.prism.oregonstate. edu/.

Pacific Northwest Aquatic Monitoring Partnership, 2017, Monitoring resources glossary: Pacific Northwest Aquatic Monitoring Partnership web page, accessed August 18, 2018, at https://www.monitoringresources.org/Resources/ Glossary/Index.

Podolak, C.J., 2012, Channel bed response to an increased sediment supply: Baltimore, Maryland, Johns Hopkins University, Ph.D. dissertation, 129 p.

Podolak, C.J., and Wilcock, P.R., 2013, Experimental study of the response of a gravel streambed to increased sediment supply: Earth Surface Processes Landforms, v. 28, p. 1748-1764.

Polzin, M.L., and Rood, S.B., 2006, Effective disturbanceSeedling safe sites and patch recruitment of riparian cottonwoods after a major flood of a mountain river: Wetlands, v. 26, no. 4, p. 965-980.

Quantum Spatial, 2016, Middle Fork Willamette RiverTopobathymetric LiDAR 2015: Prepared by Quantum Spatial, Corvallis, Oregon, for Oregon Lidar Consortium, Oregon Department of Geology and Mineral Industries, Portland, Oregon, digital data and report, 33 p.

Quantum Spatial, 2017, Willamette River, Oregon Topobathymetric LiDAR Technical Data Report: Prepared by Quantum Spatial, Corvallis, Oregon for U.S. Army Corps of Engineers, Portland, Oregon, digital data and report, $43 \mathrm{p}$.

R2 Resource Consultants, Inc., 2014, FINAL_Evaluation of habitat-flow relationships for spring Chinook and winter steelhead in the North and South Santiam Rivers, Oregon: Prepared for U.S. Army Corps of Engineers, Portland District, 148 p.

Rathburn, S.L., Merritt, D.M., Wohl, E.E., Sanderson, J.S., Knight, H.A.L., 2009, Characterizing environmental flows for maintenance of river ecosystems - North Fork Cache la Poudre River, Colorado, in James, L.A., Rathburn, S.L., and Whittecar, G.R., eds., Management and restoration of fluvial systems with broad historical changes and human impacts: Boulder, Colorado, Geological Society of America, p. $143-157$.
Richter, B.D., Warner, A.T., Meyer, J.L., and Lutz, K., 2006, A collaborative and adaptive process for developing environmental flow recommendations: River Research and Applications, v. 22, no. 3, p. 297-318.

Rinaldi, M., 2003. Recent channel adjustments in alluvial rivers of Tuscany, central Italy: Earth Surface Processes and Landforms, v. 28, p. 587-608.

Risley, J.C., Bach, L., and Wallick, J.R., 2010, Summary report-Environmental flows workshop for the McKenzie River, Oregon: Portland, Oregon, The Nature Conservancy, $40 \mathrm{p}$.

Risley, J.C., Wallick, J.R., Mangano, J.F., and Jones, K.L, 2012, An environmental streamflow assessment for the Santiam River Basin, Oregon: U.S. Geological Survey Open-File Report 2012-1133, 66 p., accessed June 26, 2017 , at https:/pubs.usgs.gov/of/2012/1133/.

Risley, J.C, Wallick, J.R., Waite, I., and Stonewall, A., 2010, Development of an environmental flow framework for the McKenzie River Basin, Oregon: U.S. Geological Survey Scientific Investigations Report 2010-5016, 94 p., accessed June 26, 2017, at https://pubs.usgs.gov/sir/2010/5016/.

River Design Group, Inc., 2012, Middle Fork and Coast Fork Willamette River floodplain inundation mapping: Prepared for The Nature Conservancy, Corvallis, Oregon, 19 p. plus maps.

River Design Group, Inc., 2013, McKenzie River floodplain inundation mapping: Prepared for The Nature Conservancy, Corvallis, Oregon, 31 p. plus maps.

River Design Group, Inc., 2014, Middle Fork Willamette River, McKenzie River and South Fork McKenzie River target flows for PHABSIM analysis: Memorandum to U.S. Army Corps of Engineers, January 14, 2014, 13 p.

River Design Group, Inc., 2017, Santiam River Floodplain Inundation Mapping: Prepared for The Nature Conservancy, Portland, Oregon, 31 p., 14 maps.

River Design Group, Inc., and HDR, Inc., 2015, Evaluation of the relationship between river flow and fish habitat availability in the Middle Fork of the Willamette and McKenzie Rivers: Prepared for the U.S. Army Corps of Engineers, Portland District, 218 p.

Rood, S.B., Kalischuk, A.R., Polzin, M.L., and Braatne, J.H., 2003, Branch propagation, not cladoptsis, permits dispersive clonal reproduction of riparian cottonwoods: Forest Ecology and Management, v. 186, p. 227-242. 
Rood, S.B., Samuelson, G.M., Braatne, J.L., Gourley, C.R., Hughes, F.M.R., and Mahoney, J.M., 2005, Managing river flows to restore floodplain forests: Frontiers in Ecology and the Environment, v. 3, no. 4, p. 193-2001.

Roy, A.H., Rosemond, A.D., Leigh, D.S, Paul, M.J., and Bruce, J.W., 2003, Habitat-specific responses of stream insects to land cover disturbance-Biological consequences and monitoring implications: Journal of the North American Benthological Society, v. 22, no. 2, p. 292-307.

Schenk, E.R., Hupp, C.R., Richter, J.M., and Kroes, D.E., 2009, Bank erosion, mass wasting, water clarity, bathymetry, and a sediment budget along the dam-regulated lower Roanoke River, North Carolina: U.S. Geological Survey Open-File Report 2009-1260, 112 p.

Schenk, L.N., and Bragg, H.M., 2014, Assessment of suspended-sediment transport, bedload, and dissolved oxygen during a short-term drawdown of Fall Creek Lake, Oregon, winter 2012-13: U.S. Geological Survey Open-File Report 2014-1114, 80 p., accessed June 26, 2017 at, https:// dx.doi.org/10.3133/ofr20141114.

Sedell, J.R., and Froggatt, J.L., 1984, Importance of streamside forests to large rivers - The isolation of the Willamette River, Oregon, USA, from its floodplain by snagging and streamside forest removal: Verhandlungen der Internationale Vereinigung fur Theoretische und Angewandte Limnologie, v. 22, p. 1828-1834.

Schroeder, R.K., Kenaston, K.R., and McLaughlin, L.K., 2007, Spring Chinook salmon in the Willamette and Sandy rivers: Oregon Department of Fish and Wildlife Progress Reports 2006-2007, Project Number F-163-R-11/12, Fish Division, Salem, Oregon, 62 p.

Schroeder, R.K., Whitman, L.D., Cannon, B., and Olmsted, P., 2015, Juvenile life-history diversity and population stability of spring Chinook salmon in the Willamette River Basin, Oregon: Canadian Journal of Fisheries and Aquatic Sciences, v. 73, p. 921-934.

Shaff, C., Riher, J., and Campbell, J., 2007, OWEB guide to photo point monitoring: Oregon Watershed Enhancement Board, Salem, Oregon, 16 p., accessed June 26, 2017, at http://www.oregon.gov/OWEB/docs/pubs/photopoint monitoring_doc_july2007.pdf.
Sharpe, C.S., Mapes, R.L., Olmstead, P., Sinnott, M., DeBow, B., Bailey, E., Hoblit, T. and Freisen, T., 2017, Abundance, distribution, diversity and survival of adult spring Chinook salmon in the Upper Willamette River-2015 and 2016: Prepared by the Oregon Department of Fish and Wildlife, Willamette Salmonid Research, Monitoring, and Evaluation Program, Corvallis, Oregon, for U.S. Army Corps of Engineers, Portland, Oregon, $141 \mathrm{p}$.

Sidle, R.C., and Onda, Y., 2004; HydrogeomophologyOverview of an emerging science: Hydrological Processes, v. 18 , p. 597-602.

Stearns, H.T., 1928, Geology and water resources of the Upper McKenzie Valley, Oregon, in Grover, N.C., ed., Contributions to the hydrology of the United States: U.S. Geological Survey Water Supply Paper 597-D, p. 171-188.

Steiger, J., Gurnell, A.M., and Goodson, J.M., 2003, Quantifying and characterizing contemporary riparian sedimentation: River Research and Applications, v. 19, p. $335-352$.

Stonewall, A.J., and Buccola, N.L., 2015, Development of a HEC-RAS temperature model for the North Santiam River, northwestern Oregon: U.S. Geological Survey Open-File Report 2015-1006, 26 p.

Surian, N., and Rinaldi, M., 2003, Morphological response to river engineering and management in alluvial channels in Italy: Geomorphology, v. 50, p. 307-326, https://doi. org/10.1016/S0169-555X(02)00219-2.

Surian, N., Ziliani, L., Comiti, F., Lenzi, M.A., and Mao, L., 2009, Channel adjustments and alteration of sediment fluxes in gravel-bed rivers of north-eastern Italy-Potential and limitations for channel recovery: River Research Applications, v. 25, p. 551-567, https://doi.org/10.1002/ rra.1231.

Tague, C., and Grant, G.E., 2004, A geological framework for interpreting the low flow regimes of Cascade streams, Willamette River Basin, Oregon: Water Resources Research, v. 40, no. 4, 9 p., https://doi. org/10.1029/2003WR002629.

Tappel, P.D., and Bjorn, T.C., 1983, A new method of relating size of spawning gravel to salmonid embryo survival: North American Journal of Fisheries Management, v. 3, p. 123-135. 
Tharme, R.E., 2003, A global perspective on environmental flow assessment-Emerging trends in the development and application of environmental flow methodologies for rivers: River Research and Applications, v. 19, p. 397-441, https:// doi.org/10.1002/rra.736.

The Nature Conservancy, 2017, The sustainable rivers project: The Nature Conservancy web page, accessed August 29, 2017, at https://www.nature.org/ourinitiatives/habitats/ riverslakes/sustainable-rivers-project.xml.

U.S. Army Corps of Engineers, 2007, Supplemental biological assessment of the effects of the Willamette River Basin flood control project on species listed under the Endangered Species Act: U. S. Army Corps of Engineers, Portland District, Submitted to National Marine Fisheries Service and U.S. Fish and Wildlife Service [variously paged], accessed June 3, 2009, http://www.nwp.usace.army.mil/ pm/e/en_plan_ba.asp.

Wallick, J.R., Anderson, S.W., Cannon, C., and O'Connor, J.E., 2010, Channel change and bed-material transport in the lower Chetco River, Oregon: U.S. Geological Survey Scientific Investigations Report 2010-5065, 68 p., accessed June 26, 2017, at https://pubs.usgs.gov/sir/2010/5065/.

Wallick, J.R., Grant, G.E., Lancaster, S.T., Bolte, J.P., and Denlinger, R.P., 2007, Patterns and controls on historical channel change in the Willamette River, Oregon, in Gupta, A.V., ed., Large rivers - Geomorphology and management: Chichester, United Kingdom, Wiley, p. 491-516.

Wallick, J.R., Jones, K.L., O'Connor, J.E., and Keith, M.K., Hulse, D., and Gregory, S.V., 2013, Geomorphic and vegetation processes of the Willamette River floodplain, Oregon-Current understanding and unanswered questions: U.S. Geological Survey Open-File Report 2013-1246, 70 p., accessed June 26, 2017, at https://dx.doi.org/10.3133/ ofr20131246.
Wallick, J.R., Lancaster, S.T., and Bolte, J.P., 2006, Determination of bank erodibility for natural and anthropogenic bank materials using a model of lateral migration and observed erosion along the Willamette River, Oregon, USA: River Research and Applications, v. 22, p. 631-649.

Wallick, J.R., O'Connor, J.E., Anderson, S., Keith, M., Cannon, C., and Risley, J.C., 2011, Channel change and bed-material transport in the Umpqua River Basin, Oregon: U.S. Geological Survey Scientific Investigations Report 2011-5041, 112 p., accessed June 26, 2017, at https://pubs. usgs.gov/sir/2011/5041/.

Warner, A.T., Bach, L.B., and Hickey, J.T., 2014, Restoring environmental flows through adaptive reservoir management-Planning, science, and implementation through the Sustainable Rivers Project: Hydrological Sciences, v. 59, nos. 3-4, p. 770-785.

Wilcock, P., Pitlick, John, and Cui, Y., 2009, Sediment transport primer estimating bed-material transport in gravelbed rivers: U.S. Forest Service, Rocky Mountain Research Station, General Technical Report RMRS-GTR-226, 78 p.

Wilcock, P.R., 1997, Entrainment, displacement, and transport of tracer gravels: Earth Surface Processes and Landforms, v. 22, p. 1125-1138.

Wheaton, J.M., Brasington, J, Darby, S.E., and Sear, D.A., 2010, Accounting for uncertainty in DEMs from repeat topographic surveys - Improved sediment budgets: Earth Surface Processes and Landforms: v. 35, no. 2, p. 136-156.

Wohl, E., Bledsoe, B.P., Jacobson, R.B., Poff, N.L., Rathburn, S.L., Walters, D.M., and Wilcox, A.C., 2015, The natural sediment regime in rivers-Broadening the foundation for ecosystem management: BioScience, v. 65, p. 963-972.

Wolman, M.G., and Miller, J.P., 1960, Magnitude and frequency of forces in geomorphic processes: Journal of Geology, v. 68, p. 54-74. 


\title{
Appendix 1. Reach Characteristics and Monitoring Considerations
}

\author{
Reach name and boundaries Upper Middle Fork Willamette River: Fall Creek confluence to Dexter Dam (Floodplain \\ kilometers [FPKMs] 15-22; table 1; fig. 3; also referred to as the Dexter reach in Jones and \\ others [2016])
}

\author{
Hydrologic alteration, \\ streamflow conditions, and \\ bed-material flux
}

\section{Geomorphic and vegetation conditions}

\section{Monitoring zones that are laterally dynamic}

Laterally stable monitoring zones with mature vegetation and relict side-channels

Considerations for conducting the hydrogeomorphic monitoring activities described in tables 3 and 5
Insufficient pre-dam streamgage period of record for comparison, but streamflow alteration is greater for this reach than for others in study owing to lack of unregulated tributary inputs and because flow in this reach is regulated by two large upstream flood control reservoirs (Lookout Point Dam-1953, and Hills Creek Dam-1961) and one re-regulating dam (Dexter Dam-1954). Dexter streamgage downstream of the dams has short period of record. See the following table for downstream Jasper streamgage reference. Upstream dams trap all bed sediment that historically entered reach from upstream areas.

This reach has little revetment but is geomorphically stable because of reductions in peak flows, coarse sediment inputs, and subsequent vegetation encroachment and local bedrock controls. Prior to dam construction in 1950s, the reach was a multi-thread, laterally dynamic wandering gravel-bed river with nearly continuous, large, bare, active gravel bars and numerous side-channels. Presently, the channel is predominantly single thread and laterally stable with a few relict side-channels near FPKMs 15-17 and 20-22. Active gravel bars are small (less than 5,000 square meters) and sparse, and typically are situated in segments with localized bank erosion, resulting in few areas for cottonwood recruitment. Former bare gravel bars now have dense, mature forests that extend nearly to the low-flow channel margin.

FPKMs 15-17 near the mouth of Fall Creek have actively shifting bare gravel bars and secondary channels and areas with active bank erosion.

FPKMs 15-17 and 19-21 have an extensive network of relict side-channels flanked by dense, mature forest. Low-elevation bars with moderately dense vegetation established after the 1996-97 floods within both areas.

Inundation monitoring could focus on extent and duration of side-channel inundation at different flows to target specific species of interest (for example Oregon chub [Oregonicthys crameri]) and could incorporate Oregon Department of Fish and Wildlife, The Nature Conservancy (TNC), and U.S. Army Corps of Engineers (USACE) monitoring efforts. Streamflow in this reach is available from the U.S. Geological Survey (USGS) streamgage at Dexter (14150000). Because of extensive vegetation encroachment, floodplains and stable bars likely will remain stable except in exceptional floods; geomorphic monitoring focus could be in the active channel where changes in gravel bars, grain sizes, and low-elevation side-channels are likely to be greatest. Monitoring priorities could include (1) tracking changes in channel features such as bars and secondary channels to assess gains and losses in important habitat features, (2) evaluating influence of flow duration and hydrograph shape in determining patterns of bank erosion and channel change for sub-bankfull events, and (3) tracking changes in bed elevation in main channel and off-channel areas.

Considerations for conducting the vegetation monitoring activities described in tables 4 and 5

References
Vegetation recruitment appears particularly limited by a lack of bare bar surfaces that are suitable for stand initiation. Vegetation monitoring could focus on (1) tracking areas of active vegetation recruitment and establishment, (2) evaluating trajectories of existing vegetation stands, and (3) determining flow needed to reset mature vegetation and create new bar surfaces.

Gregory and others (2007a, 2007b); Dykaar (2005, 2008a, 2008b); Wallick and others (2013); O'Connor and others, 2014; Jones and others (2016) 

Reach name and boundaries Lower Middle Fork Willamette River: Mouth to Fall Creek confluence (FPKMs 0-15; table 1; fig. 3; also referred to as the Jasper and Confluence reaches in Jones and others [2016])

Flow is regulated by three flood control reservoirs (Lookout Point Dam-1953, Hills Creek Dam—1961, and Fall Creek Dam-1966) and one reregulating dam (Dexter Dam—1954). Regulation has reduced small floods (2-year recurrence interval) by nearly 50 percent from 39,300 to 20,000 cubic feet per second $\left(\mathrm{ft}^{3} / \mathrm{s}\right)$ at the Jasper streamgage. Pre-dam large floods (10-year recurrence interval, $82,100 \mathrm{ft}^{3} / \mathrm{s}$ ) have been eliminated, and the highest flows since 1965 were 23,300 ft $3 / \mathrm{s}$ on December 25, 1996. Sustainable Rivers Project stakeholders recommended that bankfull flows at the Jasper streamgage range from 19,000 to 20,000 $\mathrm{ft}^{3} / \mathrm{s}$ (with some stakeholders suggesting bankfull flows are closer to $25,000 \mathrm{ft}^{3} / \mathrm{s}$; Gregory and others, 2007b). Typical peak flows are about 15,000-18,000 ft³.s. Summer base flows have increased 2-3 times from the unregulated summer flows. Upstream dams trap about 95 percent of bedload that historically entered the reach (O'Connor and others, 2014).

Geomorphic and vegetation conditions

\section{Monitoring zones that are laterally dynamic}

Laterally stable monitoring zones with mature vegetation and relict side-channels

Considerations for conducting the hydrogeomorphic monitoring activities described in tables 3 and 5
Locally, this reach is more laterally dynamic than the upper Middle Fork Reach, but overall, the reach is predominantly stable owing to substantial reductions in peak flows, coarse sediment inputs, bedrock outcrops, and local revetments. The historically multi-threaded, wandering channel with large, bare gravel bars is now primarily single thread with a few actively shifting gravel bars that range in size to as large as $6,000 \mathrm{~m}^{2}$. Slight channel shifting was observed from 2005 to 2012 near FPKMs 0, 3-4, and 15, where channel complexity is greatest and where gravel bars are actively growing and changing position. Increased dynamism at FPKM 15 occurs near the mouth of Fall Creek, whereas dynamism near FPKMs 4-7 is partly influenced by restoration activities at the TNC Willamette Confluence Preserve where levee modifications and channel restoration activities were designed to support geomorphic processes and habitat creation. Reach-scale stability since dam construction has resulted in a narrow active channel with few areas suitable for cottonwood recruitment. Along much of the reach, dense, mature forest now covers formerly active bare gravel bars, extending nearly to the low-flow channel margin.

FPKMs 3-4 near the TNC Willamette Confluence Preserve site has bare, actively shifting bars and side-channels and ongoing bank erosion.

FPKM 7 has a large bar with moderately dense vegetation established after the 1996-97 floods. This bar could be more easily mobilized by future high-flow events than other areas with denser, more mature vegetation. FPKM 11 also has surfaces mobilized by 1996-97 floods, along with relict side-channels.

Inundation monitoring could focus on extent and duration of side-channel connectivity and floodplain inundation at different flows and could incorporate TNC monitoring efforts at the Willamette Confluence Preserve site. Streamflow in this reach is available from the USGS streamgage at Jasper (14152000). Repeat mapping of the active channel in 2005 and 2011 (McDowell and Dietrich, 2012; Jones and others, 2016) provides baseline datasets for evaluating future changes. Substantial sediment delivery from the drawdown of Fall Creek Reservoir beginning in 2011 (Schenk and Bragg, 2014; Keith and others, 2017) may obscure effects of environmental flow releases (Jones and others, 2016). Monitoring priorities could include (1) tracking changes in channel features such as bars and secondary channels to assess gains and losses in important habitat types, (2) evaluating influence of flow duration and hydrograph shape in determining patterns of bank erosion and channel change for subbankfull events, and (3) tracking changes in bed elevation in main channel and off-channel areas.

Considerations for conducting the vegetation monitoring activities described in tables 4 and 5

\section{References}

Vegetation monitoring could focus on (1) tracking vegetation recruitment and establishment along the active gravel bars near FPKMs 3-4, (2) tracking evolution of vegetation established after the 1996-97 floods, and (3) reach-wide census of young (10-20-year-old) cottonwoods to determine hydrogeomorphic conditions that support establishment.

Gregory and others (2007a; 2007b); Dykaar (2005, 2008a; 2008b); Wallick and others (2013); O'Connor and others, (2014); Jones and others (2016); 


\begin{tabular}{ll}
\hline Reach name and boundaries & $\begin{array}{l}\text { Upper McKenzie River: Hayden Bridge to Deerhorn (FPKMs 14-35; table 1; fig. 4; also } \\
\text { referred to as reaches 9, 10, and } 11 \text { in Risley, Wallick and others [2010]) }\end{array}$
\end{tabular}

Hydrologic alteration,
streamflow conditions, and
bed material-flux

Flow has been regulated since 1963 by Carmen-Smith Hydroelectric Project and Cougar Reservoir and since 1968 by Blue River Reservoir. Regulation has reduced small flood discharge (2-year recurrence interval) at Vida streamgage (15 kilometers [km] upstream of reach) by 40 percent from 28,740 to $17,210 \mathrm{ft}^{3} / \mathrm{s}$ and large flood discharge (10-year recurrence interval) from 40,320 to $27,400 \mathrm{ft}^{3} / \mathrm{s}$. Post-regulation 7-day minimum annual streamflow increased 125 percent at Vida streamgage. Leaburg Dam and upstream USACE dams trap nearly all bed material entering the reach (O'Connor and others, 2014). Municipal and industrial withdrawals, including diversion of flow through the Walterville Canal, may influence summer streamflow.

\section{Geomorphic and vegetation conditions}

\author{
Monitoring zones that are \\ laterally dynamic
}

\section{Laterally stable monitoring zones with mature vegetation and relict side-channels} the hydrogeomorphic monitoring activities described in tables 3 and 5
Considerations for conducting

Historically, the channel was a wandering gravel-bed river with large bare, actively shifting bars and flow divided among multiple side-channels (Risley, Wallick and others, 2010). Presently, overall planform is that of a wandering channel, although the channel is predominantly single-thread, with substantial reductions in side-channels. Many formerly bare bars and islands are now stabilized with mature vegetation. This reach has some laterally dynamic sections with active bank erosion and actively shifting bars, but is predominantly laterally stable owing to revetments and naturally resistant bank materials. Floodplain surfaces are relatively low and easily inundated by 2-year recurrence interval flood (River Design Group, Inc., 2012). Most of the channel is flanked by dense, mature forest that varies from 300 to $700 \mathrm{~m}$ in width, but laterally dynamic areas such as FPKMs 19-24 have patchier, diverse stands of vegetation at different seral stages. This reach has considerable channel complexity and lower elevation floodplains than the downstream reach.

Series of meander bends along FPKMs 19-24 have bare, actively shifting bars and sidechannels and limited revetment. The McKenzie Oxbow site near FPKM 25 is a long-term site for monitoring Oregon chub was studied by Jones and others (2016), and part of the area is managed for conservation by McKenzie River Trust.

FPKMs 19, 28 and 34 have secondary channels and low elevation bars that are primarily stabilized by mature forest. Limited revetment is in these areas. The Big Island site (FPKM 19) is a conservation site managed by McKenzie River Trust and other organizations and has baseline habitat and vegetation data.

The existing channel complexity and relative dynamism of this reach make it a good candidate for evaluating year-round relations between flow, geomorphology, and vegetation. Additionally, the McKenzie River Basin supports an important population of wild spring Chinook salmon (National Marine Fisheries Service, 2008), so monitoring could focus on verifying the flow conditions that support spawning and rearing habitats and tracking changes in the habitat availability that relate to streamflows and geomorphic processes. Discharge can be monitored using the USGS streamgages on McKenzie River at Walterville (14163900), Hayden Bridge (14164900), and Coburg (14165500). Municipal and industrial withdrawals influence streamflow, although the largest diversions are for the Eugene Water and Electric Board Walterville and Leaburg canals where most of the water is returned to main-stem McKenzie River (Risley, Wallick and others, 2010).

Considerations for conducting the vegetation monitoring activities described in tables 4 and 5

References
Several areas along this reach appear to support all phases of stand initiation and vegetation succession (Jones and others, 2016). Future detailed, field-based studies at sites such as FPKMs 19-24 could build upon these initial findings to evaluate conditions necessary for stand initiation, establishment, and succession in different settings, and findings could potentially be transferable to other sites along the McKenzie River and other tributaries. 


\begin{tabular}{ll}
\hline Reach name and boundaries & $\begin{array}{l}\text { Lower McKenzie River: Mouth to Hayden Bridge (FPKMs 0-14; table 1; fig. 4; also } \\
\text { referred to as reaches } 10 \text { and } 11 \text { in Risley, Wallick and others [2010]) }\end{array}$ \\
\hline $\begin{array}{l}\text { Hydrologic alteration, } \\
\text { streamflow conditions, and } \\
\text { bed-material flux }\end{array}$ & $\begin{array}{l}\text { See previous section for Upper McKenzie River reach for flow regulation. Post-regulation } \\
\text { 7-day minimum annual streamflow increased 122 percent at Coburg streamgage. Coarse bed } \\
\text { material that would have entered this reach from upstream has been reduced by } 83 \text { percent } \\
\text { (O'Connor and others, 2014). }\end{array}$
\end{tabular}

\author{
Geomorphic and vegetation \\ conditions
}

\begin{abstract}
Monitoring zones that are laterally dynamic
\end{abstract}

\section{Laterally stable monitoring zones with mature vegetation and relict side-channels}

Considerations for conducting the hydrogeomorphic monitoring activities described in tables 3 and 5
Channel is predominantly single-thread, with few active gravel bars; it is somewhat dynamic near the mouth, but elsewhere reach is stable owing to local geology or revetments. Secondary channels are most numerous at the mouth and near FPKM 9. Floodplain is relatively high compared to active channel, with limited overbank flooding from 2-year recurrence interval flood. The reach primarily contains areas devoid of trees or areas where channel is flanked by dense, mature forest corridor that is as wide as $600 \mathrm{~m}$; there are very few areas with young or patchy vegetation. Cottonwood recruitment is limited by few bare bars for stand initiation, and most bare bars appear frequently re-set by high flows that hinder the establishment of young vegetation.

The Springfield Oxbow site near FPKM 8 is a good candidate for future monitoring because it has large, actively shifting bars flanked by stable mature vegetation and is managed by the McKenzie River Trust (MRT), which has been overseeing other monitoring at the site (J. Lemmer, McKenzie River Trust, oral commun., April 1, 2015). Dynamic areas in FPKMs $0-5$ are constrained by bank stabilization near gravel mining operations.

FPKMs 5 and 7 have low elevation bars with mature vegetation that may get re-set by high flows. FPKM 7 has relict side-channels.

Given current reach stability, monitoring could focus on establishing more robust relations between discharge and inundation extent (to refine flow targets for connecting off-channel features) and optimizing hydraulic conditions in existing channel features. Much of floodplain is relatively high in elevation compared to the channel and may not be inundated by 2-year recurrence interval floods (River Design Group, Inc., 2013). Monitoring could confirm inundation patterns and could be used to identify side-channels that are inundated at different magnitude flows. Discharge can be evaluated using the USGS streamgage at Hayden Bridge (14164900) in combination with flow inputs from Mohawk River (14165000 near Springfield) and withdrawals for municipal and industrial uses. This reach has had substantial historical incision, which could influence current and future habitat availability.

Considerations for conducting the vegetation monitoring activities described in tables 4 and 5

References
Currently, there appears to be limited recruitment of young stands of riparian vegetation in this reach; therefore, detailed monitoring of all phases of vegetation succession could focus on the upstream reach. More basic monitoring, such as mapping geomorphic surfaces suitable for stand initiation, could be used to identify important factors limiting vegetation recruitment in this reach and determine how environmental flows may improve these limiting factors.

Risley, Bach and Wallick (2010); Risley, Wallick and others (2010); River Design Group, Inc. (2013); Wallick and others (2013) 
Reach name and boundaries South Santiam River: Downstream of Lebanon to confluence with North Santiam River

(FPKMs 0-20; table 1; fig. 6; also referred to as reach 6 in Risley and others [2012])

Hydrologic alteration, streamflow conditions, and bed-material flux

\section{Geomorphic and vegetation conditions}

\section{Monitoring zones that are laterally dynamic}

Laterally stable monitoring zones with mature vegetation and relict side-channels

Considerations for conducting the hydrogeomorphic monitoring activities described in tables 3 and 5
Flow has been regulated since 1966 by Green Peter Lake and Foster Lake. Regulation has reduced small flood discharge (1.5-year recurrence interval) at the Waterloo streamgage from 31,500 to $14,200 \mathrm{ft}^{3} / \mathrm{s}$ and large flood discharge (10-year recurrence interval) from 65,600 to $20,900 \mathrm{ft}^{3} / \mathrm{s}$. Seven-day minimum annual streamflows have increased 335 percent after regulation. Prior to regulation, bankfull flows $\left(18,000 \mathrm{ft}^{3} / \mathrm{s}\right.$ at Waterloo) were exceeded about 4 days per year, but from 1967 to 2011, bankfull flows occurred less than once every 5 years. One flood (February 6, 1997; 24,200 ft 3 s) occurred within the regulation era. Coarse bed material that would have entered this reach from upstream has been reduced by 87 percent (O'Connor and others, 2014).

Channel is predominantly single-thread, with stable meander bends flanked by revetments; there are few side-channels or active gravel bars except downstream of the confluence of Thomas and Crabtree Creeks where several bends are actively migrating. Although much of the reach is stabilized by extensive revetments, several individual bends near FPKMs 10-11 have large (greater than 10,000 $\mathrm{m}^{2}$ ), active bars indicating recent bed material transport. Riparian vegetation ranges from revetted reaches flanked by agricultural lands with scant floodplain forest to segments such as FPKMs 10-12 where the riparian forest is 300-700 $\mathrm{m}$ wide. Most of the forested areas are densely vegetated with mature trees and little spatial heterogeneity. The combination of few bare gravel bars and abundant mature trees indicates limited recruitment of young forest stands; exceptions include near FPKMs 10-11 where bands of even-aged young woody vegetation indicate successful recruitment and succession with progressive meander growth. Given extensive revetments and limited areas where geomorphic processes are actively forming new bars and side-channels, this reach may be prone to future losses in off-channel habitats as relict side-channel fill with fine sediment. The geomorphic effects of high flows also are uncertain, as revetted reaches might be prone to incision and substrate coarsening, whereas freely migrating bends might erode mature forest, supporting the formation of gravel bars and increases of in-channel large wood.

FPKMs 0-5 near confluence of Crabtree and Thomas Creeks have active gravel bars and some active side-channels. FPKMs 11-12 have large bars and actively shifting meander bends.

Series of meander bends along FPKMs 10-11 have a wide (500-m) corridor to migrate between revetments and relict side-channels. Stabilizing vegetation could be reset by future erosion.

Considering that the South Santiam River supports important populations of wild spring Chinook salmon and winter steelhead, (National Marine Fisheries Service, 2008), monitoring could focus on evaluating flow conditions that support spawning and year-round rearing habitats. Monitoring of high flows could focus on active channel and low-elevation floodplains, as flood inundation likely will be restricted to riparian forest corridor (based on extent of 1996 flood inundation). Streamflows in this reach can be evaluated using the USGS streamgage at Waterloo (14187500; $10 \mathrm{~km}$ upstream of reach) and accounting for withdrawals from the Lebanon-Albany canal. Monitoring downstream of FPKM 5 should account for flow inputs from the USGS streamgage on Thomas Creek, and Crabtree Creek (ungaged).

At the reach-scale, there appear to be few stands of young cottonwood. Initial monitoring could verify the status of vegetation recruitment and identify primary factors that may be limiting recruitment. Once these factors are better understood, future monitoring tasks could be tailored accordingly. For example, there are some areas of active meander migration that could support vegetation recruitment, but it is currently unclear whether recruitment is limited by high flows that re-set young vegetation or if flows during spring and summer limit recruitment by causing mortality of young seedlings.

Bach and others, 2013; Risley and others (2012); Wallick and others (2013); River Design Group (2017) 


\section{Reach name and boundaries North Santiam River: Mouth to Stayton (FPKMs 0-20; table 1; fig. 5; also referred to as reach 3 in Risley and others [2012])}

Hydrologic alteration,
streamflow conditions, and
bed-material flux

Geomorphic and vegetation conditions

\section{Monitoring zones that are laterally dynamic}

Laterally stable monitoring zones with mature vegetation and relict side-channels

Considerations for conducting the hydrogeomorphic monitoring activities described in tables 3 and 5

Considerations for conducting the vegetation monitoring activities described in tables 4 and 5

References
Flow had been regulated since 1953 by Detroit Lake and Big Cliff Reservoir. Regulation has reduced small flood discharge (1.5-year recurrence interval) at the Mehama streamgage from 28,500 to $17,800 \mathrm{ft}^{3} / \mathrm{s}$ and large flood discharge (10-year recurrence interval) from 58,300 to $32,700 \mathrm{ft}^{3} / \mathrm{s}$. Seven-day minimum annual streamflows have increased 95 percent after regulation. Prior to regulation, flow exceeded bankfull threshold $\left(17,000 \mathrm{ft}^{3} / \mathrm{s}\right) 3-4$ times per year, but since 1952, bankfull flows occur slightly less than once per year. Post-regulation floods exceeding the 10-year recurrence interval have occurred twice when peak flows were 36,200 and 46,700 ft³/s (December 22, 1964 and February 7, 1996, respectively). Coarse bed material that would have entered this reach from upstream has been reduced by 62 percent (O’Connor and others, 2014).

This reach is more dynamic than other reaches, with active meander migration and avulsions, especially between FPKMs 5-12. There are extensive multi-channeled segments alternating with single-thread segments and a diverse array of secondary channels ranging from recently formed alcoves to more stable side-channels. The reach has numerous active gravel bars as large as $60,000 \mathrm{~m}^{2}$, especially at FPKMs 5-12; these are larger and more numerous than those at other study reaches. Revetments and resistant Pleistocene terraces limit local bank erosion in some areas. Aerial photographs indicate many areas with active vegetation recruitment and different ages of riparian forest. Channel dynamism on this reach creates more opportunities for cottonwood recruitment.

FPKMs 5-12 compose the most dynamic segment within the reach, with continuous, large actively shifting gravel bars and numerous active side-channels. Other segments, such as FPKM 17, also have bare bars and active bank erosion.

Much of the reach has minimal revetment, extensive relict side-channels, and mature vegetation, but FPKMs 17 and 25 are good candidates for monitoring because they have relatively limited bar growth and erosion. FPKM 17 coincides with a part of the Chahalpam conservation site.

The lower part of the reach (FPKMs 0-17) is relatively dynamic compared with other reaches, and a diverse array of habitats appear to be created and maintained under current conditions. Monitoring could verify these conditions and the flows that best support current geomorphic processes; monitoring also could track the status of channel features in this reach to determine if losses occur and if they are related to flow management. The North Santiam River supports important populations of wild spring Chinook salmon and winter steelhead (National Marine Fisheries Service, 2008), and monitoring could focus on evaluating flow conditions that support spawning and year-round rearing habitats. Streamflows in this reach can be evaluated using the USGS streamgage at Mehama (14183000). Monitoring needs to account for irrigation and municipal water withdrawals, which significantly influence summer streamflows. Flood inundation likely will be restricted to the main channel and side-channels (based on 1996 flood extent), but monitoring could help establish the magnitude of discharge needed to inundate different types of side-channels. Although this reach has had more dynamism than other reaches, the main channel in FPKMs 5-10 is flowing along resistant Pleistocene terrace, which could exert a stabilizing influence on channel morphology (Wallick and others, 2006). Repeat mapping of channel change and bank erosion would help verify that this segment is continuing to create and renew a diverse array of riparian habitats.

The North Santiam is a good reach to monitor all phases of vegetation recruitment and succession because there are many areas (such as FPKMs 5-10) with vegetation at different seral stages. Channel dynamism in this reach makes this a good candidate for evaluating the hydraulic conditions necessary to re-set different stages of vegetation.

Bach and others, 2013; Risley and others (2012); Wallick and others (2013); River Design Group (2017) 


\begin{tabular}{ll}
\hline Reach name and boundaries & $\begin{array}{l}\text { Santiam River: Mouth to confluence of North and South Santiam Rivers (FPKMs 0-11; } \\
\text { table 1; fig. 6; also referred to as reach } 7 \text { in Risley and others [2012]) }\end{array}$
\end{tabular}

Hydrologic alteration, streamflow conditions, and bed material flux

Geomorphic and vegetation conditions
Flow has been regulated since 1953 by Detroit Lake and Big Cliff Reservoir, and since 1966 by Green Peter Lake and Foster Lake. Regulation has reduced small flood discharge (1.5-year recurrence interval) at the Jefferson streamgage from 62,400 to $44,200 \mathrm{ft}^{3} / \mathrm{s}$ and large flood discharge (10-year recurrence interval) from 152,000 to $102,000 \mathrm{ft}^{3} / \mathrm{s}$. Sevenday minimum annual streamflows have increased 237 percent after regulation. Prior to regulation, bankfull flows $\left(35,000 \mathrm{ft}^{3} / \mathrm{s}\right.$ at Jefferson streamgage) were exceeded more than 7 times per year; but during 1953-2011, daily flows exceeded bankfull only about 4 times per year. There have been at least 4 floods exceeding $62,000 \mathrm{ft}^{3} / \mathrm{s}$ since full regulation in 1967, including the February 7, 1996 flood of 115,000 ft $3 / \mathrm{s}$. Coarse bed material that would have entered this reach from upstream has been reduced by 62 percent (O'Connor and others, 2014).

This is a single-thread channel with an extensive network of relict side-channels along the entire reach. Active gravel bars are sparse except near FPKMs 0 and 7, where there are large active gravel bars. The narrow active channel with few active gravel bars and extensive revetment has limited cottonwood recruitment and decreased spatial heterogeneity of riparian plant communities. Although there are a few bare bars for vegetation recruitment, these surfaces appear to be frequently mobilized, which may limit cottonwood recruitment. The width of the riparian corridor varies from 400 to $700 \mathrm{~m}$ in width and primarily consists of mature trees along the channel margins and relict bars.

FPKMs $0-3$ have bare bars and areas of active vegetation recruitment and succession.

\section{Monitoring zones that are laterally dynamic}

Laterally stable monitoring zones with mature vegetation and relict side-channels

Considerations for conducting the hydrogeomorphic monitoring activities described in tables 3 and 5

\section{Considerations for conducting} the vegetation monitoring activities described in tables 4 and 5

References
FPKMs 0-5 have numerous relict side-channels and forested bars that may be sensitive to future flow fluctuations. FPKM 1 has a low-elevation bar with moderate vegetation and older alcoves.

Considering that the main-stem Santiam River has both stable and more dynamic areas, monitoring could focus on determining relations between flows, water levels, and inundation patterns in existing channel features (such as side-channels), rather than on flows to create new habitats. The Santiam River is an important corridor for wild spring Chinook salmon and winter steelhead that spawn in the North and South Santiam Rivers, (National Marine Fisheries Service, 2008), and monitoring also could focus on evaluating flow conditions that support migration and year-round rearing habitats.

At high flows, inundation patterns and water levels near the mouth of the Santiam River can be influenced by backwater from the Willamette River; inundation monitoring could focus on areas upstream of the confluence where relations between Santiam River streamflow and inundation patterns are clearer. The streamgage at Jefferson (14189000) is sufficient for evaluating discharge for the Santiam River, although withdrawals for irrigation and other purposes could influence streamflows downstream of the streamgage, especially during summer low-flow season.

Vegetation monitoring could target dynamic monitoring zones where stand initiation and establishment are most likely to occur. Extensive riparian forests near the mouth of the Santiam River may be good locations for long-term monitoring to track status and trends of these sites.

Bach and others, 2013; Risley and others (2012); Wallick and others (2013); River Design Group (2017) 


\section{Appendix 2. Examples of Techniques for Evaluating and Documenting Flow Characteristics}

Environmental flow targets propose magnitude frequency, duration, and timing of flow. These flows in turn support key physical and biological processes. In some cases, it will be important to evaluate flow targets and compare them to the environmental flow components and objectives to validate the environmental flow releases and understand hydrologic processes such as rate of change of flow.

Evaluating the extent to which actual flows meet Sustainable Rivers Project (SRP) flow recommendations requires comparisons between observed streamflow and SRP targets (which generally are defined in terms of the timing, magnitude, duration, and frequency of flow events). Streamgages in, or near, each reach can provide information for these comparisons (appendix 1). At some locations, withdrawals for municipal or irrigation use also must be considered, especially during low flow periods when such withdrawals may substantially influence streamflow in the reach (table 2; appendix 1).

Specific approaches for evaluating hydrograph characteristics and implementation of the environmental flow program could include the following:

- Compiling daily streamflow data and comparing to environmental flow components for each season. Streamflow data can be analyzed to determine the frequency, duration, magnitude, and timing of each event to evaluate individual environmental flow components. Recession rates for peak or pulse flows also can be computed. This hydrologic data can be used to assess streamflow conditions along specific reaches, or used in conjunction with hydraulic, geomorphic, or vegetation monitoring at specific monitoring zones or transects (appendix 1). Measured streamflow also can be compared with environmental flow targets from the environmental flow workshops. To date, standardized protocols for defining and quantifying flow targets have not been developed. SRP implementation and monitoring in the Willamette River Basin would benefit from the development of standardized protocols.
- Accurately characterize peak flows and low flows. Accurate peak flow could be obtained by evaluating unit flow data, which typically are collected in 15-minute intervals at U.S. Geological Survey (USGS) streamgages, as opposed to using the daily mean flow data. Likewise, during extremely low flows, the unit flow data may indicate short periods where streamflows reach levels detrimental to aquatic organisms.

- Comparing flow releases to unregulated conditions. Unregulated flows have been estimated by the U.S. Army Corps of Engineers (USACE) and USGS using a combination of pre-dam gage data and simulated unregulated flows (Risley, Wallick and others, 2010). Unregulated hydrographs and recession rates could be developed to represent environmental flow components under different climatic conditions. Flow thresholds associated with ecological objectives should be narrowly defined or refined to correspond to specific hydrogeomorphic and vegetation objectives and responses. For example, the Willamette SRP environmental flow recommendations describe bankfull discharge as a critical threshold for hydrogeomorphic and ecological processes. Currently, bankfull flood discharge is a regulatory flow determined by the USACE to minimize flood hazards (Keith Duffy, U.S. Army Corps of Engineers, written commun., 2011), and is smaller than the geomorphic definition of a bankfull event, which is statistically related to the 1.5-2-year recurrence interval flow event and occurs when flow overtops channel banks (Wolman and Miller, 1960; Risley, Wallick and others, 2010; Risley and others, 2012). Differences in terminology and flow magnitude could be clarified to better evaluate when a flow target is achieved and to ensure realistic objectives are associated with this threshold. 


\section{Appendix 3. Outstanding Research Questions and Additional Analyses to Support Refinement of Sustainable Rivers Project Goals}

The streamflow and ecological relations that are the basis for the environmental flow recommendations are currently not well defined for the Willamette River tributaries. In many cases, the existing flow-ecology relations (Gregory and others, 2007a; Risley, Wallick and others, 2010; Risley and others, 2012) are based on limited existing data, qualitative observations, and the best judgement of Sustainable Rivers Project (SRP) stakeholders. Limited understanding about flowecology relations could potentially hinder progress towards ecological goals defined by SRP stakeholder priorities. For example, some flow objectives may not be realistic, or some flow objectives could have negative effects on the riparian ecosystems they are intended to enhance. Addressing the following research questions will provide important data and information for refining the flow recommendations.

\section{Questions Related to Hydrogeomorphic Processes:}

- What is the floodplain area likely to be influenced by environmental flow releases? Delineating an "ecologically functional floodplain" would be helpful for defining the area where environmental flows will have the greatest influence on hydrogeomorphic and vegetation processes.

- What is the relation between streamflows and inundation patterns? More information is needed on the magnitude and duration of discharges necessary to support species and life stages, and the associated inundation patterns for these flows. For example, one SRP objective is to connect and support lateral aquatic habitats by inundating floodplain sloughs, but the discharge magnitude and optimal duration targets needed to inundate these areas are unknown. In addition to direct measurements, hydraulic models could be used to estimate the relation between flow and inundation. Habitat quality and availability studies would further support questions regarding duration and timing of seasonal flows needed to support various species and life stages.
- What is the flow necessary to trigger key geomorphic processes such as bed-material transport or erosion of floodplain forest? What are the geomorphically-effective flows for the study reaches? By documenting geomorphic responses to recent flows that meet the criteria for SRP bankfull, and small and large flood events, geomorphically effective flows can be determined to refine existing Willamette SRP flow targets with realistic outcomes for these flow events.

- What are the bed-material sediment characteristics in the study area? How do these relate to aquatic habitats? What is the relative balance between sediment supply and transport capacity for grain-size fractions that support specific habitats (for example spawning compared to rearing)? How might this relation change with different flows? What are the implications for current and future channel processes and habitat formation? For example, if a particular reach used for salmon or trout spawning has excess transport capacity for spawning-size gravels, and little inputs of new sediment from bank erosion or unregulated tributaries, it may be prone to losses in spawning habitats. Understanding these relations could inform flow management and potentially support other complementary management actions (for example, gravel augmentation) to support habitats prone to future losses.

-What is the timing of spawning and incubation, and what are the spawning site requirements (substrate, water temperatures, flow depths) in each of the reaches for spring Chinook salmon (Oncorhynchus tshawytscha) and other native aquatic fish species such as winter steelhead and rainbow trout (Oncorhynchus mykiss), and cutthroat trout (O. clarkii)? Much of this information is broadly known for spring Chinook salmon and winter steelhead, but better understanding variations within and between subbasins, across different years and flow regimes, and between different species would allow SRP stakeholders to better refine environmental flow releases to support successful spawning. 


\section{Questions Related to Vegetation Processes:}

- What are the key factors limiting vegetation recruitment? How can environmental flows address these limiting factors? Our understanding of these limiting factors is critical to setting pragmatic goals for floodplain forest regeneration. For example, if a particular reach lacks recruitment sites, then spring recession rates will not generate the desired response.

-What are the seasonal thresholds that support different stages of vegetation recruitment and succession? We currently lack a refined understanding of the flow conditions that support different life stages of native vegetation and how these flows vary along the length of each river. For example, spring recession rates are largely derived from the literature and have not been verified against local observations to determine if they are applicable to the Willamette study area.

- Is black cottonwood (Populus trichocarpa) a suitable indicator species for the Willamette SRP? Would vegetation guilds provide a better indicator of forest response to environmental flows? Using a guild approach would require new research to identify specific reaches where this strategy is needed and groups of species that share similar life histories and reproductive strategies, including non-native species that might out-compete native flora.

- What is the relative importance of vegetative root sprouts compared to seedling establishment for black cottonwood in the Willamette Valley? Initial research indicates that cloning by branch stem fragments could potentially be a robust pathway for black cottonwood regeneration (Jones and others, 2016). This process is not currently noted in the environmental flow recommendations. Further research is needed to determine the relative importance of vegetative and sexual reproduction of black cottonwoods (or other important indicator species), and further link seed and stem dispersal processes with streamflow characteristics.

\section{Additional Research and Analyses to Inform the Willamette Valley Sustainable Rivers Project Environmental Flow Program}

Datasets generated from monitoring activities also could be used to answer broader questions relating environmental flows, hydrogeomorphology, and vegetation and resulting patterns of habitat availability for different flows. These analyses would be beyond the scope of typical monitoring assessments to track implementation and effectiveness of the SRP program but would be critically useful for answering outstanding questions and setting realistic goals for SRP program. Examples of analyses and research to support the SRP include the following:

- Delineating the SRP river corridors into reaches according to channel type to provide a foundation for linking channel conditions with likely responses to different magnitude flows, realistic objectives for the SRP, and appropriate monitoring approaches for tracking progress towards SRP objectives. Because the comprehensive geomorphic studies that would support this classification are lacking for the SRP rivers, new studies are needed, spanning each river corridor between its upstream USACE dams and downstream confluence with the main-stem Willamette River. These studies would incorporate historical and recent assessments describing processes, patterns and rates of planimetric and vertical channel change, and likely future trajectories based on present-day factors such as sediment supply, bank erodibility, and physiography (for example, Knighton, 1998; Brierly and Fryirs, 2005). A major geomorphic study is currently underway for the Middle Fork Willamette River (Keith and others, 2017), and future studies could focus on the McKenzie, North, South and main-stem Santiam Rivers with a goal of developing a consistent framework for evaluating channel types across all of the SRP rivers (for example, Fitzpatrick and Knox, 2000; Surian and Rinaldi, 2003; Fitzpatrick, 2005; Rathburn and others 2009; Surian and others, 2009).

- Developing a bed-material sediment budget to assess relative balance between sediment supply and transport capacity for each river in the study area. The 
sediment budget is needed to better anticipate future hydrogeomorphic responses to different magnitude flows (for example, would certain flows trigger incision or reductions in bare bars?) and help SRP stakeholders to establish environmental flow targets that are aligned with present-day sediment supply (Wohl and others, 2015). A robust sediment balance quantifying spatial and temporal trends in variation in sediment supply and transport capacity would require a multi-faceted approach using hydraulic and sediment transport modeling (to characterize longitudinal trends in transport capacity for different settings and flow conditions) measurements of bed-material flux (to validate hydraulic modeling, and over time, develop relations between discharge and sediment transport), measurements of particle size and armoring ratios and morphological mapping (which together inform the modeling and each are useful indicators of sediment transport conditions; for example, O'Connor, 2014). Bed-material budgets for the SRP study rivers could be modeled after similar studies on the Chetco, Umpqua, Sandy, and North Fork Stillaguamish Rivers (Wallick and others, 2010, 2011; Major and others, 2012; Anderson and others, 2017).

- Conducting hydraulic modeling to assess how different magnitude flows influence vegetation recruitment. For example, modeling could be used to assess inundation patterns on unvegetated bars to determine optimal spring and summer flows to support seedling establishment. Likewise, model results from highflow scenarios could indicate velocities and shear stress distributions that could signify scour of young seedlings.

- Evaluating the relative importance of vegetative compared to sexual reproduction of black cottonwood in the Willamette study area and the environmental flow needs to support both pathways. Currently, much of the information on flow needs for cottonwood recruitment in the Willamette Valley is based on studies from the Midwest, where sexual reproduction of cottonwoods is the dominant mechanism for stand establishment, but previous studies in the Willamette Valley (Gregory and others, 2007a; Jones and others, 2016) suggests that vegetative propagules may be an important pathway for cottonwood recruitment. Additional research could help SRP stakeholders to understand the relative importance of both reproductive pathways and better determine the flow needs to support SRP goals for cottonwood recruitment. For example, if seedling reproduction is a strategy that SRP stakeholders want to support with environmental flows, future research on optimal recession rates could be prioritized because current SRP targets for spring transition flows based on studies from Midwestern streams (Mahoney and Rood, 1998) may be much different from suitable recession rates for the gravel-bed rivers of Willamette study area.

- Evaluating limiting habitats for different species, life stages, and seasons. Currently, there is little information describing reach-scale patterns of habitat availability for different aquatic and riparian species in the Willamette study area. Knowledge of key habitat limitations that are explicitly linked to certain species, flow conditions, and river reaches would help SRP stakeholders prioritize flow targets and the most appropriate monitoring strategies for measuring progress towards those targets. For example, hydraulic modeling coupled with habitat mapping could be carried out for each river corridor to determine spatial patterns of high-quality rearing habitat for spring Chinook salmon for different flow and stream temperature conditions. The resulting maps of habitat availability could be paired with discharge records to determine if some reaches lack habitats needed to support certain life stages at key times of the year. Once specific habitat limitations are identified in terms of flow, time of year, and spatial geography and underlying issue, flow management strategies can be developed to best address these limitations. 


\section{Appendix 4. Examples of Existing Datasets and Monitoring Efforts that Complement the Sustainable Rivers Project Monitoring Program}

There are multiple ongoing data collection efforts by other agencies and organizations that complement the monitoring approaches outlined in this document. To our knowledge, existing efforts would not be redundant with the activities described in this report, but rather could be used in conjunction with findings from these activities to evaluate ecological responses to environmental flows. Some examples of monitoring efforts that relate to the habitats and processes of interest to the Willamette Sustainable Rivers Project (SRP) are summarized here. This list is not exhaustive and could be re-evaluated when developing reach-specific monitoring plans. An approach for maximizing efficiencies between different agencies and groups is described by Podolak (2012).

1. Beginning in 2016, an interagency group (Science of the Willamette Instream Flow Team, or SWIFT) has been reviewing instream flow needs to support the Willamette River ecosystem (DeWeber, and others 2017). This group includes water managers from the U.S. Army Corps of Engineers (USACE), Oregon Water Resources Department (OWRD), Oregon Department of Fish and Wildlife (ODFW), and National Marine Fisheries Service (NMFS), together with scientists from ODFW, Oregon State University (OSU), University of Oregon (UO), and U.S. Geological Survey (USGS). Several studies to support flow management decisions commenced in summer 2016, focusing on instream flow needs for the main-stem Willamette River. The approaches and findings from these studies will inform environmental flow management throughout the Willamette River Basin.

2. The ODFW Oregon chub (Oregonicthys crameri) monitoring program collects data to evaluate the floodplain slough ecosystems used by Oregon chub. Data collection includes repeat surveys of water quality, bathymetry, water elevation, and fish communities at numerous sites throughout the study area (Bangs and others, 2015; 2016). These floodplain sloughs also provide habitat for other important species such as juvenile Chinook salmon (Oncorhynchus tshawytscha), red-legged frogs (Rana aurora), and western pond turtles (Actinemys marmorata). Because ODFW monitoring likely will continue through 2023, these sites could be logical places to establish permanent floodplain transects for monitoring environmental flows.
3. The ODFW Willamette Salmonid Research, Monitoring, and Evaluation Program evaluates juvenile life histories throughout the study area. The program periodically collects information on spawning sites, juvenile rearing habitats, and other information that complements the hydraulic, geomorphic, and vegetation monitoring strategies outlined in this framework. Future environmental flow research in the Willamette River Basin could aim to partner with ODFW to evaluate how fish are using habitats shaped by the environmental flow releases (Tom Friesen, Oregon Department of Fish and Wildlife, written commun., February 3, 2016). More information on this program is available at http:// oregonstate.edu/dept/ODFW/willamettesalmonidrme.

4. The USGS collects stream stage, flow, water quality, and temperature data at streamgages throughout the study area. Continuous temperature measurements are available for the streamgages in the study area (fig. 3-6; appendix 1). Turbidity, dissolved oxygen, $\mathrm{pH}$, and specific conductance are collected at select sites (http:// waterdata.usgs.gov/or/nwis/rt/).

5. The Nature Conservancy (TNC) monitors stream temperatures, native fish, vegetation, and other parameters at its Willamette Confluence Preserve on the Middle Fork Willamette River (floodplain kilometers 2-3). This site also has been used for other SRP monitoring (Jones and others, 2016) and has been identified as a high-priority monitoring zone for future studies.

6. The McKenzie River Trust oversees multiple properties along the McKenzie River and has baseline data on vegetation and habitat characteristics for these sites in addition to routine monitoring of site conditions. Because of their unique habitats and conservation status, these sites would make good candidates for long-term monitoring as part of the Willamette SRP (Jodi Lemmer, McKenzie River Trust, written commun., May 28, 2014).

7. The USACE collects stream stage data along the Middle Fork Willamette River to document water levels during high-flow events. Data generated from this program could be used to document the spatial pattern and magnitude of inundation associated with different magnitude flood events. Additional sites are periodically situated along other rivers (such as the North Santiam River) and may be added along other rivers in the future (Jim Burton, U.S. Army Corps of Engineers, written commun., May 23, 2014). 
8. Watershed councils in the Santiam, McKenzie, and Middle Fork Willamette Basins may have baseline information and ongoing monitoring data that could complement the Willamette SRP monitoring. Most of this monitoring is site-specific and may not coincide with the monitoring zones identified in this study. An example of potentially useful monitoring information collected by watershed councils is water quality, macroinvertebrate, and riparian vegetation data gathered in the Santiam Basin by the South Santiam Watershed Council (Eric Anderson, South Santiam Watershed Council, written commun., May 20,2014). Because watershed councils have in-depth knowledge of local habitat conditions and close working relations with landowners and resource agencies, they would be logical partners for future research and monitoring (Rebecca McCoun, North Santiam Watershed Council, oral commun., Oct 2, 2015).

9. The Biological Opinion developed for the Willamette River Basin Flood Control Project (National Marine Fisheries Service, 2008) specifies a comprehensive research monitoring and evaluation (RME) program to collect information needed for adaptive management of Endangered Species Act-listed fish populations and to track progress toward objectives specified in the Biological Opinion. RME is intended to "inform decisions regarding the effectiveness of mitigation measures in the Proposed Action and Reasonable and Prudent Alternatives, including alternatives for downstream flows and ramping, fish passage, water quality, hatchery program operations, habitat restoration and other measures" (National Marine Fisheries Service, 2008, p. 9-83). The studies conducted under the RME program are diverse, vary annually and are summarized annually at the USACE Willamette Fisheries Science Review. RME studies could complement and inform monitoring efforts of the SRP program.

10. Hydraulic models have been developed for several of the rivers in the study area that could be updated and used to inform the Willamette SRP. Models have been completed for the North Santiam River (Stonewall and Buccola, 2015), and the Middle Fork Willamette River (Ryan Kilgren, Tetra Tech, written commun., January 15, 2016). Additionally, models on shorter reaches have been developed for specific projects, such as for evaluating restoration alternatives at the Chahalpam site on the North Fork Santiam River (Troy Brandt, River Design Group, Inc., oral commun., January7,
2015). Models were developed to support specific flow scenarios and may need updates to assess various SRP flow targets (for example, low flows or high flow pulses), but existing models could serve as a starting point for evaluating inundation patterns.

11. There are multiple sources of site-scale surveys collected by organizations that would complement reach-scale repeat surveys described in this study. For example, the Oregon Department of Transportation conducts routine surveys and scour assessments at bridges in the study area. These cross-section surveys, conducted every 1-5 years, are useful for evaluating year-to-year changes in channel geometry (Jones, Keith, and others, 2012; Jones, O'Connor, and others, 2012a, 2012b). Other sources of information to evaluate incision and aggradation include surveys conducted to support ecological assessments, stream restoration, infrastructure, or flood mitigation. For example, on the Middle Fork Willamette River, ODFW has repeat surveys of numerous off-channel habitats (Brian Bangs, Oregon Department of Fish and Wildlife, written commun., February 2014) and TNC has surveyed bathymetry near their Willamette Confluence Preserve site. Other organizations and municipalities also could be contacted to build a dataset of existing surveys, which could be periodically updated and reviewed as new data are collected. However, a challenge with multiple sources of survey data is insuring that each dataset is referenced to a common vertical datum and meets standards for accuracy.

12. The Eugene Water and Electric Board has developed the Voluntary Incentive Program (VIP) to help protect drinking water quality in the McKenzie Watershed (http://www.eweb.org/sourceprotection/vip). The SRP and VIP monitoring programs share many common elements, and collaborative monitoring may allow for more efficient data collection for both programs (K. Morgenstern, Eugene Water and Electric Board, oral commun., April 2, 2015).

13. Changes in streambed elevation can be evaluated through specific gage analyses at USGS streamgages, whereby changes in water-surface elevation for a particular discharge can indicate incision or aggradation. Specific gage analyses for rivers described in this study originally were developed by Klingeman (1979) and updated by Wallick and others (2013). These analyses could be updated every $5-10$ years to determine trends. 
14. The OSU) and UO have a long-standing program to sample and assess native fish communities along the Willamette River and its floodplain. In summer 2015, the program was extended to three major tributaries downstream of USACE dams - the Middle Fork Willamette, McKenzie, and Santiam Rivers. Data from this research program can be viewed through the Willamette River Fish Database, which provides information on the abundance and locations of native and non-native fish species. At each sampling site, habitat conditions (including variables such as water depth, stream temperature, substrate, and riparian cover) are recorded and published in the database. Information from the database provides baseline data from which to measure changes resulting from environmental flows. The SRP monitoring program could partner with OSU to coordinate data collection activities to apply the relations between flows and geomorphic and vegetation responses to native fish communities (S. Gregory, Oregon State University, Department of Fisheries and Wildlife, written commun., February 5, 2016). Information on the fish communities is available in the Willamette Fish database (http://gis.nacse.org/wrfish/index.php).

15. The UO and OSU developed the SLICES framework as a spatial template for tracking changes in the floodplain of the main-stem Willamette River and its major westward-flowing tributaries (Gregory and Hulse, 2002). The spatial framework delineates the historical floodplain into a series of 1-kilometer $(\mathrm{km})$ transects orthogonal to the floodplain axis, providing a static template for tracking changes in the floodplain system. Each of these 1-km transects is then sub-divided into ten 100 -meter transects. To date, geographic information system coverages of floodplain forest cover, channel complexity, 2-year flood inundation, native fish richness, and salmon abundance, as well as cold water refuges, have been developed and overlain on the SLICES framework, and all datasets are publicly available through a web interface. As of early 2017, the SLICES framework is focused on the main-stem Willamette River (SLICES version 4 geodatabase, available at http://ise.uoregon.edu/slices/data.html, accessed July 24, 2017), but expansion of these datasets to the Middle Fork Willamette; McKenzie; and South, North, and main-stem Santiam Rivers will be completed in the future (D. Hulse, University of Oregon, Department of Landscape Architecture, written commun., July 17, 2017). SLICES, together with reach-scale maps of channel complexity and floodplain forest cover, would provide a spatial framework and geomorphic and vegetation baseline datasets for decadal status and trends monitoring. If a program is established to update SLICES datasets at decadal intervals, this effort could be executed in conjunction with the decadal-scale, reachwide mapping of floodplain vegetation and channel features proposed in this monitoring framework. The SLICES framework also could potentially be used to store and share some SRP spatial datasets. Because many SRP monitoring activities are closely aligned with the status and trends monitoring datasets housed in the SLICES framework, the SRP monitoring program could aim to coordinate data collection and mapping activities with the UO and OSU (D. Hulse, University of Oregon, Department of Landscape Architecture, written commun., February 5, 2016). More information is available at http://ise.uoregon.edu/slices/main.html.

16. The Confederated Tribes of the Grande Ronde manages more than 400 acres of land known as Chahalpam Wildlife Area on the North Santiam River for conservation. Several restoration-related activities are underway, including habitat, vegetation, fish, and wildlife surveys; ODFW chub research; and hydraulic measurements and modeling that are used to inform restoration strategies. The site has suitable geomorphic and vegetation characteristics, which make it an ideal candidate for future monitoring under the SRP program, and The Grande Ronde Tribe is supportive of future SRP research occurring at this site (Lawrence Schwabe, Confederated Tribes of the Grande Ronde, oral commun., August 27, 2014).

17. The Institute for Natural Resources has completed a pilot project to map riparian vegetation structure in the Willamette Valley from remotely sensed sources (J. Kagen, Institute for Natural Resources, written commun., October 9, 2017). Mapping riparian vegetation structure from aerial photographs and satellite data with the aid of lidar targeted several sub-watersheds in the Willamette Valley. Approaches to map composition were assessed but not fully developed for this pilot project. Similar approaches could be refined and implemented to monitor progress towards long-term SRP vegetation goals.

18. The U.S. Forest Service in coordination with local watershed councils has implemented large-scale restoration projects in the McKenzie and Middle Fork Willamette River Basins. Each project includes detailed monitoring plans which share similarities with the monitoring approaches described in this report. In particular, the monitoring program for the South Fork McKenzie River restoration site below Cougar Dam would provide a framework for tracking changes in physical habitat that could support restoration planning and evaluation, while also informing SRP and other flow management decisions at Cougar Dam. The South Fork McKenzie monitoring plans also provide useful examples for linking physical habitat characteristic with macroinvertebrate and fisheries monitoring $(\mathrm{K}$. Meyer, U.S. Forest Service, McKenzie Ranger District, September 25, 2018). 
Publishing support provided by the U.S. Geological Survey Science Publishing Network, Tacoma Publishing Service Center

For more information concerning the research in this report, contact the Director, Oregon Water Science Center

U.S. Geological Survey

2130 SW 5th Avenue

Portland, Oregon 97201

https://www.usgs.gov/centers/or-water 


\section{है}

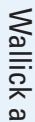

产

홓

商

产

居

:

롤

声

꽁

ิㅗ․

를

क्ष

일

꿏

田

空.

옹

$\stackrel{1}{1}$

要 